\title{
GADIR, SU ESTRUCTURA PLURAL.UN MODO DE VER SU FUNDACIÓN FENICIA EN EL ESPACIO Y EN EL TIEMPO
}

\author{
Gadir, its plural structure. A way to look at \\ the Phoenician foundation in space and in time
}

Diego Ruiz Mata

Catedrático de Prehistoria - Correspondiente de la RAH

Recibido: 31/05/2018

Revisado: 11/06/2018
Aceptado: $15 / 06 / 2018$

Publicado: 29/06/2018

\section{RESUMEN}

Los textos clásicos nos indican que los fenicios tirios fundaron Gadir en una isla frente a la costa cercana. En los extremos de la isla fundaron el templo de Melqart y la ciudad de Gadir. Lo que sucedió en el año 1100 a.C., ochenta años después de la caída y toma de Troya. Este mito se ha creído y aceptado durante siglos e incluso en la actualidad muchos mantienen esta fecha. Sin embargo, los datos arqueológicos de estos últimos años ofrecen otra visión más objetiva del espacio fundacional de Gadir y del tiempo en que se realizó. En cuanto a la fecha, la de 1100 a.C. no se ha comprobado y seguramente no se hará nunca. La datación más antigua de las primeras actividades y presencia fenicia en Occidente se hallan en los estratos profundos de la ciudad de Huelva, de la primera mitad del siglo IX a.C.. Y después, los fenicios fundaron en el mismo tiempo un pequeño establecimiento en la isla gaditana (TC), la ciudad fortificada del CDB (El Puerto de Santa María), en la desembocadura del rio Guadalete, y el templo de Melqart, en el extremo oriental de la isla. De este modo plural es como debemos ver el espacio que se ampara bajo el topónimo Gadir. Y el tiempo entre el siglo IX y VIII a.C.

Palabras Clave

Fenicios; Gadir; Bahía de Cádiz; Castilo de Doña Blanca; Cronología; Fundación de Gadir.
ABSTRACT

According to classical texts, Phoenicians from the city-state of Tyre found in the West, on a long island in front of the nearby coast, the city and a temple dedicated to Melqart -protector god of Tyre- at both ends. What happened in the year 1100 B.C., eighty years after the fall of Troy. This myth has been believed for centuries and even until a few years ago. The archaeological findings on the island of Cádiz and other point in the south of the Iberian Peninsula show more complexity and reality compared to written texts. The date of 1100 B.C. it can not be maintained and the foundation of the city must be located at the end of the 9th century B.C. or beginning of the 8th B.C. The Phoenician city was founded at the same time as Castillo de Doña Blanca (CDB) (El Puerto de Santa María, Cadiz), a fortified Phoenician city in the ancient mouth of the Guadalete River, and below the Sierra de San Cristóbal. On the other hand, the oldest Phoenician materials of the West has been founded in the current city of Huelva, dated in the second half of the 9th century B.C., decades before the foundation of Cadiz. We have to see the foundation of Gadir in this spacial mode and in this time.

KEY WORDS

Phoenicians; Gadir; Bay of Cádiz; Castillo de Doña Blanca; Chronologies; Foundation of Gadir. 
Todo Parecía EVIdente (GAdiR=CÁdiz - 1100 A.C) ${ }^{1}$

Aún en los comienzos de este siglo, la fundación fenicia de Gadir se reducía a hallar los restos arqueológicos en algún punto del islote menor, o Eritía, de los dos que componían las islas de Cádiz, y en el tiempo que señalaban las fuentes, hacia 1100 a.C., contemporánea de Utica, en la costa tunecina, y Lixus, en la de Marruecos. Las tres constituían las fundaciones más antiguas en los comienzos de la expansión semita por las aguas veleidosas, islas y costas del mar Mediterráneo y del Océano Atlántico. Cartago, con su carácter de origen político, religiosamente apartada en algún aspecto de la deidad protectora y ortodoxa tiria, e independiente de todas las fundaciones fenicias lejanas de las ciudades de la costa levantina, se fundó en el año 814 a.C., tres siglos posteriores a las mencionadas (Lancel, 1994). Mas una tradición procedente de Filistos de Siracusa, de mediados del siglo IV a.C., transmitía que la fundaron Azoros y Karkhedon, personajes tirios, hacia el 802 de Abraham, es decir, hacia 1215 a.C., anterior a las citadas (Frutos, 1987), en base a relatos griegos. Más credibilidad tuvo Timeo -300/250 a.C.- que se sirvió de fuentes fenicias y cartaginesas. $\mathrm{Y}$ un relato y mito narraron siglos más tarde -III d.C.- la historia de su origen (Justino XVIII, 4,4-6 y 9), que es la manera eficaz, de apariencia auténtica y robusta, de comenzar su andadura histórica en un punto elegido en el norte de África, lo suficiente lejos de Tiro, cercana de Utica poco antes fundada, y en una amplia costa para su control y expansión. El sentido político de esta fundación se manifiesta en el elenco categórico de los acompañantes en la salida de Tiro a tierras africanas de Elisa-Dido, hermana del rey Pigmalión y viuda del sacerdote de Astarté Acerbas, asesinado, compuesta de politai, ciudadanos, según Timeo, o de notables de alto rango, o senatores, según Justino (IV,15). $\mathrm{Y}$ en el aspecto religioso, donde tal vez resida el origen del problema, el dios Melqart no conservó el primer rango divino que poseía en Tiro, y su culto quedó relegado por el que formaban Tanit y $\mathrm{Ba}$ al Hammon. Este aspecto adquiere gran importancia, como todo lo relacionado con las creencias e ideología religiosa.

1 siglas empleadas en el texto:

Sierra de San Cristóbal (SSC)

Castillo de Doña Blanca (CDB)

Teatro Cómico (TC)

Cánovas del Castillo (CdC)

Calle Ancha (CA); Casa del Obispo (CdO)

Plaza de San Antonio (PSA)

Cerro del Castillo (CdCa)

Castillo de san Sebastián (CSS)

Torre de Tavira (TT).
Sin embargo, ambas ciudades no perdieron sus vínculos políticos y culturales y se relacionaban mediante una embajada anual que cada año partía de Cartago para la celebración de un sacrificio en el templo de Melqart de Tiro, el dios protector de la ciudad (Quinto Curcio IV,2,10), y el que navegó y acompañó a los fenicios tirios en sus procesos coloniales mediterráneos y atlánticos (Bunnens, 1979; Alvar y González, 1985; Aubet, 1993; Zamora, 2006; Tsirkin, 2013). La presencia de este dios en las navegaciones y fundaciones de colonias, factorías o templos era consustancial con estos acontecimientos, al representar la divinidad la propia ciudad de Tiro, la patria de la mayoría de los fenicios colonizadores, que simbólicamente también se desplazaba con ellos en la figura del dios, cuya esencia y vinculación perduraban lejos mediante su culto y los rituales. Es lo que se percibe en la fundación de Gadir y en otras muchas. La acción humana debe ir en compañía de la divina, en íntima conexión y dependencia absoluta, pues la religión es algo más que una creencia, son normas y conductas.

Junto a Tiro, Cartago es el segundo punto neurálgico político y económico en el amplio panorama colonizador semita del Mediterráneo. Y desde aquí, tuvo lugar la gran expansión por las costas norteafricanas e islas y costas del continente europeo en sus fachadas meridional mediterránea y atlántica a partir del siglo VI a.C. (Prados, 2001). Si en los inicios de la expansión fenicia, la ciudadEstado de Tiro fue la protagonista principal de esta acción colonial exitosa, en los comienzos del siglo VI a. C. -en 573 a.C.-, tras su caída política y económica con la conquista de Nabucodonosor, Cartago se erige como la regidora y sucesora del conjunto de todo este ámbito de control fenicio (Aubet, 1986;Rainey, 2004), ya orientalizado tras más de dos siglos, y al modo de un imperio militar y control comercial en estos mares hasta finales del siglo III a.C. en el que Roma vencedora, en su lucha con la gran Cartago perdedora, sucedió a la hegemonía secular cartaginesa de Occidente (Peralta, 2009). Lo que a continuación sucede es la historia de la conquista y expansión romana y la construcción de un nuevo mundo más helenizado y occidental. Ambos dominios, fenicios y romanos, y desde la alargada sombra de la cultura griega, crearon el ámbito de la Historia Antigua del Occidente, y las bases de su perduración, en sus aspectos esenciales (Pilkington, 2013; Riera, 2015). 
Este es el esquema general del panorama del primer milenio a. C. Son los detalles y ciertos puntos de su estructura lo que hay que precisar, donde se advierten las discrepancias más notables y las dudas justificadas entre los textos escritos y el documento arqueológico. Y no es novedad que así sucediera en una época de predominio del mito, de la voluntad divina, en los que se determinaron mediante historias inventadas o mitificadas los orígenes imaginados de estas fundaciones de ciudades y sus causas.

En esta activa historia mediterránea, y desde los siglos VIII-VI a.C., los griegos, colonizadores y competidores comerciales de los fenicios, van ocupando su espacio comercial y político con la fundación de colonias, convertidas pronto en ciudadesestados, en el centro del Mediterráneo, en el sur de la península italiana y en la estratégica y bien situada isla de Sicilia (Domínguez, 1993 y 2014). En el extremo occidental del Mediterráneo se fundaron Masalia-Marsella-, en la costa francesa (Bats, 2012), y Emporion -Ampurias-(Oller, 2013), en Gerona. Son los dos núcleos-ciudades comerciales más importantes de la actividad colonizadora griega occidental. En la costa hispana, bajo el control fenicio, no se han hallado hasta ahora fundaciones griegas, pese al intento de la búsqueda de Mainake en algún punto de la costa mediterránea malagueña (Niemeyer, 1979; Rodríguez, 2002; Sarmentero, 2015), sin éxito. Pero se advierten desde Málaga a Huelva contactos comerciales directos, continuos y de distinta intensidad durante casi todo el siglo VI a.C. (Cabrera, 1990 y 1995; González de Canales y Llompart, 2017), y una actividad comercial más extensa durante todo el siglo IV a.C. por la costa mediterránea y suroeste atlántico peninsular (Cabrera, 1994 y 1998).

Y en este contexto, surge en Occidente el topónimo de Tartesos, con sus mitos, reyes y fuentes, su realidad tangible arqueológica y su significado histórico y de riquezas relacionadas con la plata. Es el primer reino hispano del que hablan las fuentes griegas desde al menos finales del siglo VII a.C., cuyo emplazamiento se discute, e incluso su existencia como ciudad o un amplio territorio. Constituye la primera referencia histórica conocida desde las costas orientales mediterráneas a la inmensidad del Océano Atlántico. A ello se refieren las fuentes escritas en sus parcas y crípticas alusiones (Blázquez, 1969).

Éste es el marco básico en el que el investigador se ha movido durante años y aún lo hace en ciertos aspectos. Y todo parecía evidente, demasiado claro y escueto. Mas las excavaciones efectuadas en estos últimos decenios, en la costa malagueña, Huelva, CDB, Cádiz y en otros poblados del Bajo Guadalquivir, más un estudio más intenso del territorio, han modificado de modo notable la historia de los momentos más antiguos fenicios, entendida desde las fuentes grecorromanas, acomodadas en un soporte demasiado frágil e inseguro arqueológico.

Gadir-Cádiz y la fecha fundacional de 1100 a.C. deben ser revisadas, vistas de modo más amplio, desde su realidad arqueológica actual y de la ciudad que la fundó, que cuenta ahora con estratigrafía de extraordinario interés como referencia (Bikai, 1978) y una necrópolis de la Edad del Hierro-Al-Bass- (Núñez, 2011) , que han deparado un conjunto suficiente de materiales para su contrastación detallada con los asentamientos de Occidente. Y en conjunto, los inicios de la colonización hasta el extremo atlántico. Sólo ha bastado con comenzar a remover la tierra, profundizar en sus estratos más profundos, hallar restos de viviendas de ciudades o necrópolis y recoger materiales, para lo que era evidente e inmutable, se torne en conocimientos más creíbles y parecidos a la realidad que debió ser, comprensión al enjuiciarlos y cierta transparencia. Es lo que pretendo.

LO QUE LOS TEXTOS TRANSMITEN Y LOS QUE SE HAN PERDIDO.

No es mucho lo que transmiten. Se refieren a los hechos fundacionales, inmersos en el arraigo de los mitos más que en la historia real, a fechas también mitificadas donde la guerra y caída de la ciudad de Troya, y la autoridad de Homero, son sus fuentes de referencias, creíbles e inmutables, sin nada concreto que lo certifique. Pero la mayor parte de estos vínculos son de épocas recientes, muchos siglos después de haber sucedido los hechos, interpretadas a su modo y conveniencia, siempre bajo la autoridad de otro autor más antiguo que, a su vez, había recurrido al mismo sistema de apoyo y referencia. Y desde la visión del griego Estrabón, pero escritor en época romana en los inicios del imperio, y sirviéndose de antiguas noticias, autores y bibliografías, conocemos más de la Bahía gaditana de su tiempo y de los pretéritos. No de modo objetivo, sino con la pluma dirigida y enderezada desde el poder, desde la derrota de Cartago, desde el surgimiento de Roma como el gran imperio que comenzaba. 
Se debe al geógrafo Estrabón un conocimiento de Cádiz y de la Bahía considerable, e igual del estuario aledaño del Guadalquivir, transformado en su época, y de sus núcleos urbanos. Pero la arqueología ha proporcionado en estos últimos años respuestas a las preguntas de la fundación de Cádiz, su sentido político, económico y espacial y a la datación más precisa de su fundación.

Como lo que pretendo es que nos situemos en el tiempo sólo de las fuentes griegas y romanas y en el ámbito de Cádiz, para más tarde contrastarlo con el espacio de los datos arqueológicos, comencemos con el texto de Estrabón (III,5,5), que recogió de Posidonio de Apamea (Siria) (135 - 51 a.C.), sobre la fundación de la ciudad fenicia gaditana y en templo de Melqart. El texto es conocido y relata la historia de la fundación de Gadir tras dos intentos fallidos en Sexi-Ex, en el Mediterráneo, y en Onoba, en el extremo Atlántico. Hasta aquí el relato, coherente y explicado. Y en realidad lo es, salvo en cuestiones puntuales que no modifican mucho el proceso fundacional de Gadir. Lo sustancial está aquí reflejado: las primeras navegaciones y la fundación de Cádiz tras varios intentos, como resultado de un conocimiento empírico de unas costas que desconocían y de las que seguramente tenían sólo vagas referencias de navegantes previos. Lo que importa son los detalles.

Pero ¿cuándo sucedió esto?. Veleyo Partérculo (19 a.C.-31 d.C.), en su "Historia de Roma" $(1,2,3)$, hacia el año 30 d.C., responde a la pregunta: “... ochenta años después de la guerra de Troya...y en aquel tiempo -se refiere a la entrada de los dorios en el Peloponeso- la escuadra tiria, la más poderosa en el mar, en la región más alejada de España, en el extremo del mundo conocido, fundó Cádiz en una isla rodeada por el océano próxima al continente y separada de él por un estrecho. Pocos años después, los mismos fundaron Utica en África”. La fecha se relaciona con el retorno de los Heráclidas, una de las estirpes griegas -los dorios-, años después de finalizada la guerra troyana, tradicionalmente situada en el año 1184 a.C. Lo que significa que Gadir se fundó, según la tradición y el mito, en 1104 a.C.

En cuanto al templo, Plinio (N.H., XVI, 40; $\mathrm{XIX)}$ cree que el de Lixus era poco más antiguo que el de Gadir. Y menciona también al de Utica: "Memorable también es el templo de Apolo en Utica donde aún se encuentran las vigas de cedro puestas cuando la fundación de la ciudad, hace 1178 años”. Según el cómputo de su tiempo, el 77 d.C., la fecha fundacional de Utica sería la del 1101 a.C. La obsesión por el tiempo, en el sentido de situar el hito preciso del comienzo, ha sido siempre un tema humano y recurrente en la historia de muchas ciudades. Es un hecho necesario. No hay sociedad sin historia y referencias ancestrales de su origen, lo que requiere un tiempo y su concepto, y una historia mítica que lo acompaña y un héroe fundador en el caso griego, que constituya el origen de una estirpe.

La Guerra de Troya, transmitida por Homero, marcó en la mentalidad del mundo griego, el inicio de la historia mediterránea y occidental, al menos en lo que atañe a las fundaciones occidentales fenicias. Y Estrabón, cuyo texto sobre Iberia es el más extenso y detallado conocido, se basa en documentos de autores más antiguos, que menciona, y en Posidonio quien visitó el país a inicios del siglo I a.C.. Una época ya romana, una costa transformada y una estructura poblacional que poco se parecía a la de la época fenicia y púnica. Por esa época, Tartesos ya reposaba en la memoria, en unos pocos textos griegos y en la interpretación de unos mitos arcaicos que también debieron sobrevivir en el recuerdo. Conocemos cómo la memoria histórica se puede emplear a beneficio de quien la usa manipulada, de cómo se deforma, miente o se destruye. Si hubo más textos sobre Tartesos y los tartesios, han desaparecido a lo largo de los siglos. En este contexto, escuálido de documentos, Estrabón escribe su libro III dedicado a Iberia, basado en autores más antiguos, cuyas obras se han perdido o muy parcialmente conservadas en otros. Hay que creer, pues, en la veracidad de sus fuentes, a las referidas a las más antiguas de la protohistoria, con la cautela de las historias conservadas mediante los mitos. Y Estrabón lo hace $(I, 3,2)$ transmitiendo que la fundación de Gadir tuvo lugar poco después de la guerra de Troya, cita recogida de Eratóstenes, situado entre el 280 y 195 a.C. Y en otro pasaje $(I I I, 2,13)$ añade que "las primeras noticias fueron debidas a los fenicios, que dueños de la mayor parte de Iberia y de Libia desde antes de la época de Homero, quedaron en posesión de estas regiones hasta la destrucción de su hegemonía por los romanos”. Escribe, además, que "la expedición de Herakles y la de los fenicios a estos parajes le dieron (a Homero), de sus habitantes la idea de un pueblo rico y de buena condición...”. Los datos son griegos. No hay ninguno fenicio. 
En suma, fueron tres las colonias fenicias más antiguas -Gadir, Utica y Lixus-, junto a sus templos de Melqart, como corresponde a la ciudad-estado de Tiro protegida por esa divinidad; en segundo lugar, su datación relacionada con la Guerra de Troya, entre 1101 y 1104 a.C. Las tres colonias, muy distantes, marcan el amplio espacio de la colonización de oriente a occidente y seguramente también los centros nucleares políticos más determinantes y de mayor importancia en la primera fase colonial. Se percibe que las fuentes son griegas, al mencionarse Troya como hito cronológico, y el afán de aunar las hazañas de Heracles, asimilado a Melqart, con las expediciones fenicias y la referencia al templo de Apolo en Utica que guardaba las vigas de cedro del momento fundacional de la ciudad. En los textos de autores griegos hay un interés de atar a héroes y dioses griegos con las hazañas fenicias, sin importar demasiado la precisión del tiempo. Lo que a veces deja confuso al investigador.

Sobre las fundaciones de estas ciudades y su cronología tan antigua, que conducen prácticamente a un Bronce Tardío, se han esgrimido opiniones en defensa de las antiguas fechas, pese a la inexistencia de documentos urbanos y de materiales de ese momento. A lo que se une la ecuación Tarsis bíblica-Tartessos en Occidente, en tiempos de Salomón e Hiram de Tiro, cuyas relaciones comerciales y constructivas -el primer templo de Jerusalén- se databan en torno al 1000 a.C.(González de Canales 2004; González de Canales et al., 2010). Este año sugería rutas y viajes previos, constatados en época micénica (Martín de la Cruz, 1988; Ruiz-Gálvez, 2009). Y los que defendían la fecha de los textos usaban como pretexto la antigüedad supuesta de unas figurillas, como la del Sacerdote de Cádiz o Ptah, que databan en fechas muy antiguas, como prueba explícita de esos viajes, y que en la actualidad se sitúa en siglos posteriores, en el VIII a.C. probablemente (Quintero, 1928; Jiménez , 2002).

Lo que los textos transmiten, a veces, es un elenco de confusiones, de hipótesis que se amparan en débiles argumentos y contradicciones con los restos arqueológicos de estos últimos años, reflejados en miles de folios impresos. E insistimos en la carencia de fuentes fenicias para su contrastación. De ello fue consciente García y Bellido (1968), conocedor de los textos. Advierte de la pobre información que poseemos de lo que pensaban los fenicios y griegos de la Península Ibérica, de la escasez de textos que nos han llegado, y del interés sobre todo comercial que debió prevalecer en las informaciones sobre estos países desconocidos. Y de la validez de muchas informaciones, obtenidas a veces de boca en boca en los puertos y de las experiencias, exageradas o inventadas, de los marineros. Un panorama desolador de la información escrita, con mucha frecuencia tardía, de escaso rigor geográfico o histórico, y transmitida según sus intereses e interpretaciones de los hechos por griegos y romanos. El términos parecidos se expresa Javier de Hoz (1989) sobre las fuentes de Tartesos y Gadir. Y, según Momigliano (1984), el conocimiento erudito y las curiosidades de los intelectuales sobre las ciencias humanas en general, antes del helenismo, eran muy diferentes a las nuestras. La traducción de los textos no implica necesariamente su comprensión.

Poco después, y en base a la fundación de Cádiz y a las fundaciones en general, M. E. Aubet (1994) lo expresó bien hace unos años en estos párrafos: "La tendencia helenística a ennoblecer el origen de algunas ciudades de Occidente, su obsesión por las fechas fijas (como la de la caída de Troya) y la sobrevaloración de Homero como fuente histórica, hace que se confundan en una sola varias tradiciones relativas al extremo occidente y se ajusten las cronologías a la época de los héroes homéricos. Así, confundiendo realidad histórica, ficción y pseudoerudicción, el deseo de ensalzar los viajes al remoto occidente en la mitología hace que la historiografía helenística buscara héroes epónimos fundadores de colonias". Un resumen perfecto que me ahorra un análisis más detallado. Se parte de la base de la invención mítica de la fecha, necesaria para la elaboración del inicio de un relato histórico y a incorporar Grecia, mediante Heracles asimilado a Melqart, a la historia de Occidente.

Si las fuentes no esclarecen las preguntas que la investigación demanda, e incluso confunden y conducen por vías complejas o equivocadas, debe ser la arqueología la que ilumine con sus propios datos materiales. Pero la arqueología tiene sus límites y no siempre puede contestar a todo lo que se demanda. En el caso gaditano, se ha necesitado mucho tiempo, y el azar, para regalarnos las primeras respuestas a los temas básicos de la ubicación de su espacio fundacional y del tiempo en que sucedió. Mas lo esperado, por escasa información de las fuentes, no es exactamente lo que los estratos arqueológicos y los materiales han puesto a disposición del investigador. El mito transforma lo real, lo encubre y lo conduce a los dioses, y a su voluntad. 
Sin ESPACIO NO HAY HISTORIA, SÓLO MITO Y POESÍA. (Figuras 1 y 2).

El paisaje que hoy se contempla, desde el templo de Melqart a las islas gaditanas y desembocadura del río Guadalete, al que hay que incluir necesariamente el amplio estuario del Guadalquivir hasta la actual Sevilla, la antigua Spal fenicia, ha variado morfológicamente con el tiempo en estos últimos cinco mil años. Lo suficiente para que no se ajusten, a nuestros ojos actuales, las masas de agua dulce, salada y de tierra desde los inicios del milenio I a.C. hasta época romana, y desde Roma hasta hoy. Analizar la visión del pasado protohistórico y los textos con la mirada del presente es un método equivocado que conduce a la confusión y al desatino, a una geografía que en muchos aspectos no se corresponde con la actual.

El medio actual, si comenzamos desde Sevilla a Sanlúcar de Barrameda, donde el Guadalquivir desemboca, y desde aquí a Cádiz y poco más lejos hasta el islote de Sancti Petri, ha cambiado notablemente hasta la actualidad, pero con más rapidez hasta los tiempos romanos (Gavala y Laborde, 1927, 1928). El recorrido no es largo, pero los aspectos acuáticos, de tierra y poblaciones han sufrido una transformación importante. Poco tienen que ver con los paisajes que los marineros acostumbraban a navegar. Y para pergeñar el antiguo medio fenicio incidiremos

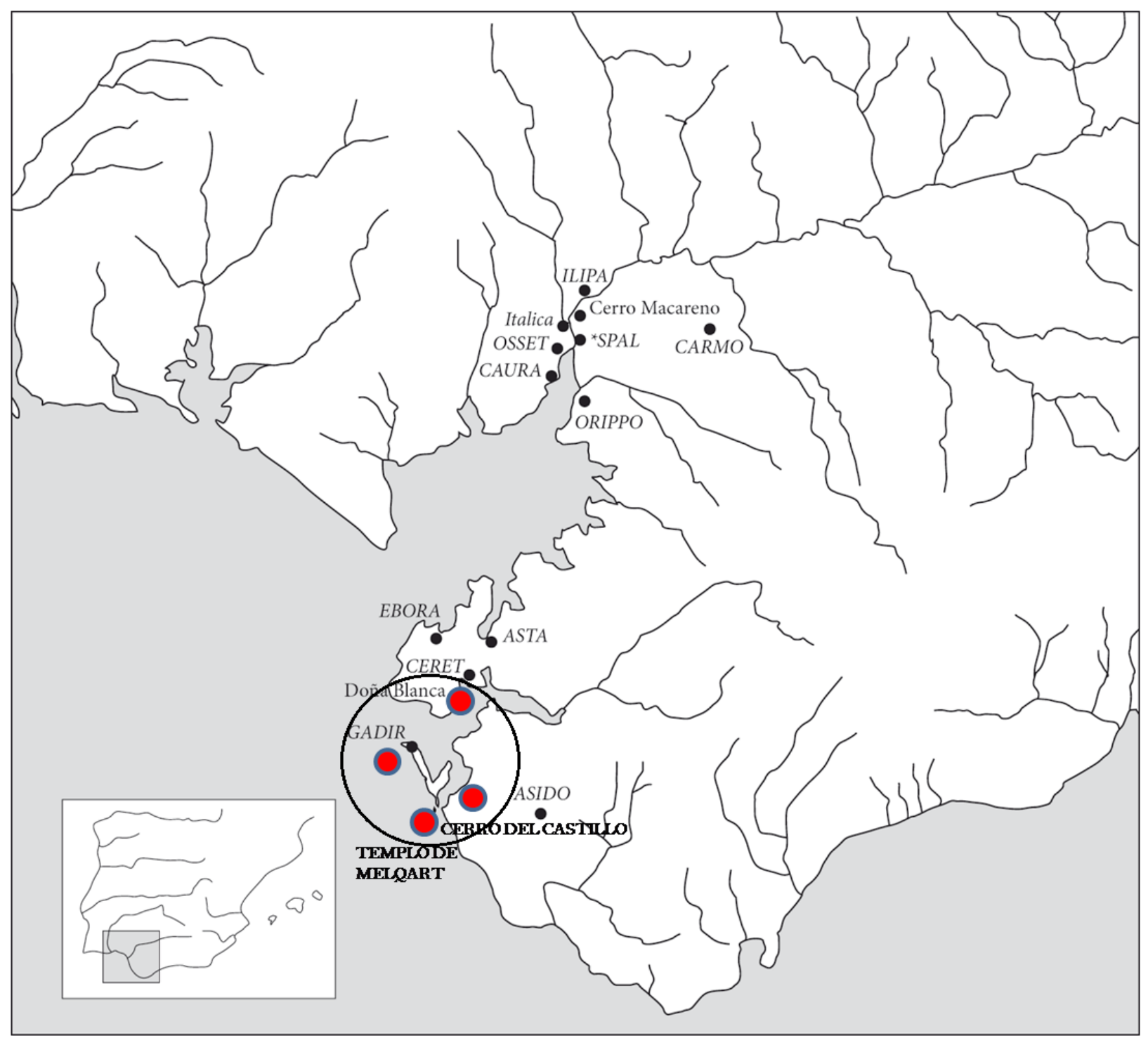

Figura 1. La geografía de los fenicios hacia el año 1000 a.C. en la Bahía de Cádiz y estuario del río Guadalquivir. Los puntos rojos corresponden a las fundaciones arcaicas fenicias en la Bahía. 


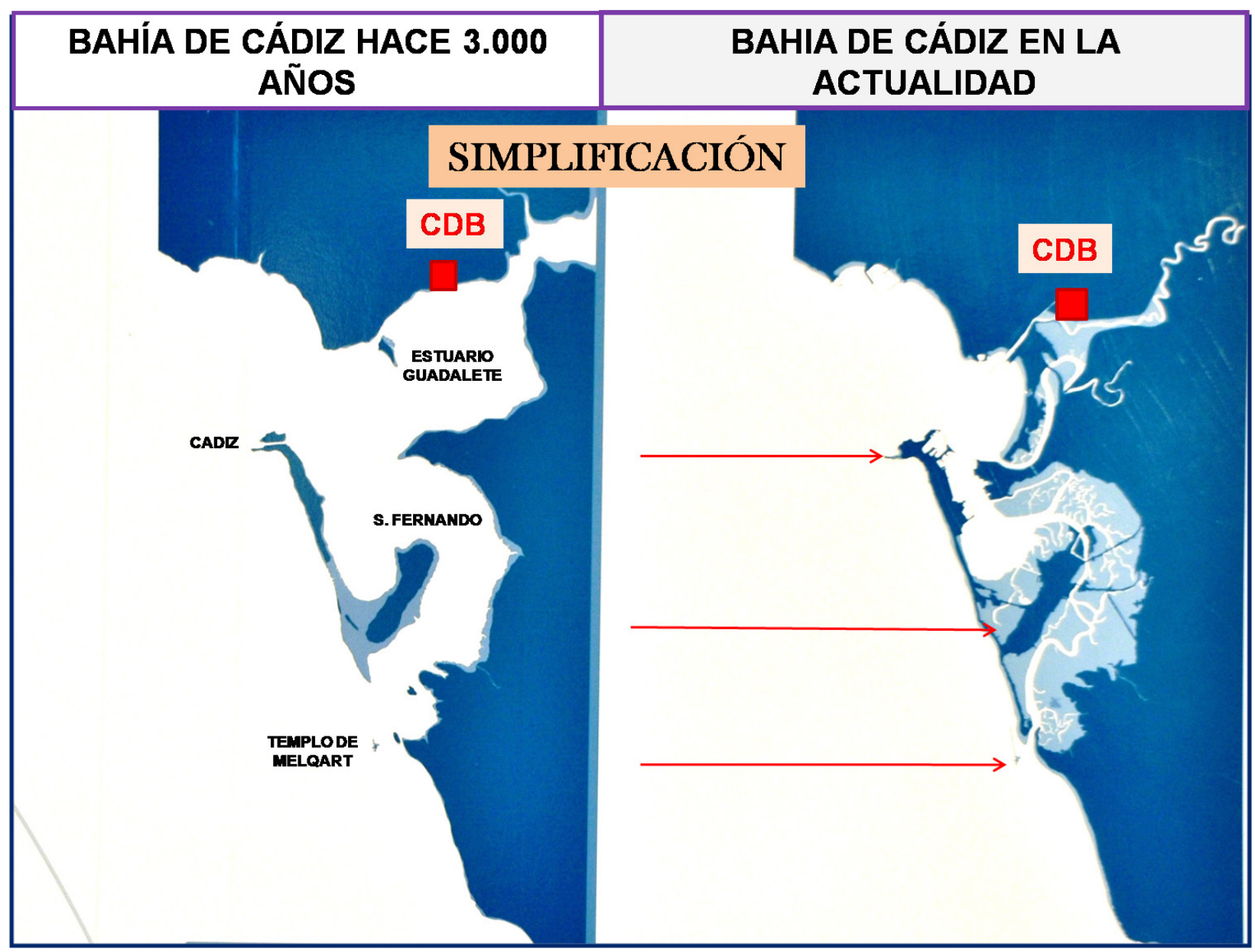

Figura 2. La Bahía a la llegada de los fenicios y en la actualidad.

en los puntos esenciales, aquellos que fueron relevantes para su ocupación y navegación, y donde se instalaron puertos y puntos comerciales.

Primero, el estuario del Guadalquivir, cuyo paisaje consiste actualmente en lagunas pequeñas en extensión, marismas, arenas y zonas más firmes, por donde discurre un río no muy ancho que ha permitido navegarlo desde época romana hasta la actualidad. La desembocadura la sitúan en las cercanías de Coria del Río, próxima a Sevilla, seguramente en tiempos fenicios (Gavala y Laborde, 1936, 1949 y 1952; Menanteau, 1976 y1978; Abad, 1975), pero trabajos más recientes la llevan poco más arriba, al este de Alcalá del Río, durante el Neolítico final e inicios de la Edad del Cobre -6500 BP (Arteaga et al., 2016; Barragan, 2016). Se ha detectado, además, que la costa alcanzaba hasta la falda de Valencina de la Concepción, en el Aljarafe sevillano. Y también en el pié de la colina donde se instaló el centro cultual del Carambolo (Fernández y Rodríguez, 2005), dedicado a Astarté, protectora de los navegantes, se ha detectado posibilidades de la existencia de un puerto, como cabía esperar por su situación, su función como centro religioso y el desarrollo de un activo comercio, como se advierte en las numerosas ánforas (Carriazo, 1973). También se ha identificado un puerto en la ciudad romana de Itálica, que debió permanecer activo hasta los siglos I y II d.C. (Arteaga et al., 2015). Y se ha delimitado asimismo, a nivel de hipótesis y con cautela, debido a la complejidad que ofrece la ciudad, la línea de costa del máximo flandriense en el casco urbano de la ciudad de Sevilla-Spal (Barragán, 2016). Sevilla debió ser un conjunto de alturas en lo que actualmente es el centro de la ciudad, riachuelos, agua y marismas. Y desde aquí hasta el Aljarafe debió ofrecer un paisaje similar (Escacena y García, 2012). 
En la zona oriental del estuario, y posteriormente laguna, se abrían esteros o abras navegables. Estrabón se fija en ellos y los describe con precisión, pues comprende su importancia para la navegación y sus ventajas para la intensa ocupación humana (III,2,4). Es obvio que Estrabón transmite lo que los esteros son, en su aspecto geográfico, y cómo propiciaron el comercio. Pero en época fenicia, que es la que interesa aquí, estas ventajas debieron ser las mismas. Lo que se advierte en la ocupación de los esteros, de los bordes del estuario y de su desembocadura a la altura de Sevilla. Junto a ellos se materializó un núcleo de población, debido a las posibilidades de navegación y a las riquezas agrícolas, ganaderas y mineras de su entorno. Así lo describe Estrabón (III,2,3). En cuanto a los asentamientos al borde de los esteros, indica Estrabón que "los indígenas, conocedores de la naturaleza de la región, y sabiendo que los esteros pueden servir lo mismo que los ríos, han construido sus ciudades y poblados sobre aquellos, tal como lo hacen en la ribera de los ríos” (III,2,5). Y los romanos aprovecharon estas circunstancias. Son los casos, por ejemplo, de Mesas de Asta, que tuvo un importante núcleo protohistórico, como advierten los estratos de la ciudad y su extensa necrópolis (González y Ruiz Mata, 1999), o Lebrija y su amplia secuencia estratigráfica. Antes de llegar a Sevilla, Caura (Coria del Río), que debió poseer un puerto de gran tráfico comercial (Escacena, 2001). Y Sevilla fue un núcleo importante (Campos, 1986; Escacena, 2012), llamada Spal y que tenía enfrente el grandioso centro ceremonial de El Carambolo (Fernández, 2007).

La Bahía de Cádiz, en el 3000 B.P., en la época de las primeras navegaciones a esa zona, eran dos islas de diferentes tamaños, la menor Eritia, el núcleo actual del casco urbano y la mayor Cotinusa, separadas en torno al $6500 \mathrm{BP}$ y unidas después mediante una aglomeración arenosa, formándose así dos puertos (Arteaga et al., 2001). En este estudio geoarqueológico de la isla de Cádiz, que reconstruye las antiguas líneas de la costa y su interior, desde el 3500 a.C. hasta el 1000 a.C., la época aproximada de la fundación y primeras actividades fenicias, muestra que en la época más antigua había dos islas separadas mediante un canal (Ponce, 1985; Ramírez, 1982), conocido como "Canal Bahía-Caleta”, y que parece más bien una vía del mar abierta desde la zona de la Bahía. La hipótesis del canal se basaba sobre todo en las curvas de nivel. Pero había que comprobar su existencia. Lo que constituyó la razón y finalidad del proyecto geoarqueológico. En términos generales, las perforaciones efectuadas permitieron precisar que las curvas de nivel no explicaban la existencia de un canal, sino más bien una colmatación de un estrecho marino situado entre ambas islas.

Más tarde, hacia el 1000 a.C., el canal quedó cegado en su tramo intermedio, lo que causó la formación de dos ensenadas, una abierta a las aguas del océano expuesta a las erosiones marinas y otra hacia la Bahía, de aguas más tranquilas, que creó una serie de sedimentos arenosos que unieron Cádiz con San Fernando. Las ensenadas permitieron la navegación y sirvieron como puertos. La de la Bahía debió ser más profunda y permitir la navegación de barcos, según el criterio de los geólogos. Lo más probable que fuese el puerto principal de la ciudad fenicia, más resguardada de los vientos y vendavales. Y al parecer, en este lugar cerrado, en los estratos de las perforaciones realizadas se han hallado materiales escasos de los siglos IX y VIII a.C., lo que probaría que estuvo abierto en los primeros siglos fenicios (Figura 3).

En suma, en tiempos fenicios, ambas islas, estaban unidas por un denso cordón que formaban dos ensenadas. La más utilizada, por sus posición más favorable a los azotes del mar y los vientos fue la que miraba a la Bahía. En cuando a la topografía, las excavaciones del TC han revelado la existencia de una colina pequeña y muy baja, que alcanzaría $6 \mathrm{~m}$ sobre el nivel del mar y bajaba hacia la ensenada-puerto. Fue aquí donde tuvo lugar la fundación fenicias a finales del siglo IX a.C. e inicios del VIII a.C. El templo de Melqart, fundado al mismo tiempo que la ciudad, según Estrabón -lo lógico y probable-, asentaba sobre un islote, posiblemente más amplio que el actual. La figuras 2 y 3 reflejan la Bahía e islas en el tiempo de la fundación fenicia. Enfrente, la SSC, la desembocadura del Guadalete y el CDB. Y por detrás, la amplia campiña de gran riqueza agropecuaria.

La ARQueología EN CÁdiz ANTES DEL AÑo 2000.

En 1999 publiqué un trabajo titulado 'La fundación de Gadir y el Castillo de Doña Blanca: contrastación textual y arqueológica" en el que abordaba uno de los temas más debatidos, matizados y con un gran número de páginas ya publicadas que dejan sin resolver el lugar donde se edificaron las primeras casas fenicias y la fecha en que se hicieron. $Y$ ante estos vacíos, que había que explicar de algún modo, 


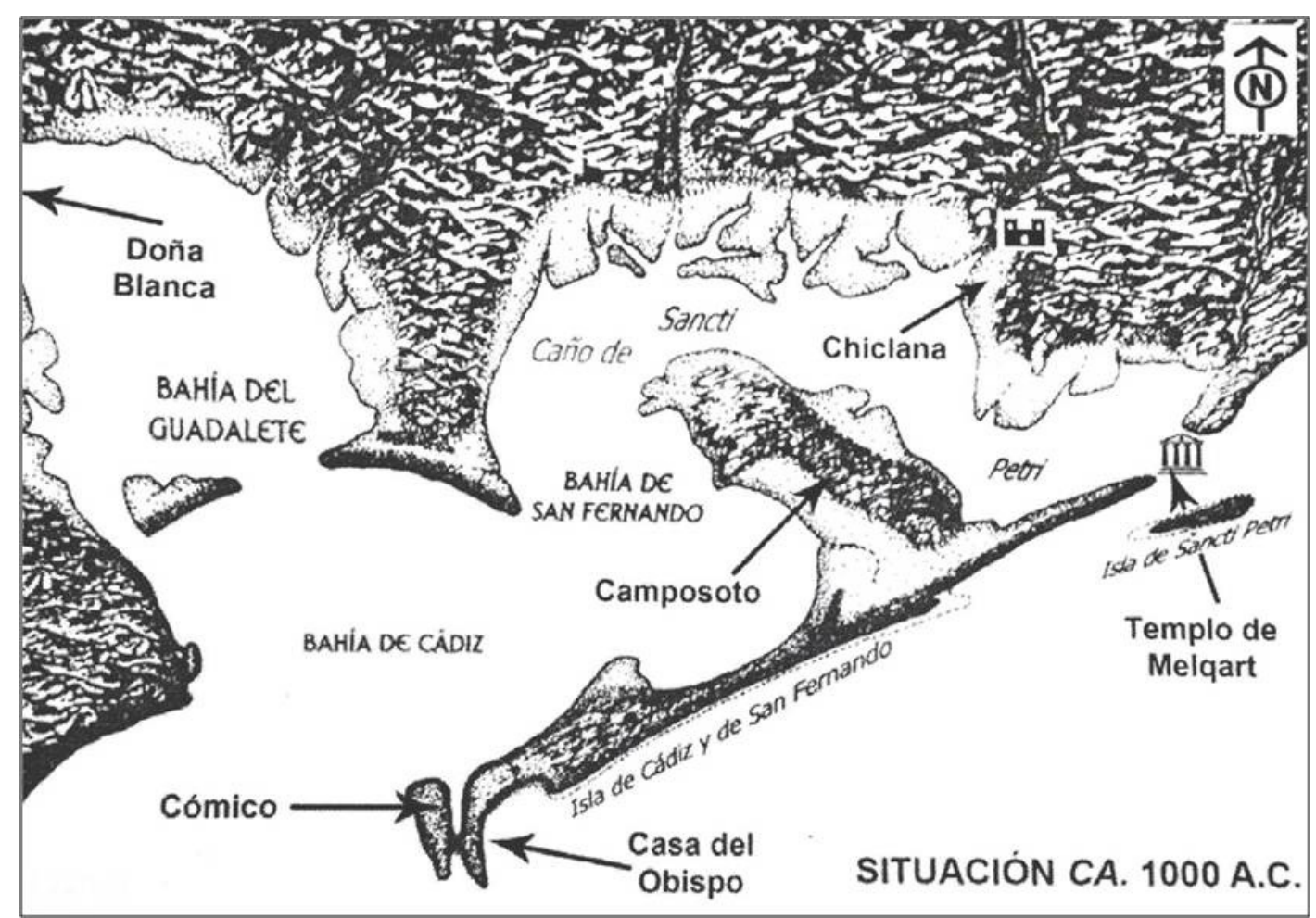

Figura 3. Interpretación de la Bahía de Cádiz, hacia el año 1000 a.C., tras las investigaciones geológicas (Según Arteaga et al.).

señalé la posibilidad de la pluralidad fundacional, valorando el $\mathrm{CDB}$ en el acto fundacional.

Hasta ese año, 1999, no había evidencias arqueológicas que mostrasen dónde se hallaban los restos de la antigua ciudad fenicia, pese a las excavaciones realizadas en los primeros decenios del siglo XX, debidas a P. Quintero. En cambio, se exhumaban enterramientos desde el siglo VI a.C. hasta época romana (v.v.a.a., 2010). Mas hay que advertir que se habían hallado desde 1887 -fecha de hallazgo del sarcófago antropoide-, de modo esporádico y casual, piezas arqueológicas de gran valor intrínseco e histórico pero sin contextos, que sugerían claramente la importancia de la isla fenicia-púnica. Ninguna de ellas se aproximaba a la antigua fecha de 1100 a.C. Hacia el año 2000, la notoriedad histórica de Cádiz, considerada la primera fundación fenicia en occidente, no se correspondía con la escasez de hallazgos de materiales arcaicos y la inexistencia siquiera de una vivienda fenicia que hubiese alumbrado lo que los textos indicaban y los investigadores buscaban con ahínco en sus entrañas y paciencia, pero sin éxito.

Me voy a centrar, de modo resumido, en dos aspectos: en la mención y valoración de algunos de los hallazgos de gran relevancia arqueológica, propios de lugares de importancia, y en el esbozo de las hipótesis sobre la ubicación de la ciudad, según la topografía y las fuentes. En 1887 se halló el sarcófago antropoide masculino, considerado como el primer punto de partida de las investigaciones fenicias y púnicas en España, y desde luego en Cádiz (Almagro-Gorbea et al., 2010).. Años más tarde se hallaron cistas e hipogeos púnicos en esa zona (Quintero, 1912; Jiménez, 1971). Casi cien años después, en 1980, se halló un segundo sarcófago, femenino en esta ocasión (Blanco y Corzo, 1981), y su contexto pudo determinarse con más detalles, mas tampoco ha aportado demasiado del carácter y significado sacro del lugar y su entorno Se data años poco antes del masculino, en torno al 460 a.C. (Almagro-Gorbea et al., 2010). Quizás un estudio detallado de sus entornos y contextos hubiesen explicado sin dudas sus significados, como enterramientos destacados de una necrópolis o como monumento en un lugar sagrado, similar al hallado en el entorno de la Casa del Obispo (Gener et al., 2014) . En cualquier caso, son dos piezas importadas, cuyo origen se discute pero que tienen sus prototipos en la misma costa fenicia (Mustafa, 2013, 2014, 2015 y 2016; Frede, 2000), 
y que expresan simbolismos que son por ahora un enigma. Tales enterramientos son ejemplos de poder y prestigio de la isla gaditana, pero sus significados se escurren y oscurecen al carecer de contexto espacial y de inmersión en el ámbito de una ciudad cuya estructura desconocemos por completo.

Sucede igual con la figurilla de bronce con su rostro cubierto con una máscara de oro, hallada por sorpresa en 1928 en el curso de unos trabajos en la CA, Edificio Telefónica, a una profundidad difícil de precisar bajo el suelo actual (Quintero, 1928; Blázquez, 1975; Jiménez, 2002). Se ignora el contexto exacto en el que se halló. Pero se ha transmitido que fue junto a unos vasos cerámicos a torno, perdidos (Ruiz Mata, Pérez y Gómez, 2014). Si es cierto, debió pertenecer al enterramiento de un sacerdote, o de un personaje religioso o sacerdote. Y se ha dudado también de si se trata de un sacerdote, poco probable, o del dios Ptah, deidad creadora del panteón egipcio, inventor de la albañilería y protector de los artesanos y de los arquitectos. A muy pocos metros del lugar de este hallazgo, se excavó un pozo ritual de bastante profundidad, del que recogieron dos betilos en el fondo, y restos en superficie de celebraciones de banquetes. Quienes estudiaron y publicaron los resultados de la excavación (Ruiz et al., 2014), técnicamente precisa y muy rigurosa, hallan una relación entre pozo y posible enterramiento, o acaso se trata de una acción ritual en los mismos inicios de la fundación de la ciudad fenicia. Este lugar se halla cerca de la pequeña ciudad semita en el TC.

De modo también casual se halló en 1958 un capitel protoeólico (Gruben, 1963; Lipinski, 1984; Marín y Jiménez, 2011; Marín, 2014), al parecer en los acantilados que rodean al CSS. Es aquí donde se sitúa el Kronion, o templo de Kronos. No es improbable que este capitel, árbol de la vida, que cabalgaba sobre el fuste de una columna, con carácter simbólico y sin función de carga en un entablamento, flanquease con otra similar la entrada de un templo in antis. Recientes excavaciones han exhumado restos fenicios y cerámicas muy arrasados por el tiempo y el abandono (Maya et al., 2014) en el solar del CSS donde pudo estar el templo de Kronos. Hay quienes dataron en los siglos VIII-VII (Lipinski, 1984) o más tarde, en los siglos VI-V (Gruben, 1963). En la costa del Levante mediterráneo es frecuente su uso en la arquitectura religiosa de Israel (Kletter, Ziffer y Zwickel 2015), $\mathrm{y}$ se datan sus comienzos entre los siglos X y IX
a.C., creyéndolos inventados por los ómridas, pero en el norte de Israel se sitúan en los siglos IX y VIII a.C. El templo de Salomón estaba precedido por dos columnas, flanqueando la entrada, con capiteles de volutas, palmetas o árboles de la vida (Tuzi, 2002; Mccullough, 2007; Apple, 2014). Y existen numerosas capillitas de arcilla, como ofrendas, cuyas entradas están precedidas por este par de fustes y capiteles simbólicos (Kletter, Ziffer y Zwiekel, 2015). No hay dudas de que este capitel gaditano estaba situado en la entrada de un templo semita.

Estas piezas junto a otras menores, (Blázquez, 1975), de fechas dudosas, han sido los elementos que han servido de argumentos para confirmar la antigüedad e importancia de las islas gaditanas. Pero la ciudad continuaba oculta en algún punto de la isla Eritía. En 1997 se publicó un artículo(Muñoz, 19951996) que trataba del asentamiento fenicio y púnico de Cádiz y esboza una secuencia crono-espacial tras varios años de investigaciones, la primera síntesis que conocimos y agradecimos por aquellos años de escasez de datos arcaicos. Comienza el trabajo en los siglos VIII-VII a.C., época fenicia arcaica que "resulta aún hoy poco conocida” (Muñoz, 995-1996, 79), pues "no son muchos los datos arqueológicos de que disponemos, pero sin embargo, el panorama no es tan negativo como recientemente han argumentado algunos investigadores". Se refiere a lo que argumentamos sobre el CDB y Cádiz en 1995 y a las quejas de las carencia de urbanismo y de estratos con materiales arcaicos (Ruiz Mata y Pérez, 1995). Y a continuación, muestra las diferentes hipótesis de la situación del lugar del primer asentamiento fenicio, bien en la plataforma rocosa del Castillo de Santa Catalina y la Punta de la Nao (Corzo, 1983), que no se ha confirmado, o en la Torre de Tavira, como cree este autor, sencillamente por razones estratégicas y porque en sus alrededores ha habido algún hallazgo que no prueba nada, o en una tercera opción en el barrio de Santa María (Álvarez, 1993), donde se halló un nivel de habitación, ciertamente dudoso, con materiales del siglo VII a.C. Esto es lo que teníamos, a fines del siglo XX, para afrontar el arduo e importante tema de la primitiva ciudad fenicia. Muy poca cosa todavía en esos años. Y seguí expectante, consciente de que estos datos sólo eran breves destellos que no resolvían los problemas de la fundación de Gadir.

De ahí pasa a unos cuantos materiales recogidos en la zona, datados en el siglo VI a.C. (Múñoz, 1995-1996, p. 81-82), que se alejan del tiempo histó- 
rico que interesa en este trabajo. Y sobre las necrópolis manifiesta que "en estos primeros momentos (siglo VIII y primera mitad del siglo VII a.C.), no tenemos datos arqueológicos seguros que nos confirmen su ubicación y características tipológicas". No obstante, y como justificación, que no era precisa, pues no siempre se halla lo que se busca, señala la existencia de un oinócoe protoático, datado en la primera mitad del siglo VII a.C., y de procedencia muy dudosa -tal vez no de Cádiz, sino traído de fuera en época moderna por algún viajero coleccionista (Ruiz Mata, 1999, 296-7), y de un sello signatario del siglo VIII-VII a.C., que se halla en el Museo Arqueológico Nacional (Marín, 1983), y se creyó de mayor antigüedad.

Aquí he de hacer un breve inciso y mencionar, siquiera someramente, el conjunto de tumbas del siglo VI a.C., que corresponde a uno de los lugares de enterramiento de la isla gaditana, incluyendo a ambas. Son las más antiguas encontradas en Cádiz hasta el momento. Se hallaron en la isla mayor -Kotinoussa-, en su comienzo, y en el camino conducente al templo de Melqart. En una área amplia, se exhumaron 19 tumbas de incineración, y otras más tardías, de los siglos V y IV a. C,.(Perdigones, Muñoz y Pisano 1990). Corresponden casi todas a cremaciones in situ en fosas simples o dobles. Y han proporcionado notables piezas de adorno de oro.

$\mathrm{Y}$ de regreso a las apreciaciones anteriores, el autor alude a un conjunto de piezas de gran interés halladas en la Punta del Nao, que debe corresponder a ofrendas del templo de Astarté que se situaba en ese lugar y halladas en el agua (Ramírez y Mateos, 1985). Y además, se refiere a un pyxis, sin contexto, pero procedente de la playa de Santa María (García, 2005), con una forma prototípica micénica y que perdura hasta los siglos VII y VI a.C. en el Próximo Oriente (Muñoz, 1995-1996, 81). Por los atributos y decoración parece ser del momento tardío.

El expresivo artículo "La Grande Cadici dei Fenici”, de S. Moscati, de 1995.

Con motivo del Homenaje al prof. Bondí (Ruiz Mata, 2016), acudí a un artículo escueto pero explícito, publicado por S. Moscati en 1996 (Moscati, 1996), escrito seguramente muy poco antes. En el año 1995, la fecha posible de la redacción del artículo, se había celebrado en la ciudad de Cádiz el IV CIEFYP, una época, casi un decenio, de gran interés por los proyectos sistemáticos de investigación llevados a cabo en Andalucía desde 1984, año en el que se transfirieron las competencias en arqueología y se desarrolló una importante y sistemática actividad arqueológica.

Lo más significativo de este artículo, que aporta mucho y por ello lo utilizo como representativo del momento, es que mantenía los mismos supuestos para el concepto de Cádiz que años atrás, salvo la adición a esta metrópolis de la ciudad del CDB, donde se habían realizado numerosas campañas de trabajo entre 1979 y 1992 (Ruiz Mata y Pérez, 1995). Y en lo que ataña a Cádiz y a Huelva, aún no se habían exhumado los restos más antiguos fenicios gaditanos del TC (Gener et al., 2014), ni los hallados bajo los niveles freáticos en la zona más baja de los cabezos (González de Canales, 2004). Pero el CDB nos había regalado, en su potente estratigrafía, las claves que barajo en la comprensión de la estructura fundacional fenicia en la Bahía. Aún no se valoraba, pese al reconocimiento de muchos investigadores y de los datos exhumados, su importancia en el proyecto fenicio de la fundación de Gadir y las consecuencias en el desarrollo espacial, político, cultural y económico de la Bahía y del suroeste peninsular, en la creencia de la unicidad fundacional. El artículo de 1999 incidió en este aspecto y en las contradicciones y desajustes textuales y arqueológicos sobre el problema fundacional gaditano, pero faltaban las manifestaciones que probasen mis argumentos. Todo llegó poco más tarde, en los comienzos del siglo XXI, cuando se realizaron excavaciones en el entorno de la TT - en el TC-, el punto topográfico más alto, y en otras zonas del casco antiguo de la ciudad (Figuras 5, 14 y 15).

Moscati, en su artículo poco extenso pero detallado y directo, expone los siguientes puntos básicos, que compendiaban lo que muchos investigadores opinaban como él sobre la fundación de Gadir y su importancia en Occidente: 1) Gadir forma parte de la trilogía, con Lixus y Utica, más antigua fundada en Occidente, hacia 1100 a.C.; 2) tales fundaciones, y en especial la de Gadir, se efectuaron en razón del control de la producción de oro, estaño y plata para su comercio con Oriente; 3) la datación en relación a la caída de Troya, como mantenían las fuentes, pese a que ni en Cádiz ni en Lixus, en la costa marroquí, (Aranegui et al., 2011; Maass-Lindemann, 1992; Habibi, 1992)) se habían exhumado materiales anteriores al siglo VIII a.C. ; 4) al CDB -conocido por entonces de modo superficial- situado en le desembocadura del río Guadalete y frente a Cádiz, lo consideraba de importancia excepcional 
desde los comienzos del siglo VIII a.C., pero "si rivela dunque, in funzione di Cadice -la negrita es mía-, come il grande porto di imbarco e sbarco delle merci provenienti dall'entroterra o inoltrate verso l'entroterra stesso"; más adelante alude a su amplia estratigrafía, en torno a 9 m., a sus casas, murallas y cronología; y en el apartado 3.3 (Moscati, 1996, 16), contrasta Cádiz-CDB con la hipótesis, casi un supuesto lógico, en su opinión, que "si tale era la consistenza del centro evidentemente subordinato del Castillo de Doña Blanca, benché tuttora in maggior parte sepolta, ancor piú rilevante doveva esserne la funzione, a cui si subordonava evidentemente il complesso portuale alla foce del Guadalete”. En suma, en la isla de Cádiz se fundó la ciudad fenicia de Gadir, en un punto de Eritia, y enfrente, en la desembocadura del río Guadalete, se estableció el puerto para las importaciones y exportaciones. Este fue el esquema explicativo de Cádiz y CDB: un ciudad en la isla y un puerto en la costa, sin considerar las características de cada lugar, sólo el concepto que dimanaba de las fuentes. Poco más tarde se advirtió la inconsistencia de este punto de vista, o la falta de una perspectiva más amplia.

Por aquella época, se habían efectuado numerosas excavaciones en la ciudad de Huelva, en la zona minera de Riotinto -Cerro Salomón- (Blanco, Luzón y Ruiz, 1969 y 1970), en el poblado metalúrgico de San Bartolomé (Almonte) (Ruiz Mata, 1981 y 1989; Ruiz Mata y Fernández, 1987) y en otros puntos onubenses de la campiña, que proporcionaron datos explícitos que avalaba su importancia en época protohistórica, en los primeros siglos del milenio I a.C. y la posibilidad de la existencia en los cabezos onubenses de la ciudad de Tartesos o uno de sus núcleos más importantes (Gómez, 1996). Por ello, Moscati destaca su importancia, por las evidencias arqueológicas -casos de la necrópolis de La Joya (Garrido y Orta, 1970; Garrido y Orta, 1978)-, el cabezo de San Pedro (Blázquez et al., 1979; Ruiz Mata et al., 1981) y las excavaciones efectuadas por el Servicio de Arqueología de la Diputación onubense (Fernández, 1990), y del importante núcleo minero de explotación de plata y las informaciones de Herodoto $(1,163)$ sobre las navegaciones griegas foceas y jonias, en época de Argantonio -supuesto "rey" tartésico-, desde fines del siglo VII y la mayor parte del VI a.C.

$\mathrm{Y}$ aunque considera Moscati la importancia de otros asentamientos, defiende la indiscutible primacía de Cádiz, su función de ciudad nuclear en el contexto político y económico de la expansión fenicia en la Península Ibérica y el Atlántico africano. Sin embargo, reconoce que su Cádiz descrita -"La Grande Cadice dei Fenici"- era sólo su visión suya particular, compartida con otros investigadores, que requería razones arqueológicas tangibles y valoraciones contrastadas. No se equivocaba.

Ésta es la visión generalizada en 1995, que me motivó a repensar el tema y valorar desde el inicio fenicio en la Bahía gaditana el sentido, función y cronología de la fundación del CDB. Una ciudad de su extensión, fortificada con una potente muralla desde los inicios del siglo VIII a.C., a la que sucedieron otras dos - en los siglos V/IV y III a.C.-, y una potencia estratigráfica de casi $9 \mathrm{~m}$, no podía quedar relegada sólo a un mero apéndice de Cádiz en tierra firme, a su exclusiva función de puerto y zona portuaria dependiente y subordinada, teniendo Cádiz posibilidades físicas de poseerlo sin requerir el del CDB. La geoarqueología, poco más tarde, mostró la existencia de un puerto bastante importante, resguardado de los vientos y de gran calado para las embarcaciones de comercio (Arteaga et al., 2001). La explicación debía ser otra y las funciones de ambos puntos también. Y el caso de Huelva, del que aquí sólo se ha mencionado algún aspecto, requería más análisis, como se manifestó diez años después, con hallazgos que han abierto nuevas perspectivas a los viejos problemas que se han mantenido a la expectativa durante largo tiempo.

El Congreso de 1995, celebrado en Cádiz, no aportó demasiados datos al tema de la fundación de Gadir y a la fecha del inicio de las actividades en Cádiz y en la Bahía. No obstante, las campañas de excavaciones en el CDB habían despertado serias dudas sobre el momento y la realidad de la fundación de Gadir. ¿Cómo esta ciudad había quedado olvidada en las fuentes grecorromanas?. Y ¿cómo la investigación no había reparado en ella como una fundación fenicia contemporánea a la de Cádiz y valorado más su situación de independencia en la estructura política y socio-económica?. La perspectiva con la que se analizaba el CDB quedada obnubilada por la tradición y las parcas y oscuras fuentes. La arqueología en la isla había ofrecido retazos de su importancia, piezas desgajadas -los casos del sarcófago antropoide de Punta de Vaca, el llamado Sacerdote de Cádiz o Ptah de la CA-, pero no en sus manifestaciones urbanas de sus momentos más antiguos. El urbanismo es lo que caracteriza a la ciudad y la valora. Y faltaba el elemento principal. 
Más explícitos han sido los comentarios de otros investigadores, y conocedores excelentes de la arqueología gaditana (Frutos y Muñoz, 2008, 239). $\mathrm{Y}$ sus sensatas opiniones que reproduzco: "Como se ha comentado anteriormente, la falta de proyectos de investigación sistemáticos en la ciudad de Cádiz han contribuido sin duda a la génesis de una información arqueológica irregular, sesgada, vinculada al azar y con grandes desequilibrios, al estar abordada desde las necesidades de investigación en función del desarrollo urbanístico. Esto ha provocado, p. ej., que los trabajos en las necrópolis fenicia, púnica y romana, como consecuencia de la expansión urbanística de la ciudad en los años sesenta y setenta hacia la zona de Extramuros hayan sido muy numerosas, en detrimento de las supuestas áreas urbanas, coincidentes con el casco histórico, donde debido a la escasa movilidad urbanística, las intervenciones han sido más bien parcas (...)”.

"A esta circunstancia hay que añadir la disparidad de métodos y sistemas de registros empleados por los numerosos profesionales de la Arqueología que han excavado y excavan en la ciudad. Como consecuencia un gran cúmulo de datos y materiales que difícilmente podrán clarificarse si no se aborda su estudio desde planteamientos científicos, lejos del matiz "mercantilista" que preside buena parte de las excavaciones actuales en nuestras ciudades". No les faltaba razón.

La cuestión es que poco se ha avanzado en estos últimos años, casi veinticinco. La universidad no tiene a la investigación arqueológica como prioridad, los avances son muy lentos, reiterativos en los mismos temas, y las esperanzas de progreso son cada vez menores y poco estimulantes. Si la investigación pende siempre de un hilo y del azar, al socaire de las actividades de urgencia, por imperativo legal, que el arqueólogo no elige y tampoco el tiempo de su ejecución, sólo la suerte puede deparar un hallazgo que produzca un beneficio científico a un tema detenido y durmiente. La investigación no puede depender del azar. Tiene que programar.

\section{LA ARQUEOLOGÍA EN ACCIÓN Y LOS CAMBIOS CONCEP-} TUALES DE LO EVIDENTE.

En los años de la época dorada de las excavaciones sistemáticas y continuadas en el Bajo Guadalquivir y Huelva se ha avanzado mucho en los estudios del territorio y en asentamientos claves para la comprensión de la secuencia de la protohistoria del Suroeste. Lo que sucedió en la década de los ochenta -1984- y los años de inicio de los noventa, poco menos de diez años. Y constituyó un tiempo de investigación activo para la ampliación del campo de conocimiento en el estudio del territorio, poco practicado hasta entonces, en las excavaciones sistemáticas de yacimientos claves por su importancia arqueológica e histórica, y excavaciones de urgencia en puntos y períodos relevantes -prácticamente inexistentes hasta este momento-, que han favorecido conocer aspectos nuevos y esenciales de Huelva (Gómez y Campos, 2001; Fernández, 1990), Bajo Guadalquivir y Bahía de Cádiz (Ruiz Mata, 1994 y 1998; Frutos y Muñoz, 2008; Niveau de Villedary, 2008, 2010 y 2014). Los autores citados ofrecen un panorama adecuado y real de la historiografía arqueológica del suroeste. Las fuentes escritas, sin olvidarlas, quedaron relegadas a un segundo plano, pero expectantes, porque siempre se espera confrontarlas.

Pero antes habían emergido hallazgos importantes, desde los inicios de los años sesenta (Ruiz Mata, 1998), y dos años antes con el hallazgo inesperado del tesoro del Carambolo (Carriazo, 1973), el fondo de cabaña donde se halló y el "poblado bajo". Las cerámicas del Carambolo, consideradas tartésicas por su excavador, propiciaron el inicio del conocimiento real de la sociedad del Bronce Final en el suroeste y sus materiales. Los comienzos de la década fueron fructíferos en excavaciones de ciudades y necrópolis fenicias, que hasta ahora se desconocían. Son los casos de la necrópolis Laurita de Almuñécar (Granada) (Pellicer, 1963), y las factorías de la costa mediterránea malagueña -Toscanos (Schubart, 1984), Morro de Mezquitilla (Schubart y MaassLindemann, 2017) y Cerro del Villar (Aubet et al. ,1999)-, que dieron a conocer la realidad de un asentamiento fenicio, sea cual fuese su función, estructuras de viviendas y tipos cerámicos, procedencias y cronologías. En el área onubense, se comenzó a excavar en los cabezos, donde se suponía que se habían instalados sus primeros habitantes protohistóricos. Y la necrópolis de La Joya (Garrido y Orta, 1970 y 1978), supuso un hallazgo y excavación trascendente para adentrarnos, a través de sus muertos y ajuares, en la realidad social y religiosa de las sociedades autóctonas orientalizadas. Y comprobar con éxito arqueológico la existencia de la extracción y beneficio de plata en la zona minera de Riotinto, que constituyó el principal de los incentivos fenicios en los primeros contactos occidentales. Lo que quedó reflejado en el V Symposium Internacional de 
Prehistoria Peninsular, organizado por el prof. Maluquer de Motes y celebrado en 1968 en Jerez, con un notable resultado por las informaciones nuevas aportadas, conducentes a un camino muy favorable para penetrar en el corazón de las fuentes y de la realidad arqueológica. Estos avances no se habían alcanzado aún a la Bahía gaditana. Habría que esperar unos años todavía con el comienzo de los trabajos arqueológicos en el CDB.

Las bases de investigación sobre los fenicios estaban en gran parte establecidas a inicios de los setenta, salvo en el caso gaditano. A partir de esta década se continuó excavando en los sitios que he mencionado y en poblados del Bronce final, a los que se prestó más atención (Ruiz Mata, 1982). En Andalucía Occidental, y en Huelva, el Cabezo de San Pedro centró la atención de la investigación, al proporcionar la estratigrafía del Bronce Final más importante de las conocidas en la ciudad (Blázquez et al., 1970 y 1979; Ruiz Mata et al., 1981). Y otra de sus aportaciones fue la constatación del comercio foceo tras la deseada plata tartésica (Cabrera, 1990), mencionado por Herodoto (IV, 154: I,163). En la producción de plata, las excavaciones de San Bartolomé en Almonte manifestaron la existencia de un poblado metalúrgico en exclusividad, dedicado a su beneficio (Ruiz Mata, 1981 y 1989). No debió ser el único, en la red, o network, de la extracción, producción y comercio de la plata. Lo que conforma un panorama de una industria primaria compleja desde la tecnología y política comercial. Y en esta época, en la Bahía gaditana, comencé a dirigir, desde 1979, las excavaciones en el CDB (El Puerto de Santa María), la ciudad fenicia más importante del suroeste (Ruiz Mata y Pérez, 1995). Con esta investigación se inició en la zona una etapa que cambió mucho de los esquemas teóricos sobre la fundación de Gadir-Cádiz, sus motivos y su constitución política y económica. De ello hablaré más adelante.

En el término de El Puerto de Santa María, además de las excavaciones pioneras en el CDB, y bajo su impulso y resultados, se han realizado estudios de territorio en la costa y en la campiña (López et al., 1996). Y el Museo de Jerez investigó el poblamiento de las zonas próximas al antiguo estuario del Guadalquivir, donde se hallaron numerosos puntos protohistóricos (González y Ruiz Mata, 1999). En cuanto a excavaciones arqueológicas, hay que mencionar las de Campillo (López et al., 1996), Las Beatillas en la Sierra de San Cristóbal (Ruiz et al., 1990) y Pocito Chico (Ruiz y López, 2002;
Ruiz et al., 2004), en la Laguna del Gallo. Lo que ha proporcionado un conocimiento necesario de la ocupación indígena y sus relaciones con los fenicios que habitaban el CDB.

En esta fase de la investigación, hay que destacar que desde el inicio de la década de los ochenta se han efectuado numerosos trabajos, en el contexto de la geografía humana, relacionados con el territorio y su poblamiento, vías de comunicación y comercio e intensificación en la captación y producción de recursos, conducentes al análisis de las estructuras sociales. Y se ha ido elaborando el mapa poblacional de las diversas etapas de la protohistoria, que sería prolijo y tal vez inoportuno detallar. A lo que se unen excavaciones importantes en diversos lugares nucleares, casos de Carmona (Belén et al., 2014), Sevilla (Campos, 1986), Cerro Macareno (Pellicer et al., 1983), Coria del Río, la antigua Caura (Escacena, 2001), Montemolín (De La Bandera et al., 1995) y otros más en el área gaditana.

Las excavaciones sistemáticas, de urgencia, estudios de territorios y analíticas, produjeron un salto cuantitativo y cualitativo de datos para abordar con criterios más objetivos y rigurosos lo que significó la colonización fenicia en Occidente, los procesos de interacción e integración entre las sociedades semitas y autóctonas y la debatida cuestión tartésica. Y en este amplio contexto, la fundación de Cádiz, que en modo alguno fue el resultado de la casualidad, sino un proyecto meditado.

El giro Sustancial de LA BAHÍA EN LOS PRIMERos AÑOS DEL SIGLO XXI.

Cuando S. Moscati definía su "Grande Cadici dei Fenici”, en 1996 -y lo menciono por su significado e hito historiográfico-, Cádiz no había deparado datos de interés de su época inicial arcaica. Y reflejaba lo que pensaban muchos investigadores. Cádiz era el centro fenicio de la Bahía, indiscutible, e irradiaba hacia la costa e interior mediante el CDB. Quedaban sin explicar cuál fue el papel del templo de Melqart, su relación con la ciudad y el entorno inmediato, y qué significaba la ciudad del CDB en este entramado político, religioso y económico. No podía ser sólo un punto en el mapa de la geografía fenicia, una ciudad y un puerto de apoyo de la metrópolis de la isla. La arqueología conduce a otra valoración distinta en muchos aspectos.

La Cádiz arcaica, la de sus primeros momentos, ha ido adquiriendo significado por medio de las excavaciones efectuadas en $\mathrm{CdC}, \mathrm{CdO}$, TC y CA. Por 


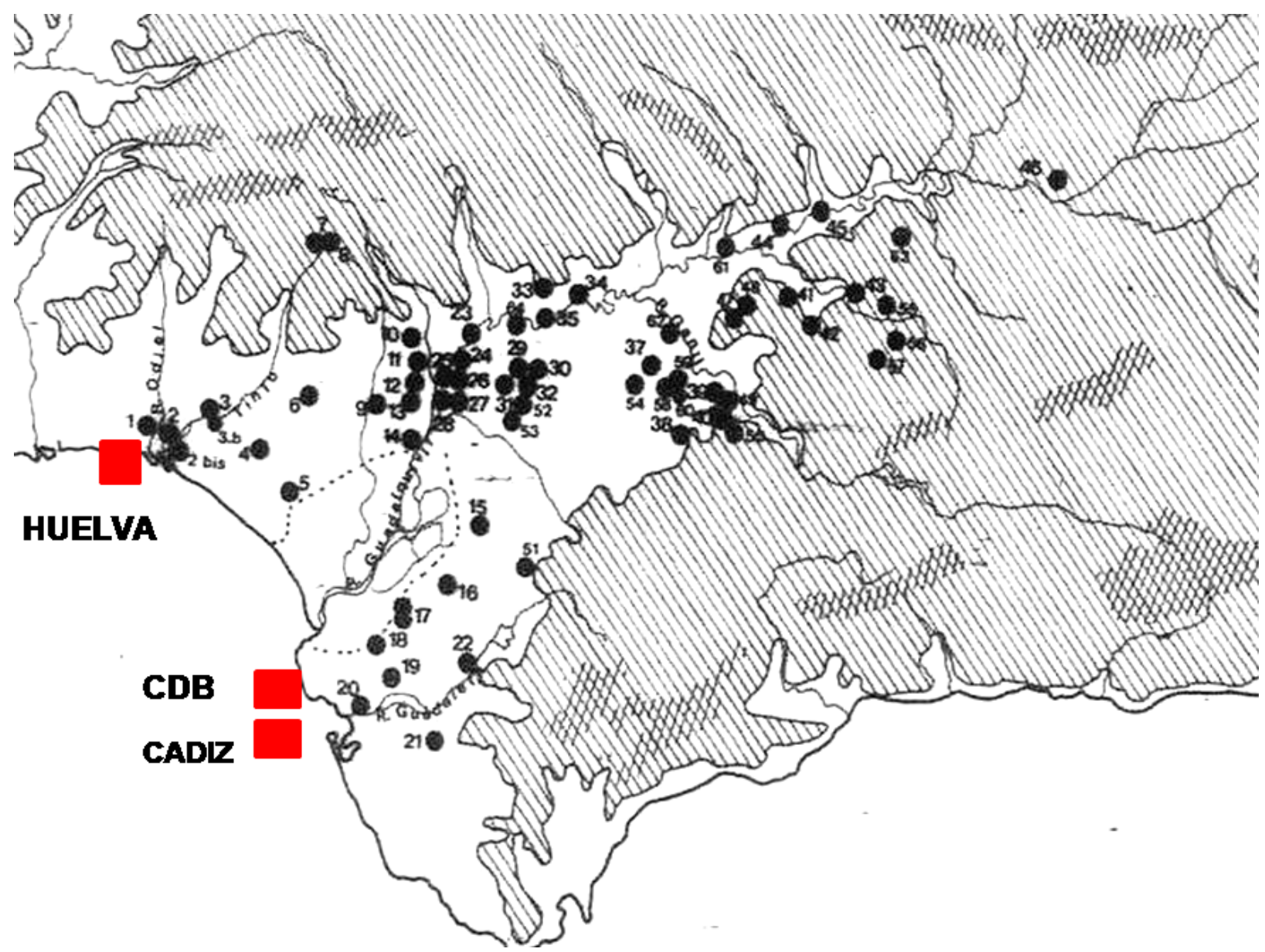

Figura 4. Los principales asentamientos indígenas en el Bajo Guadalquivir y Huelva a la llegada de los fenicios. Sólo se señalan en puntos negros unos cuantas asentamientos (Diego Ruiz Mata)

ellas se obtiene, después de muchos años de elucubraciones, una imagen más real topográfica de la isla, de la secuencia de los primeros siglos, del posible tamaño de la ciudad y de un cálculo aproximado de habitantes, características de sus viviendas, el elenco de cerámicas conducentes a sus prototipos de Tiro y a la fecha fundacional, alejada, como cabía esperar de V. Patérculo. A lo que se unen los trabajos de la PSA y los del Cine Andalucía (CAn). Sólo me detengo con brevedad en los lugares excavados en este siglo, que han proporcionado un vuelco sustantivo al tema esperado de sus inicios fenicios, sin discusiones de detalles, que haré en otra ocasión.

El TC, en su amplio espacio excavado, suficiente para fijar parte del núcleo urbano, ha proporcionado una secuencia desde finales del siglo IX a.C. a época romana y una información topográfica quizás distinta de la imaginada. En este sentido, el TC se asentaba sobre una pequeña elevación de poco más de 6 $m$ de altura, y bajaba en una pendiente suave hasta el Canal Bahía-Caleta, casi al nivel del agua, distante menos de $100 \mathrm{~m}$ de este núcleo (Gener et al., 2014). Se distinguieron con claridad cuatro fases de época fenicia, desde el 820/800 hasta el segundo y tercer cuarto del siglo VI a.C. La más significativa es la fase II, datada entre el 820/800 a.C. y 760-750 a.C., que posee ya estructuras urbanas y ha ofrecido un considerable conjunto de cerámicas. Es ahora cuando se puede hablar objetivamente de un núcleo fenicio, de un establecimiento urbano y de estratos delimitados y datados. Las hipótesis y contextos forzados, que reunían como en un puzzle datos diversos y de distintos sitios, han dado paso a elementos arqueológicos seguros, que son los válidos para la contrastación entre las fuentes escritas y la arqueología y a la creación de una estructura histórica fundamentada. Lo que constituye uno de los logros más importantes de toda su historia arqueológica en la isla, siempre movida por la incertidumbre de los contextos y las suposiciones sin fundamentos (Figuras 5-7). 


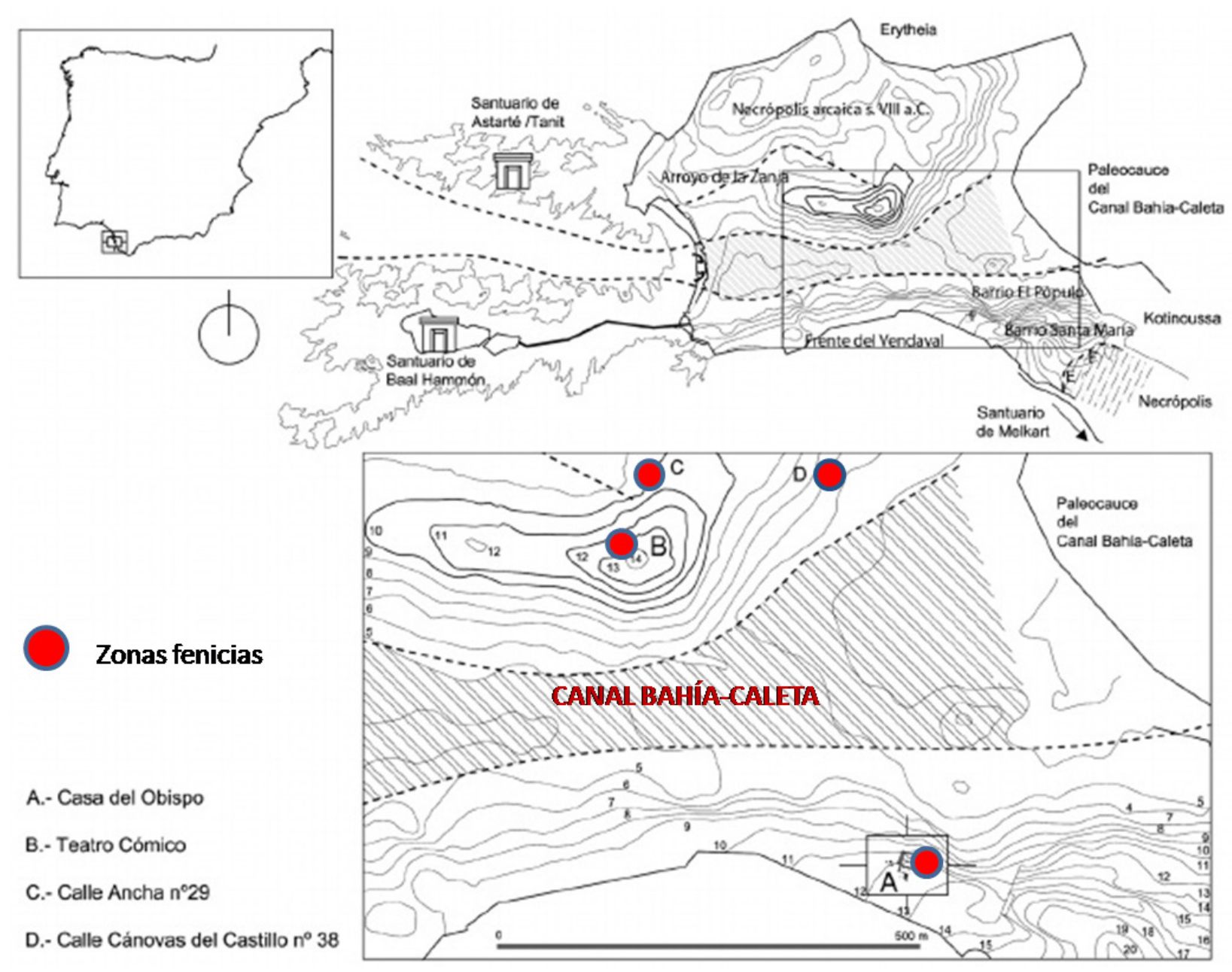

Figura 5. La isla Eritia gaditana en la época de su fundación fenicia. Se indican el canal Bahía-Caleta y las excavaciones que han proporcionado niveles fenicios arcaicos (Según J.M. Gener Basallote).

En las cercanías al TC, se excavó una zona amplia en CdC- (Córdoba y Ruiz Mata, 2005), y en un solar de CA (Ruiz et al., 2014), que más adelante emplearé para la delimitación de lo que debió ser el núcleo estricto urbano y los alrededores no urbanizados. CDC es un espacio de casi $400 \mathrm{~m}$ cuadrados, en el que se alcanzó el suelo natural, a -2.70 $\mathrm{m}$ de profundidad del nivel de la calle actual. Aquí sólo se ha hallado el suelo natural y una zona de trabajo relacionado con alguna actividad pesquera, que se compone de renovaciones de varios pisos de arcilla. Se ocupó en los primeros decenios del siglo VIII a.C. El conjunto cerámico fue numeroso, explícito y suficiente para su datación. Es un núcleo contemporáneo de la fase II del TC. Y más cerca, en CA, próximo al lugar donde se halló el Sacerdote de Cádiz o dios Ptah, se excavó un pozo ritual, que no alcanzaba el nivel freático, y al que se sobreponía, cubriendo su embocadura, un conjunto de niveles con vestigios de celebraciones de banquetes rituales. Suponemos que pozo simbólico y rituales de banquetes pueden relacionarse con una hipotética tumba en la que se halló la figurilla de Ptah, a pocos metros de aquí. Los materiales se datan en la fase II del TC. Esta zona quedaba también extrarradio del propio ámbito urbano del TC. A ambos lugares se les han considerado espacios periurbanos de la ciudad. Y así es. Son zonas cercanas de la ciudad, exentas de viviendas, que no se integran en su núcleo urbanizado. Su interés, al margen del que arqueológicamente tienen per se, es el de que delimita la extensión de la ciudad fenicia arcaica. Cuestión importante.

Otro punto, excavado en esos años, es la CO, en el Barrio del Pópulo al otro lado del canal, y en la isla mayor Cotinusa (Gener et al., 2014). Aquí se 
hallaron niveles fenicios, hiatus y niveles romanos, como sucede en el TC. En este caso, son dos las fases de ocupación fenicias. La más antigua muestran vestigios de casas con muros de arcilla, de menor calidad que los del TC, y materiales datados desde el siglo VIII a.C., sin especificar, hasta principios del VI a.C. La fase II, peor conservada por las estructuras romanas posteriores, parece que siguió el sistema constructivo previo. Se data desde un momento impreciso del siglo VII hasta una época avanzada del VI a.C. Es curioso que en este punto el siglo VI a.C. marque, como en el TC, el final de la actividad en ese sitio y el inicio de un amplio hiatus hasta época romana. Es muy posible que esta situación de abandono se relacione con la caída de Tiro, que debió causar unos momentos de inestabilidad política y de cese de relaciones.

Cádiz tiene, por fin, en estas zonas investigadas, argumentos arqueológicos seguros de los primeros momentos de la fundación de la ciudad y de su fecha. $\mathrm{Y}$ en lo que se refiere a su carácter sacro, se poseen manifestaciones en el entorno de la CO, en el que se erigió un monumento funerario a me- diados o segunda mitad del siglo VI a.C. (Gener et $a l ., 2014)$ y posiblemente en la CA en el siglo VIII a.C. en torno al Ptah o personaje allí enterrado. Los templos de Astarté y de Cronos (Maya et al., 2014), situados en los lugares que se indican, constituyen la representación de la esencia sagrada de la ciudad y de su sentido espacial religioso. Insisto en este aspecto por la importancia que tuvieron sus templos, situados, como el de Melqart, en una isla, y la importancia de la ideología religiosa en el proceso de la colonización y en su perduración, como referentes étnicos y culturales. Y la captación ideológica del espacio mediante la ideología religiosa y su implantación. Conquista ideológica.

Mas los problemas de la fundación de Gadir no están aún solucionados, ni limitado a la propia isla gaditana. Aunque las fuentes son claras en cuanto a la fundación de la ciudad y del templo de Melqart, quedan interrogantes que hay que contestar. El templo de Melqart en Sancti Petri no está sólo relacionado con la isla gaditana y su ciudad. Debe tener un sentido y función más amplio en un territorio más extenso. Y los trabajos recientes en el

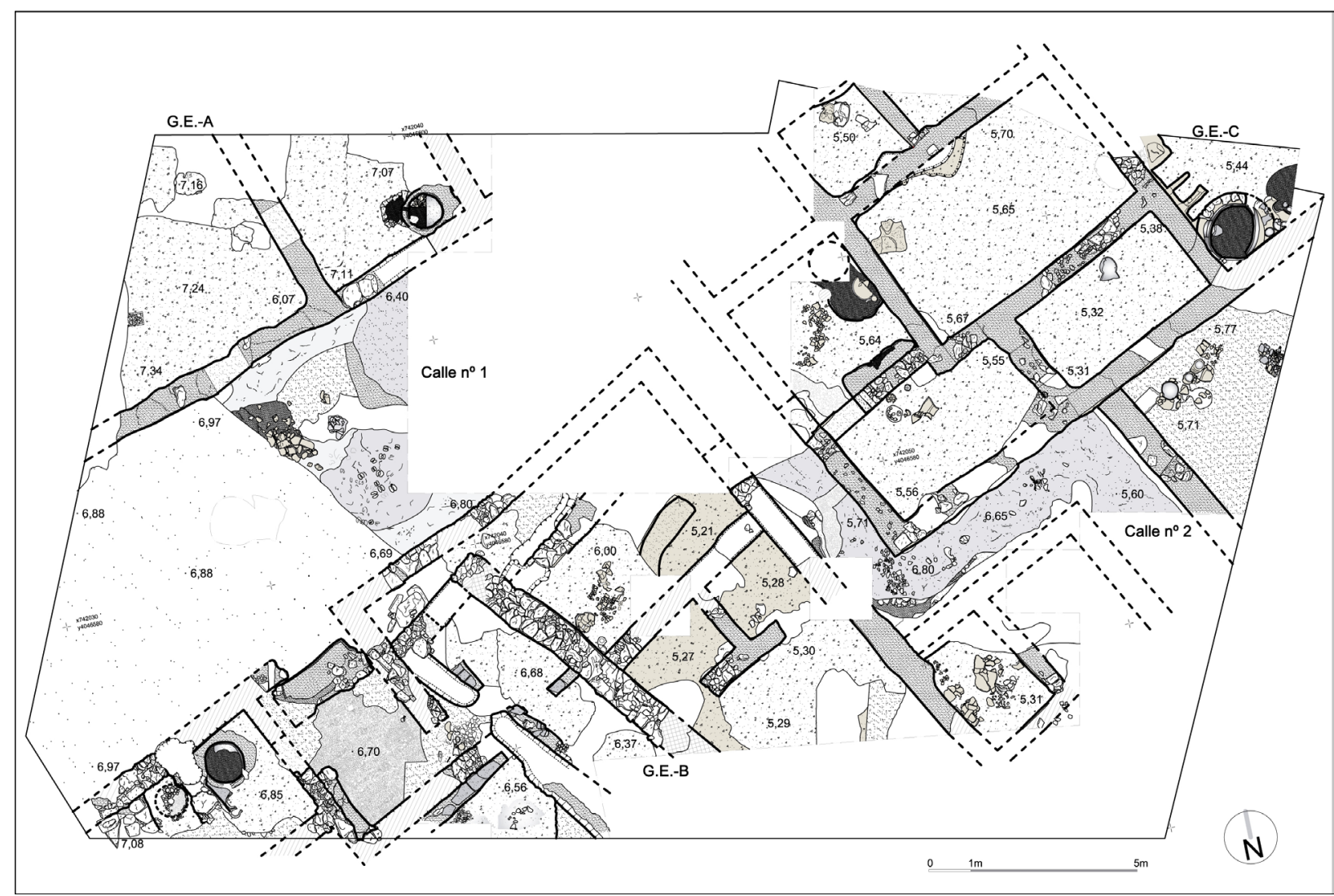

Figura 6. Planta de la viviendas del TC de la fase II (Según. J.M. Gener Basallote) 


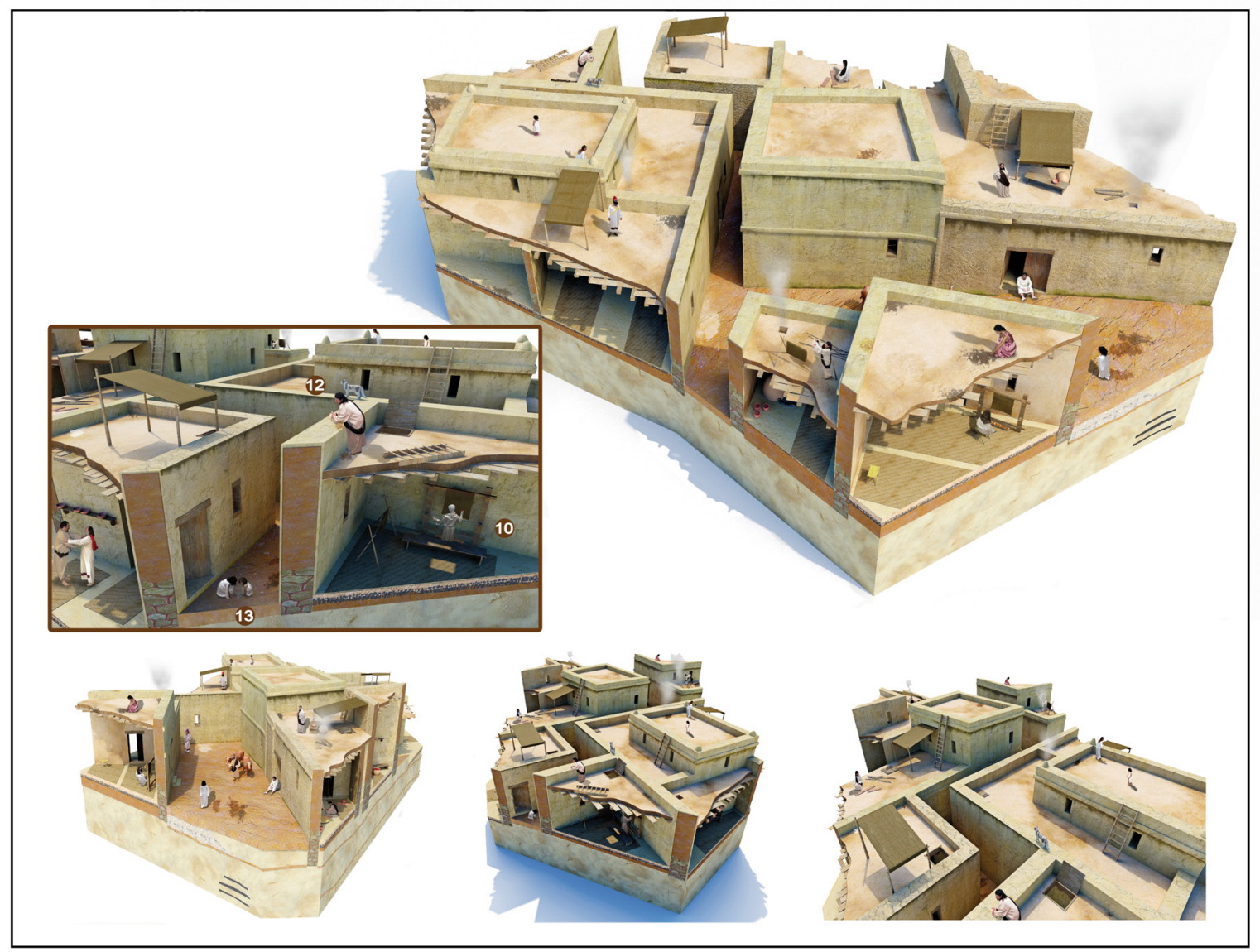

Figura 7. Reconstrucción de la planta de la figura 6 (Según J.M. Gener Basallote)

CdCa, en Chiclana (Bueno, 2014), donde se excavó un recinto fortificado de casamatas (Bueno, García y Prados, 2013) y materiales fenicios aún datados con imprecisión, abren la pregunta de su relación con el templo de Melqart. Y si la hubo, cuál fue su naturaleza y función. Parece que San Fernando no se ocupó durante estos primeros momentos. Pero el $\mathrm{CDB}$, y su conjunto, es el protagonista silente, y tuvo un protagonismo excepcional desde su fundación.

\section{8-13).}

El CDB, en silencio, ya lo anunciaba (Figuras

Ignoro las razones por las que lugar tan importante, tan a la vista en la Bahía y del navegante, con su amplitud urbana amurallada y su entorno arqueológico de casi $400 \mathrm{Ha}$, incluyendo puerto, zona portuaria, "zona periurbana", necrópolis y SSC, punto privilegiado de referencia y de vigilancia, además de su ocupación con una zona industrial del siglo III a.C., haya quedado arrinconada en la historia y no haya promovido la curiosidad de geógrafos griegos y romanos, ni siquiera en la relación indudable con la Cádiz fenicia y púnica. Ignoro, de verdad, su muerte en vida, en las referencias textuales, que tuvo desde su fundación. Lo entiendo desde su trágico final de guerra con la presencia de Roma en la isla de Cádiz y su ejército, cuando, fiel a Cartago, fue asediada, en parte incendiada y abandonada del todo. ¿Sufrió damnatio memoriae por su fidelidad en la guerra a Cartago, mientras Cádiz, fiel a Roma, prosperaba? Tenemos, pues, un CDB cartaginés y una Cádiz romana. Es lo que los datos denotan. Y así me explico el silencio de las fuentes. Estaba a la vista de todos en un lugar transitado, sus murallas del siglo III a.C. se alzaban aún a gran altura, como lo hicieron hasta el siglo XVIII y XIX según los viajeros curiosos (Ruiz Mata, 1995). Y supongo que la mayoría de sus restos urbanos. ¿Cómo se explica, cómo es posible su silencio cuando los restos emergentes hablaban de su historia? Desde Cádiz, la Sierra se destaca como el punto más alto de la Bahía 


\section{La Sierra de S. Cristóbal y los yacimientos arqueológicos protohistóricos investigados en el proyecto sistemático (400 Ha de extensión)}

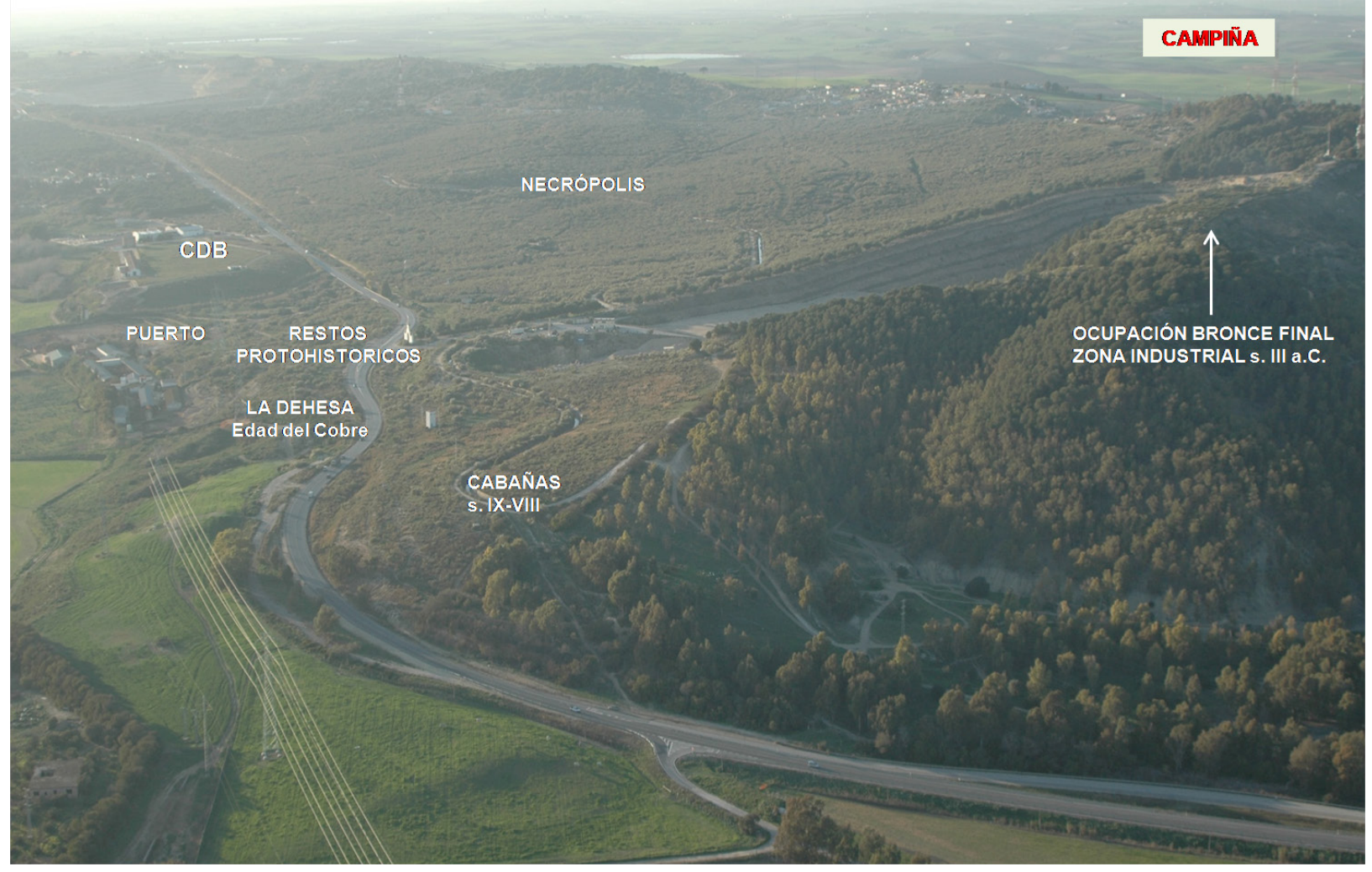

Figura 8. La Sierra de San Cristóbal (El Puerto de Santa María, Cádiz) y las zonas arqueológicas protohistóricas (Diego Ruiz Mata) sobre foto aérea.

gaditana y los muros de la ciudad se debieron manifestar imponentes. ¿No pasó por Cádiz ningún geógrafo investigador, erudito e historiador curioso que se preguntase cuál fue el nombre de esa ciudad, cuál fue su historia y la transmitiese? Cuando algo se ve tan manifiesto a la vista, tan cerca de Cádiz o navegando, y se oculta, la razón no puede ser otra que política y estratégica, de olvido intencionado. Lo supongo, pero no dispongo de textos que lo confirmen. Sabemos que los informes fenicios y púnicos, que debió haberlos, se hallan perdidos, e ignoramos lo que se escribió de ella y cuál fue nombre fenicio, aunque sólo fuesen asuntos de negocios o simples anécdotas de marinos y comerciantes. Pero iy los más tardíos grecorromanos con objetivos más científicos? A veces el silencio es una respuesta explícita en el conjunto de los datos tangibles. Un modo de borrar el pasado de algo que molesta.
Las excavaciones y prospecciones en el entorno del CDB manifiestan la existencia de una ciudad de extraordinaria importancia fundada al mismo tiempo que la de la isla gaditana. La elección de la isla, sin demasiada agua ni territorio productivo, se explica por la implantación de un modelo ya visto en la propia ciudad de Tiro -isla y costa (Carayon et al., 2011)-, en Arwad y Tartus (Siria) e incluso en Rachgoun (Laporte, 2004; Carayon, 2011; Bartoloni, 2012) y Mogador (López, 1996; López y Mederos, 2008). Sus carencias de elementos esenciales justificaban la fundación de la ciudad del CDB, situada en el punto más privilegiado de la Bahía. Porque, creo, que Cádiz también fue elegida no sólo por ser una isla, sino por ser un punto estratégico y simbólico, político y religioso, en un entorno geográfico de grandes posibilidades productivas y comerciales, que se hallaba enfrente a pocas millas marinas, $y$ a pocas horas de navegación, y cerca del estuario 


\section{EL ESPACIO ARQUEOLÓGICO DE LA CIUDAD FENICIA DEL CASTILLO DE DOÑA BLANCA (EN TORNO A $300 \mathrm{Ha}$ )}

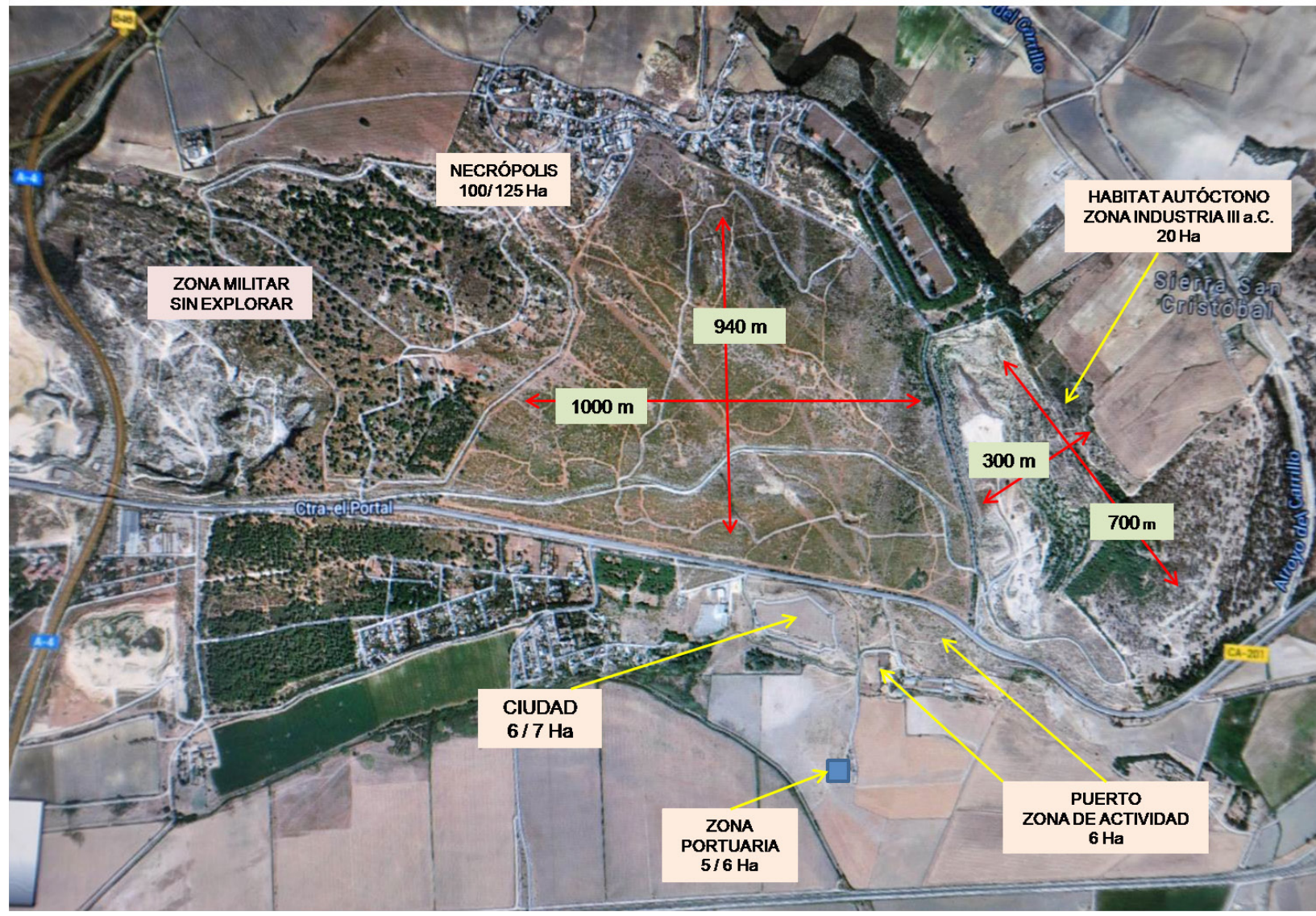

Figura 9. Las zonas arqueológicas de la Sierra de san Cristóbal (El Puerto de Santa maría, Cádiz) sobre una foto aérea de Goggle Earth, modificada por Diego Ruiz Mata. Se indican distancias y dimensiones.

del Guadalquivir, navegable y habitado densamente (Figura 4). Sin estas circunstancias, no se explica la fundación de Gadir. Huelva, por ejemplo, adquiere sentido como catalizador del comercio de plata de más al interior, de Riotinto. Y en el caso de Cádiz, no por la bondad de una isla sin elementos, sino por la existencia de la costa, la campiña, el Bajo Guadalquivir, sus posibilidades agropecuarias y su población autóctona.

En este panorama es preciso preguntarnos qué factores favorecieron la fundación del CDB. Entre los más relevantes y esenciales se pueden destacar los siguientes:

1) su situación geográfica al pié de la SSC, que la protegía de los molestos vientos de Levante, y junto a la antigua desembocadura del río Guadalete, que proporcionaba agua y la posibilidad de navegarlo hasta algún punto del interior.
2) la sierra que protegía a la ciudad y le proporcionaba un punto de visión a largo alcance hacia el mar y hacia el interior, como protección, pues desde la propia ciudad la visión sólo alcanzaba el espacio reducido marino hasta la isla de Cádiz, y al puerto que debió estar situado muy cerca de la ciudad en su flanco oriental.

3) la sierra constituía un punto de referencia para el navegante, esencial en el mar en el que las señales peculiares topográficas costeras constituyen jalones orientativos necesarios para el marino, en su navegación costera y con la vista siempre orientada hacia la costa.

4) la calcarenita para la construcción, una materia prima fácilmente extraíble, cuyo uso se advierte durante toda la vida de la ciudad.

5) la abundancia de agua dulce, que corría a pocos metros bajo la superficie donde se fundó la 


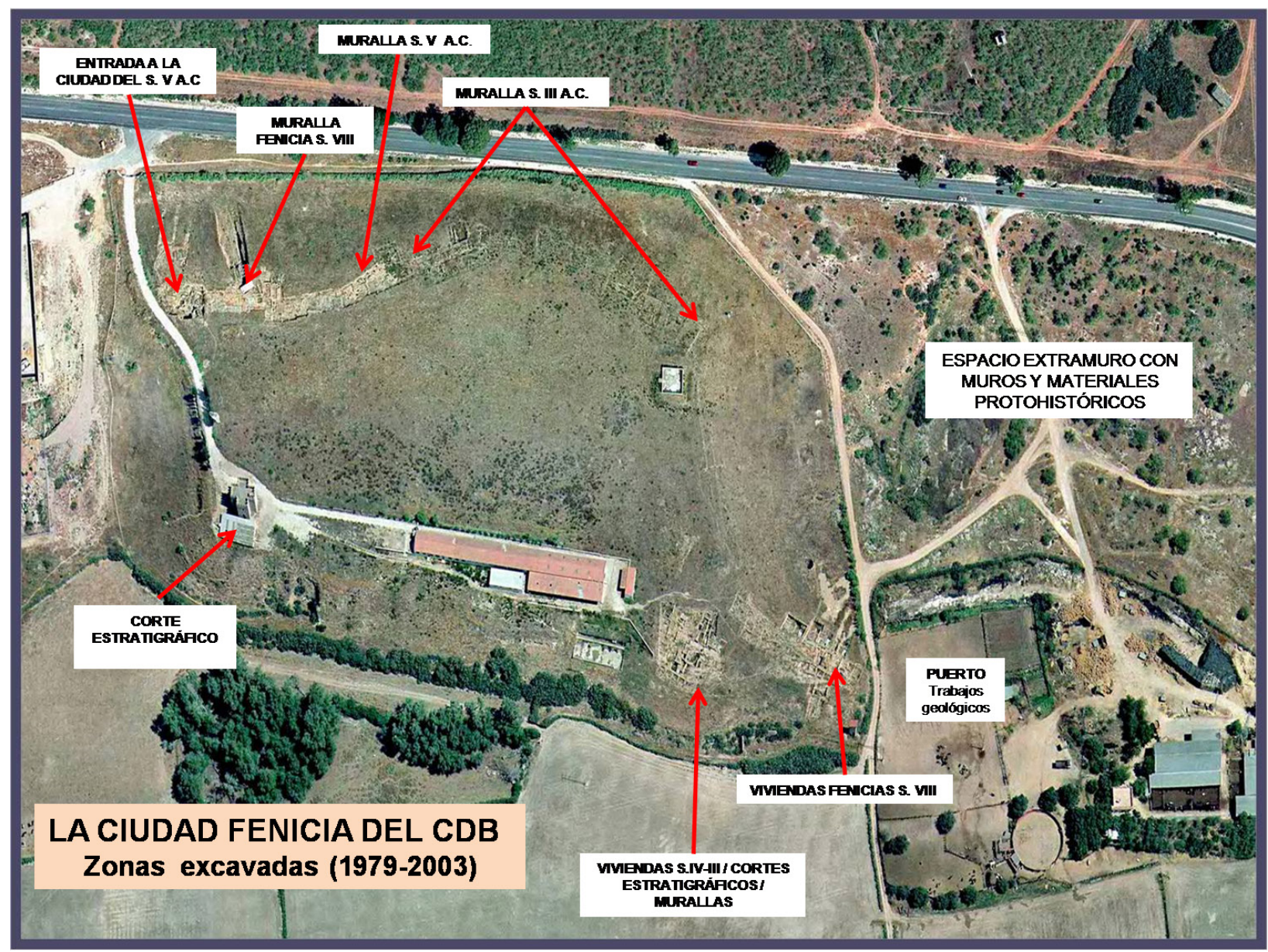

Figura 10. Foto aérea de la ciudad fenicia del CDB con indicación de las zonas excavadas (Diego Ruiz Mata)

ciudad, y manifiesta un pozo en el interior de una torre de entrada a la ciudad del siglos V-IV a.C..

6) la abundancia de madera, consistente en una masa forestal de pino, olivo silvestre, quejigo y encina, sabidos por los estudios antracológicos (Roselló y Morales, 1994), efectuados en los diferentes estratos y épocas de la ciudad, que favorecían la construcción de viviendas y posiblemente de embarcaciones o sus reparaciones.

7) la cercanía al estuario del Guadalquivir, navegable hasta aguas arriba de Sevilla, y de los esteros donde se establecieron ciudades protohistóricas y romanas.

8) la proximidad a las salinas y a los ricos bancos de pesca, advertidos en los análisis ictiológicos (Roselló y Morales, 1994.

9) la extensa y fértil campiña tras la SSC, como alaba Estrabón, al que me refiero como la voz de otros muchos, y manifiestan las villas de campo y el considerable número de ánforas de todos los tiempos, que sólo pueden ser testigos explícitos de la producción de productos.

10) y por último, como factor de similar e incluso de más importancia, la existencia de una población indígena en la sierra y en todo el amplio entorno de la campiña, hasta el estuario del Guadalquivir, requerida como mano de obra -no hay colonización efectiva sin autóctonos-, por su conocimiento preciso del terreno, de captación de recursos y para el intercambio inicial del comercio, como muestran las viviendas de muchos poblados indígenas; y para el sostenimiento y crecimiento de la población.

En el terreno estricto arqueológico, la ciudad desde el comienzo ocupó el espacio que actualmente se advierte en el perímetro de la colina artificial, en torno a $6.5 \mathrm{H}$., y se protegió con una potente muralla, provista de bastiones y de un foso defensivo al menos en su flanco norte. Lo que tuvo lugar en los inicios del siglo VIII a.C. En los siglos V-IV a.C. y III a.C. se construyeron sendas fortificaciones de 
casamatas, y a fines de este siglo, y como obra de los bárcidas, se reforzó en varios puntos con las técnicas de Cartago. En su entrada sudeste se hallaba seguramente el puerto, como sugieren las perforaciones que se efectuaron para conocer el proceso de su relleno. Y algo más lejos, unos $250 \mathrm{~m}$ al sur de la ciudad, se ha detectado una posible zona portuaria, que he mencionado en otras ocasiones y de la que se desconoce su momento de construcción. Y como dato relevante, por el interés y persistencia de ocupación de ese sitio y su significado económico, hay que destacar su potente estratigrafía de casi $9 \mathrm{~m}$ de potencia -desde el 800 a.C. hasta fines del siglo III sin interrupción-, el número considerable de renovaciones de su urbanismo y las tres murallas construidas ex novo. Lo que se traduce sin dudas en riqueza y capacidad de recursos. Tal actividad constructiva conduce a esta reflexión, si se consideran la mano de obra empleada y los costes de las nuevas construcciones, que aprovechan muy poco de lo anterior, salvo los cimientos en alguna ocasión. Sin recursos no hay ciudad que se renueve en tantas ocasiones ni se construyan tres fortificaciones en esos quinientos años, por mucho que las deteriore el tiempo.

La necrópolis se halla cerca de la ciudad, al norte, y ocupa una extensión de unas $125 \mathrm{Ha}$. Aún no se ha prospectado con detenimiento, debido a la negativa de los propietarios en estos últimos años. Por lo que conocemos hay que imaginarla como un lugar sagrado, una necrópolis con arbolado y agua que fluía por los arroyos que rasgan su superficie, donde se disponían los enterramientos en lugares precisos y en un orden simbólico y categórico. Y en el siglo III a.C., la ciudad se extendió hacia la zona alta de la sierra, ocupando con probabilidad 5 ó $6 \mathrm{Ha}$. Al este de la ciudad amuralla se han hallado restos de época arcaica y muros del siglo III a.C. Lo que denota una actividad extramural que hay que calibrar y determinar en futuros trabajos de campo. Todo puerto tiene un espacio aledaño relacionado.

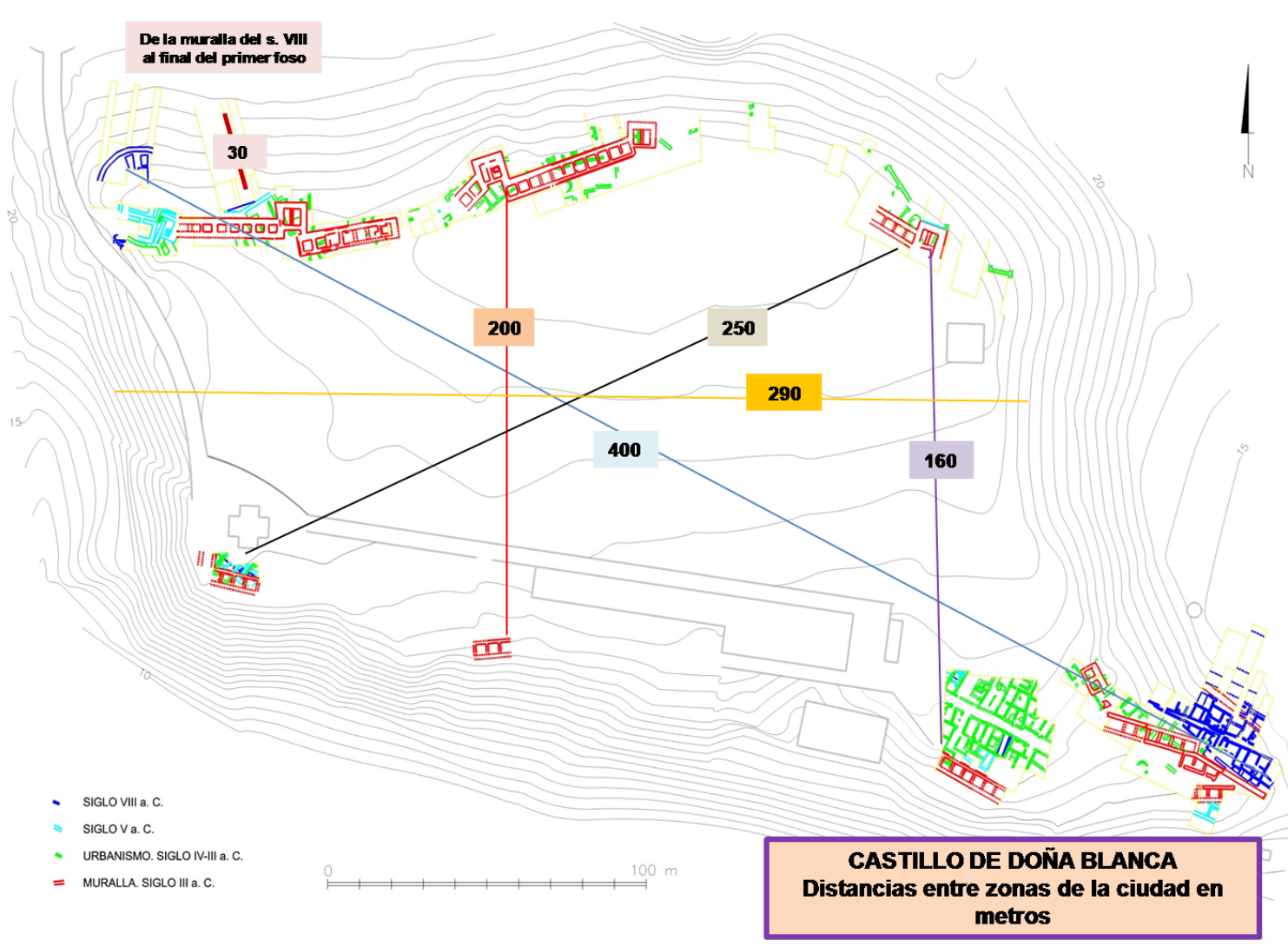

Figura 11. Planimetria del CDB con indicación de las distancias (Según Diego Ruiz Mata) 
Su potente estratigrafía muestra una secuencia continúa desde su fundación hasta su abandono. Con anterioridad, la SSC se ocupó durante la Edad del Cobre (Ruiz Mata y Pérez 1995). En su zona baja, en La Dehesa, se han excavado un conjunto de cabañas pertenecientes al poblado, que debió extenderse por debajo del suelo prefenicio del CDB. $Y$ desde esta época, la sierra debió ser un importante centro religioso, como sugieren un altar de cazoletas situado en su punto más alto y una estelamenhir de gran tamaño, como centro sacro y ritual, con grabados simbólicos que conectan con el oeste francés. El Bronce Pleno no ha ofrecido aún el lugar de su habitación, pero en la necrópolis se ha excavado el Hipogeo $\mathrm{n}^{\mathrm{o}}$ 1, con casi una treintena de inhumaciones, y detectado dos más. Y cabañas del Bronce Final se dispusieron en la planicie más alta de la sierra. Debió ser la población prefenicia que en poco tiempo convivió en el interior amurallado de la ciudad fenicia, en un proceso rápido de integración y adaptación en todos los aspectos de la ciudad y en la producción, comercio y navegación (Ruiz Mata y Pérez, 1995).

De la historia de ocupación del tell indicaré sólo varios aspectos: 1) su fundación tuvo lugar hacia el 800 a.C., al mismo tiempo que el TC en Cádiz; 2) en su fase inicial -siglo VIII a.C.- se delimita la ciudad, se construyen las primeras viviendas en las que se advierten rasgos y técnicas constructivas orientales -muro de pilares, por ejemplo-, y se construye la muralla; el material fenicio se emparenta con el de Tiro y con el de otras áreas fenicias cercanas a la metrópolis, entremezclado con materiales indígenas, como cabía esperar en una ciudad que los albergaba, para sus firmes propósitos productivos y comerciales; y un rasgo de su importancia es su carácter de puerto internacional, con ánforas procedentes de la costa levantina mediterránea, de

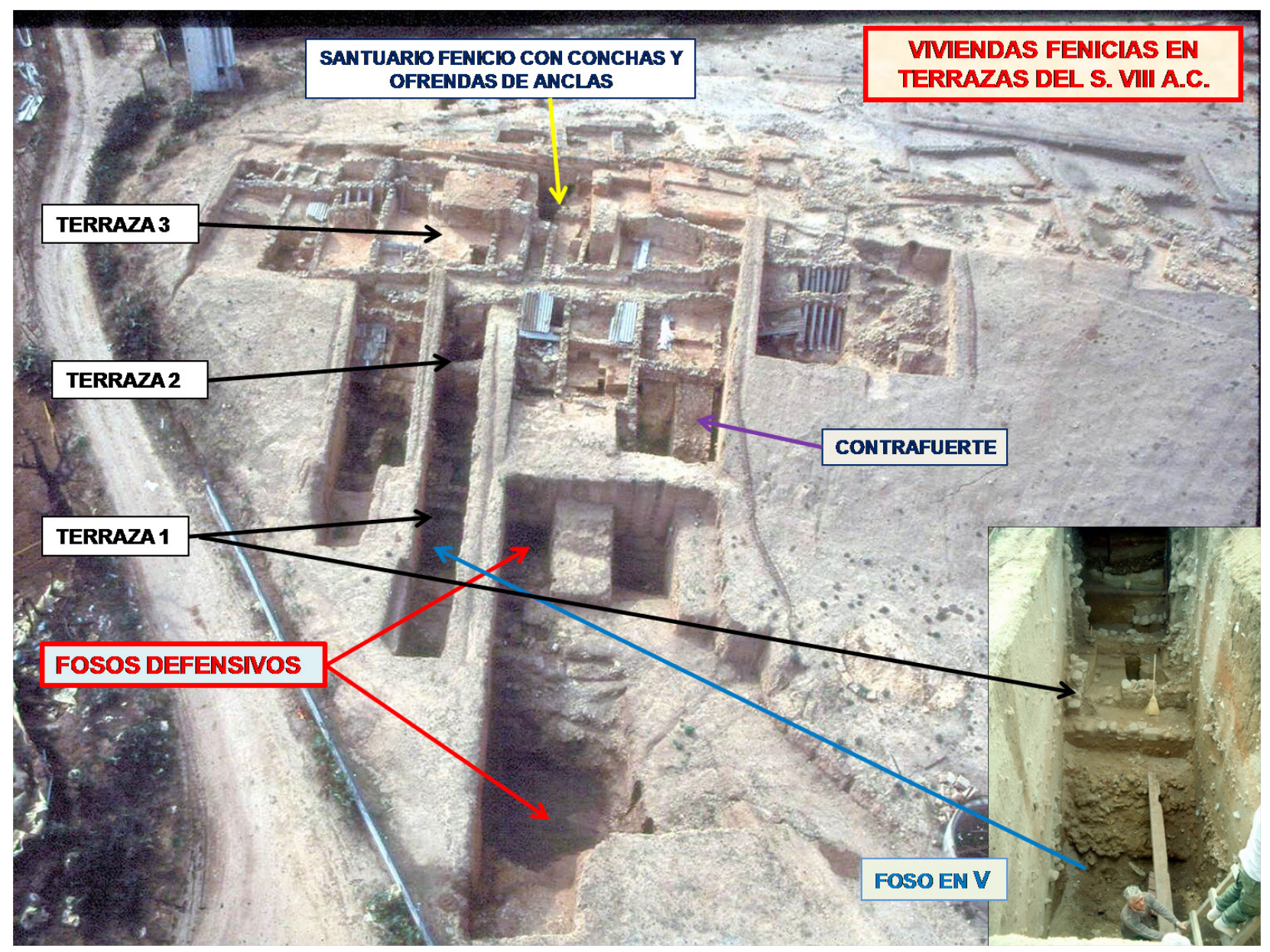

Figura 12. Viviendas fenicias del CDB en terrazas, del siglo VIII a.C. (Fotos de Diego Ruiz Mata) 


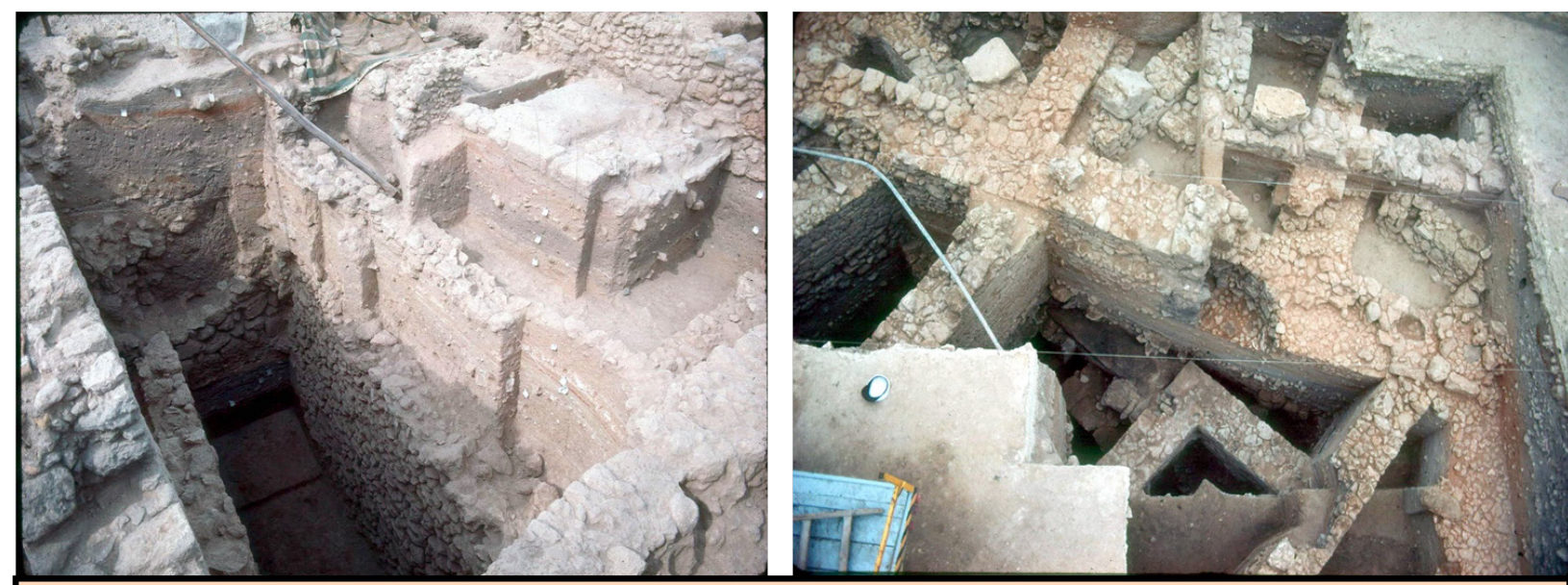

\section{ESTRATIGRAFIAS QUE MUESTRAN LA INTENSA ACTIVIDAD URBANA DE LA CIUDAD, RESULTADO DE SU PROSPERIDAD ECONÓMICA Y ORGANIZACIÓN POLÍTICA DESDE SUS COMIENZOS}

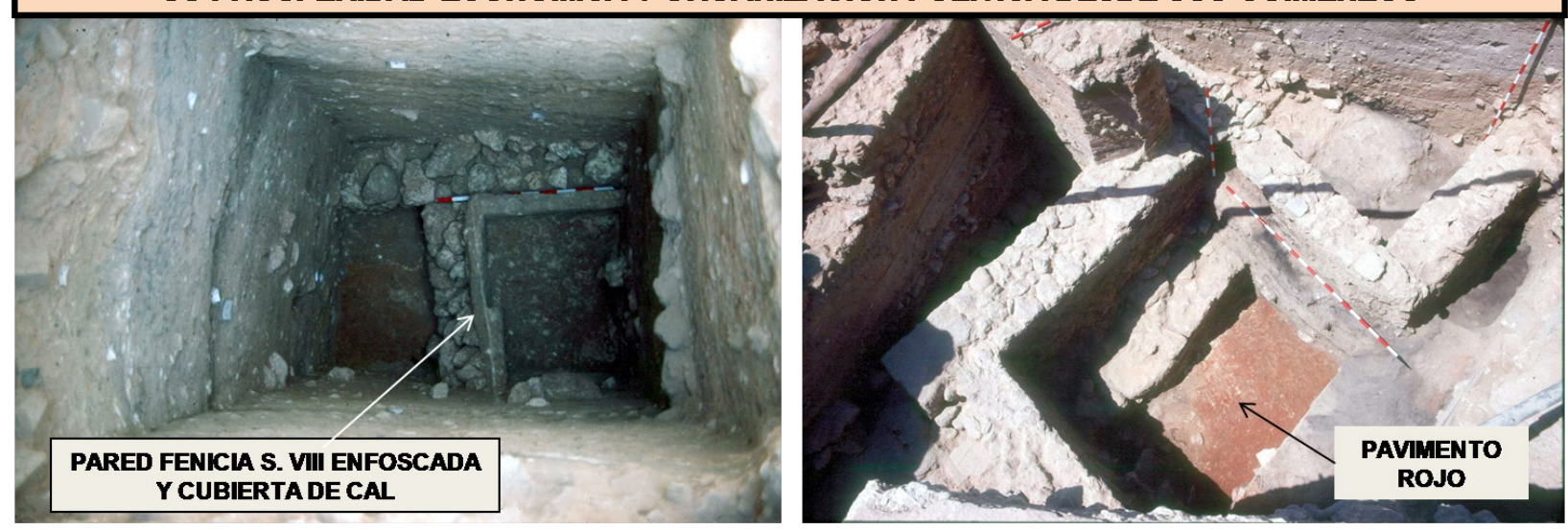

Figura 13. Estratigrafías del CDB (Fotos de Diego Ruiz Mata)

Cerdeña , Cartago y de otros puntos que no se han determinado aún; 3) desde fines del siglo VIII a-C. y durante todo el siglo VII a.C se percibe una fase de integración y consolidación, con materiales que están presentes ya en la mayoría de los poblados conocidos; es el momento del abandono de poblados autóctonos de sus alrededores, que se fueron integrando en la ciudad, el momento de mayor intensidad en la expansión hacia el interior peninsular y el Atlántico, el de la restricción del comercio exterior mediterráneo e intensificación del interior occidental, manifiesto por los tipos de las ánforas, y el de la plenitud del Período Orientalizante; 4) durante el siglo VI a.C. se observa una cierta decadencia que hay que comprobar, por falta de excavaciones en extensión de esta época, el inicio de un cambio en los tipos cerámicos, quizás relacionado con Cartago y su presencia efectiva occidental, y el comercio con la Grecia Oriental; 5) desde finales del siglo VI
a.C. y durante el siglo $\mathrm{V}$ a.C., comienza el período turdetano-púnico, que supone un notable desarrollo urbano, la aparición de las cerámicas características de esta fase y un comercio exterior, básicamente con ciudades griegas del mediterráneo central y del área de Cartago; 6) en el siglo IV a.C. se fortifica de nuevo la ciudad y se intensifica el comercio con Grecia; 7) durante el siglo III a.C. la ciudad renueva por tercera vez su muralla, con el sistema de planta zigzagueante y casamatas cuadradas y amplias y tramos entre torres, se construye gran parte de la ciudad; se instala en la cima de la sierra una zona industrial, y las cerámicas griegas dan paso a las rojas de Kuass, que son las formas griegas adaptadas al gusto de Cartago -su expresión helenística-, y su extensión delimita el espacio político, comercial y estratégico en los preludios prebélicos y de preparativos de la Segunda Guerra Púnica; 8) entre 215 y 210 a.C., como atestiguan un conjunto de monedas 
halladas en el interior de una estructura bárcida, la ciudad se ofrece signos de violencia, se incendia parcialmente y se abandona, constituyendo su final. De época romana no hay nada notable en su superficie, salvo cerámicas aisladas. Delante de la muralla, en el sur, se hallaron vestigios de viviendas romanas de los siglos III-IV d.C., y de estos siglos se excavaron tumbas en la zona sur de la necrópolis.

Y VAYAMOS AL TIEMPO, ESE GRAN DESTRUCTOR DE MITOS.

Si la fecha de 1100 a.C. para la fundaciones de Gadir, Utica y Lixus, transmitida por las fuentes y grabada en algunas mentes todavía, se va diluyendo ante la escasa o nula posibilidad de verificarla, la tendencia aún permanece hacia la datación de los materiales en esa fecha discutida. No se esgrimen argumentos de defensa de 1100, pero sí del 1000 o 900 , de 850 o de 800 a.C. Es decir, aún no hay un acuerdo sobre la fechas de estas fundaciones más antiguas fenicias, teniendo a la vista $u$ material arqueológico muy expresivo. La de Cartago, en el 814 a.C., parece coherente con los datos existentes de los niveles profundos de la ciudad. Las fechas absolutas de $\mathrm{C}^{14}$ tampoco concuerdan con las convencionales ni entre ellas mismas, pues un espacio de tiempo 20 o 40 años es mucho, en el que han podido suceder numerosos e importantes acontecimientos, por la rapidez del ritmo histórico que se advierte en la protohistoria. Lo que es natural a medida que las diversas tecnologías, población y el poblamiento crecen y se extienden y aceleran el tiempo histórico, que siempre es relativo.

Durante mucho tiempo, incluso ahora, los medios empleados para la datación del material fenicio, en su acepción relativa, forman un entramado de conexiones, de analogías formales y decorativas, originados en los prototipos orientales. El lugar de referencia debe ser Tiro, pues de ahí surge la iniciativa colonial. Pero no ha sido hasta 1978 cuando se publicaron los resultados de una estratigrafía (Bikai, 1978) que aún es el referente de contrastación obligada para los materiales occidentales, en sus primeros momentos. Los datos procedentes de Sarepta (Anderson, 1981) y Tell Abu Hawan (Herrera, 1989) y Chipre -horizonte de Kition- (Bikai, 1987) también se consideraron en las comparaciones tipológicas. Y otras más.

En este sentido, las dataciones convencionales o relativas, basadas en las cerámicas de Tiro, sitúan la totalidad de los asentamientos occidentales más an- tiguos, salvo Huelva -Plaza de las Monjas/Méndez Núñez-, en los estratos III y II ese yacimiento, y en algún caso en el estrato IV, es decir, en la mitad del siglo VIII a.C. o muy poco antes, en sus comienzos.

Las relaciones tipológicas con estas ciudades, con Chipre en el "horizonte de Kition" (Bikai, 1987), y con otros asentamientos levantinos han sido el instrumento más empleado de datación. Mas las cronologías del $\mathrm{C}^{14}$, y su confrontación con las convencionales, conducen, por lo general, a dataciones más altas. Pero aún queda trabajo por hacer y análisis que efectuar, contrastar y mejorar las muestras. De ello ya me ocupé en extensión en otro trabajo (Ruiz Mata et al., 2014). Sólo incidiré en los aspectos que creo más conveniente para situar en el tiempo las fundaciones de Cádiz y CDB, tras los primeros contactos con Huelva y Málaga.

Es importante determinar la fecha de la fundación de Cartago, por sus analogías cerámicas con las del Mediterráneo Central y las occidentales en sus inicios. Sus estratos más antiguos son exiguos y de extensión insuficiente para determinar su carácter. Lo que se debe a la dificultad que el arqueólogo encuentra para alcanzar los más profundos en la maraña de muros superpuestos de épocas fenicias más tardías y romanas. Según Timeo (ca. 350-260 a.C.), fija su fundación en 814-813 a.C., 38 años antes de la Primera Olimpiada, contemporánea de Roma. El problema es, como observa Christensen (2007), que la datación de esta Primera Olimpiada es dudosa, porque no resulta claro el sistema empleado para determinar su año de comienzo. La cronología convencional de la colina de Byrsa para su estrato más antiguo es la de 760 a.C., según el material griego del Geométrico Tardío que lo acompañaba y sus concomitancias con Tiro III-II, o poco antes, estratos V-IV (Docter at al., 2008). Mas los resultados de seis nuestras, recogidas en estratos problemáticos, fluctúan entre el 830 y 730 a.C. o entre el 830 y 805 a.C. (Van De Plicht et al., 2009). Estamos ante la aplicación de una datación alta. Sin embargo, estas muestras analizadas en la universidad de Ghent son más recientes, hacia el 800 a.C. como fecha límite más alta. Fantalkin advierte que, debido a la naturaleza del depósito, las fechas de $\mathrm{C}^{14}$ en este caso son de escaso valor para determinar la fundación Cartago y para la fijación de la Edad del Hierro (Fantalkin et al., 2011). Esta fecha para la fundación de Cartago es sustancial por las relaciones que posee con el material más antiguo de Cádiz y CDB, que marcan la presencia y fundaciones fenicias en 
la Bahía y en el Bajo Guadalquivir. En conclusión, fuentes y dataciones relativas y absolutas no son muy disonantes. Y quizás habría que situarla hacia el 800-780 a.C.

En estos últimos años, el numeroso material fenicio y autóctono recogido bajo el nivel freático, en los limos de un suelo muy transformado de la ciudad de Huelva, ha centrado el problema de las navegaciones fenicias más antiguas a Occidente, anteriores a la fundación de Cádiz, y el de la cronología. La variedad de formas recogidas y su cantidad, aunque no procedan de estratos y contextos definidos, han dado un vuelco sustancial a los inicios de la colonización fenicia (Gonzalez de Canales et al., 2004 y 2009). El material, contrastado con el de la Edad del Hierro de Tiro principalmente, se sitúa entre el 900 y 770 a.C., un espacio quizás excesivo, de muchas generaciones, que no parece probable. Tres fechas obtenidas en la universidad de Groningen, con huesos de ganado, aportaron una fecha media calibrada entre el 930 y 830 a.C. (Nijboer et al., 2006). Resultados que no concuerdan con la cronología convencional de Tiro ni con el Geométrico Medio II Ático, que constituye uno de los problemas a solventar, y que modifica el tiempo de la Edad del Hierro mediterránea. El obstáculo se halla en los cambios tan importantes hacia cronologías muy altas de las cerámicas geométricas griegas y las de Eubea, frecuentes en Huelva. Sin embargo, Fantalkin (Fantalkin et al., 2011) sitúa el conjunto a fines del Hierro IIA e inicios del IIB, es decir, a fines del siglo IX y primera mitad del VIII a.C. Otros investigadores, que analizan las edades del Hierro en el Levante mediterráneo (Gilboa, 2013) los ubican a lo largo del siglo IX a.C., y la mayoría en su segunda mitad. En mi opinión, la fecha más probable, es la de los últimos decenios del siglo IX a.C.

Se poseen dataciones absolutas de algunos yacimientos peninsulares (Mederos y Ruiz, 2006), diversas y dispares, que no merece exponer aquí por la discusión que conllevan y que no conducen a puntos positivos y clarificadores. Unos trabajos de M. Torres (Torres, 1998 y 2008), llega a conclusiones más acertadas en mi opinión. Y sitúa el inicio de la presencia fenicia en el Mediterráneo Occidental entre el 825 y 800 a.C. Huelva es algo anterior. A conclusiones similares han llegado otros investigadores (Botto, 2005; Nigro, 2014), conocedores de los problemas en Oriente y la presencia de los semitas en el Mediterráneo central.
En resumen, y en lo que atañe a los primeros contactos y fundaciones occidentales, Huelva es el punto más antiguo, el que interesó en sus primeras navegaciones a los fenicios para sus objetivos comerciales y obtención de plata, antes de la fundación de Gadir. Lo que debió suceder durante unos decenios antes del 800 a.C., anterior a la fundación de Cartago, y el contexto material lo avala suficientemente. El poblado y lugar de culto de Rebadanillas en Málaga se debió fundar en ese tiempo o muy poco después de Huelva (Sánchez et al., 2012). Otro tema es Utica, fundada antes que Cartago. Las investigaciones efectuadas en el yacimiento nos proporcionarán datos fundamentales. $\mathrm{Y}$ algunos materiales ya conocidos anuncian su antigüedad (López et al., 2016). En el 800 a.C., como fecha más antigua, se debieron fundar Cádiz y el CDB, y varias colonias y factorías de la costa mediterránea, como el Morro de Mezquitilla (Schubart y MaassLindemann, 2017).

Es ahora cuando el texto de Estrabón (III, 5, 5) sobre la fundación de Cádiz se puede comprender con visión histórica y arqueológica más ajustada en el espacio y en el tiempo, con los matices y giros que son propios de las investigaciones en las zonas citadas. Se mencionan tres viajes a Occidente. El primero no traspasó el Estrecho de Gibraltar, quedándose en su afán exploratorio, en la ciudad de los exitanos, que se supone situada en Almuñécar, pero pudo haber sido Málaga. En una navegación posterior, llegaron a Onoba, habitada por una población importante del Bronce final. Y en la tercera fundaron Cádiz. Al margen del oráculo iniciador e indicador de estas navegaciones y de los sacrificios propiciatorios, la arqueología halla vestigios importantes en Málaga -Rebadanillas-, sin traspasar el estrecho, en Huelva ciudad, a distancia considerable de él, donde hablan los restos arqueológicos de modo explícito. Un espacio costero extenso donde se fundaron las colonias semitas.

$\mathrm{Y}$ finalmente se quedaron en un lugar de grandes posibilidades por sus recursos productivos, próximo al comercio de los metales, por la intensidad del poblamiento para el comercio y mano de obra, y cerca de un estuario que permitía navegaciones al interior, y en menor medida el Guadalete, posiblemente conectado con él en un punto más alto del río. Los tres viajes parecen ciertos, si se persiguen los rastros arqueológicos. La diferencia estriba en que en la zona mediterránea y en Huelva había establecimientos, fue más que una llegada ocasional, 
un sacrificio y un veredicto negativo. Los augurios desfavorables que obligaron el regreso a Tiro no se corresponde con los datos de la arqueología. Pero no es el tema importante. Lo que interesa es conocer que Cádiz se fundó tras un conocimiento del territorio ya navegado de los fenicios, de Almería hasta Huelva, eligiendo el más propicio. El lugar elegido, tras un análisis de posibilidades productivas y de mercado, fue Cádiz. Es decir, la Bahía en su conjunto. Estrabón recogió fuentes que describían estos periplos, pero atendiendo sólo a la fundación y antigüedad de Cádiz, pues de ensalzarla y darle contenido histórico se trataba, desde la perspectiva de muchos años después y de los inicios de la propaganda romana en la apropiación de Iberia. Lo que más se aleja de esta historia es la fecha de su fundación, en 1100 a-C. y su relación con Troya, su aspecto mítico y su referencia obligada. Algo muy normal. Cuando se construye un poderoso y mítico vínculo histórico, se acude al mito y, en este caso, a lo que Troya representó por Homero que le dio contenido. Se trata de anclar al pasado, como referencia suprahumana, el origen de la ciudad, que es el de los hombres y su desarrollo social, religioso y económico.

Pero ¿Qué es Gadir y su espacio? (Figuras 3, 5 , 14 Y 15).

No es una pregunta ociosa ni fútil. Es necesaria tras las cuestiones que he expuesto en las páginas previas, con las viejas preguntas y los nuevos temas que han surgido en el curso de las investigaciones en estos últimos años. El CDB era más conocido, pese a que todavía no se han publicado con detalles todos sus resultados. Pero lo conocido ya anunciaba que la fundación de Gadir, conocida en las fuentes escritas, debía ser repensada desde otras perspectivas, en una amplitud espacial más extensa y en otro tiempo, contando con la ciudad costera del CDB y con su entorno humano y económico. En templo de Melqart es inherente y necesario en cualquier fundación fenicia de alto grado de interés político y simbólico.

Quizás los griegos, al mencionar TA GADEIRA se referían a esto, a un espacio plural, no reducido al de la pequeña isla de Eritia. Así lo vio, sin conocer los resultados recientes en Cádiz y la publicación de Huelva, S. Moscati en su "Grande Cadice", el eje central en cuya órbita giraba todo. Nadie le resta importancia, pero algunos vemos en este término una suma más amplia en un espacio más extenso y en categorías funcionales diferentes, como expuse hace muy poco (Ruiz Mata, 2016), y en este trabajo lo matizo y amplio. La veo plural, en todo el ámbito de la Bahía, con núcleos bien definidos estratégicamente situados y funcionalmente estructurados. Me la imagino activa en tres puntos principales: la pequeña isla de Cádiz, en la que se estableció un núcleo urbano en escaso espacio; el templo de Melqart, en las puertas de este núcleo político, como representación en Occidente de la ciudad de Tiro y para la supervivencia étnica, ritual e ideológica, también cultural, lo que entraña un templo en lejanas tierras; y la ciudad del CDB, ciudad y puerto, que controlaba muchos de los aspectos productivos y económicos que fueron la razón de la fundación de Gadir. A la que posiblemente haya que añadir el $\mathrm{CdCa}$ en Chiclana, junto al río Iro, cercana al templo con el que debió mantener una relación estrecha y especial. Futuras excavaciones nos van a proporcionar con seguridad datos más precisos de función $y$ de fechas. Veamos unos aspectos entre ambas fundaciones, TC en Eritia y CDB enfrente, en tierra firme, y las ventajas de la elección fenicia en la Bahía, cuya isla inhóspita no ofrecía expectativas atrayentes para el fenicio comerciante a la busca de productos y mercados.

- Como dije, siguiendo a Estrabón y a los datos arqueológicos, la fundación de Gadir es la consecuencia lógica de los dos viajes previos en el espacio costero meridional, quedando al margen en principio la Bahía gaditana y el estuario del Guadalquivir en el proyecto fundacional, según los textos. Hay exploraciones para ver los lugares convenientes. Estas navegaciones, en la segunda mitad del siglo IX a.C., fructificaron en fundaciones -el ejemplo conocido de Rebadanillas- y mucho más lejos, en la costa atlántica, Huelva ha deparado una importante documentación de contactos y negocios comerciales relacionados con la plata a través del núcleo poblacional indígena de Huelva. Se navegó un espacio que, con el tiempo, sería el del control fenicio y tartésico, desde el que se extendieron los semitas hasta el interior del suroeste peninsular, norte de Argelia y Marruecos y por Portugal hasta Lisboa. En estos primeros momentos, arqueológicamente explícitos e importantes, el oráculo, simple protocolo, no se cumplió por la adversidad de los ritos que debían ser favorables para la fundación prevista desde Tiro. En el tercer intento se funda Cádiz, tras navegaciones durante unos decenios que permitieron reconocer el terreno y todas sus posibilidades 
para los objetivos fundacionales, comerciales y productivos. No es difícil entender el texto así. Ahora con elementos arqueológicos explícitos estas razones resultan más lógicas y acertadas. Y todo encaja, textos y arqueología.

- Pero ¿por qué la Bahía gaditana y en un islote sin grandes atractivos?. Creo que es el lugar más apropiado para establecer un núcleo colonial y centro de los intereses de Tiro en el atlántico. Los factores que propiciaron la creación de Gadir tras unos años de tanteo y de conocimiento empírico del lugar son evidentes: 1) el seguimiento de un modelo ya establecido en algunos lugares costeros, como la propia Tiro; 2) la cercanía al estuario del Guadalquivir navegable hacia el interior más arriba de Sevilla, que favorecía el comercio, e incluía a los esteros navegables; 3) la SSC, donde desembocaba el Guadalete, favoreció la fundación del $\mathrm{CDB}$, como el núcleo fenicio consistente en la costa; 4) la producción de plata en la región minera de Aznalcóllar, al margen del núcleo de Riotinto, (Hunt, 1995 y 2005), desde donde llegaba al CDB; 5) la campiña y sus posibilidades productivas agropecuarias, que muestra su intenso poblamiento desde la Edad del Cobre; 6) los factores productivos agropecuarios favorecieron una densa población del Bronce final, repartida junto a la costa del estuario y del Atlántico, esteros y la campiña, que los fenicios consideraron para sus fines comerciales, de intercambios y mano de obra para las nuevas tecnologías para la producción. Asunto importante, porque sin población no hay colonización, cuyo motivo inicial fue el comercio.

Estas ventajas no se hallaban en toda su plenitud en Huelva y costa malagueña. Huelva ofrecía evidentemente plata, un producto básico del comercio fenicio, pero su población del Bronce Final era más restringida que la del Bajo Guadalquivir y Cádiz. Y de hecho no se advierten fundaciones fenicias en el entorno de Huelva capital, ni que fuese fundada por fenicios, sino integración en los cabezos ocupados por los autóctonos del Bronce final (Gómez, 1996). Y en el caso de Málaga sucede algo parecido, con menos densidad poblacional indígena en el entorno de las factorías fenicias y barreras de montañas que impedían un tráfico fluido y sin grandes obstáculos (García, 2007).

La isla de Cádiz, o islas, dividida por un canal o parte de ella (Arteaga et al., 2001), no se eligió por sus atractivos productivos, por los vientos y la escasez de agua, que permitía abastecer a una escasa población. Se consideró su posición estratégica y simbólica, una isla, baja y sin defensas, frente a una costa que poseía todo lo que se demandaba para una colonización con éxito económico y expansivo. De aquí, la existencia del CDB. Sin un núcleo costero en un medio tan favorable, la historia gaditana sería distinta, probablemente no hubiese sido. Esa dualidad era necesaria, junto al templo y sus ritos, el lugar de cohesión étnica y cultural que garantizaba la existencia de Tiro en ese lugar occidental, lejos de su patria de origen. El templo de Melqart, protector de Tiro y de sus navegantes, se hallaba en el extremo oriental de la isla, a $18 \mathrm{~km}$ de distancia de su núcleo urbano, lo que denota independencia de la ciudad y el lugar crucial de referencia religiosa de la Bahía, de la entrada simbólica al espacio semitizado. Muy poco después, el templo de Melqart y los de Cádiz se emplearon como medio efectivo de ocupación ideológica del espacio a través de la religión, la implantación de sus dioses y de sus ritos, que es el modo más eficaz de expansión e integración, como se advierte hasta en los lugares más distantes. Si tuviésemos delante un mapa de la situación de los templos, santuarios y lugares sagrados y las fechas veríamos con claridad este espacio religioso, que fue la estrategia fenicia para la orientalización occidental por medio de la ideología, que sólo podía ser religiosa en ese tiempo, al imbricarse con la política, economía y las costumbres. Es su importancia como factor de cohesión para los fenicios lejos de su patria y como estrategia ideológica de expansión colonial (Manning, 2010; Cardete del Olmo, 2017; Tortorelli, 2015; Santiago, 2016).

- Estos factores son necesarios para comprender la decisión en la elección del lugar donde se fundó Gadir en los tres puntos indicados: en la isla Eritia, el CDB junto al Guadalete y el templo de Melqart en el islote de Sancti Petri, ahora muy reducido, pero que debió ser de mayor dimensión en su tiempo a juzgar por los hallazgos subacuáticos (Garcia y Bellido, 1963). La naturaleza, el hombre y el tiempo le han despojado de su paisaje originario, reduciéndolo a un islote mutilado. Y en cuanto a tamaños, Cádiz y CDB difieren en sus dimensiones, que debió tener un significado en su tiempo, oscurecido por la excesiva prevalencia de las fuentes que no siempre son generosas con los datos. Se trata de un aspecto importante que contradice por completo la visión de S. Moscati y la de otros investigadores, que tenían fijo este patrón (Corzo, 1992). En este sentido, merece conocer la opinión de Corzo sobre la población en Cádiz. Supone, optimista, que en 
época fenicia plena, que son la de los siglos VIII-VI a.C., la población debió alcanzar 20.000 habitantes, "similar a las ciudades importantes del momento" (Corzo, 1992, 46). La población se mantuvo estable, siguiendo a este autor, durante los siglos $\mathrm{V}$ a III a.C. Y en época de Augusto llegaría a 50.000. Es la aspiración exagerada de los que han calculado más desde el deseo que desde los datos objetivos que no engañan, que son las viviendas en el espacio.. $\mathrm{Y}$ se alejan mucho de estas cifras exageradas. Las dimensiones urbanas, cuando las hay, muestran una ciudad muy pequeña en todos los tiempos antiguos. Así lo recogió Estrabón en el pasaje III, 5, 3. Si hacemos cálculos espaciales, y posibilidades para el abastecimiento de agua, disponiendo sólo de un pozo, el TC y sus aledaños estarían habitados por una población que no sobrepasarían 300 ó 400 habitantes. Y por su carácter portuario y sus templos, alcanzarían varios cientos más no estables. El CDB, a través de su espacio y la medida media de sus viviendas, alcanzaría más de 1.500 habitantes en su hábitat intramural, en su relación número viviendas, dimensiones y espacio.

Y regresando al paradigma mostrado por Moscati, que considera la fundación del $\mathrm{CDB}$ en función de Cádiz, como puerto de la ciudad, no parece tan evidente ni tiene sentido con los nuevos datos. Creo que desde el comienzo se pensó en la fundación dual, sin subordinación, sino como estrategia de fundación funcional y práctica. Los fenicios miraban al mismo tiempo a la isla desierta de Cádiz y a la tierra firme de enfrente, pensando desde el inicio la dualidad. La ciudad de Cádiz, si tomamos como núcleo el TC, debió ser de escaso tamaño, poco más de $1 \mathrm{Ha}$ o $1.5 \mathrm{Ha}$., al quedar limitada por la CA, de la que la separa unos $125 \mathrm{~m}$., por el canal, poco más de 80 m., y calle del Marqués del Real Tesoro $n^{0} 13$. Al norte, a uno $310 \mathrm{~m}$., las excavaciones efectuadas en la PSA proporcionaron un panorama arqueológico muy diferente, donde no se hallan restos fenicios. CA y CdC se han considerado zonas periurbanas (Gener et al., 2014), con actividades muy diversas -hito sagrado funerario y trabajos pesqueros-, y en ningún caso se perciben habitaciones. De modo que el núcleo urbanizado queda constreñido a la extensión del espacio que he indicado (Figuras 14 y 15). Además, el problema continúa con otra pregunta esencial ¿donde se instalaron, dónde se hallan las viviendas púnicas, tras muchos puntos perforados en el casco antiguo de la ciudad?. Quizás se hallen en algún lugar todavía desconocido, pero en un es- pacio muy reducido, del que aún no se poseen datos suficientes. Y la población estable debió ser escasa, como he dicho.

Es así como lo expresa Estrabón (III, 5, 3) en la descripción de la ciudad, en época ya romana: “...y puesto que no habitan una isla grande ni dominan extensas tierras en la parte opuesta de la costa firme, ni poseen otras islas, la mayoría viven en el mar siendo pocos los que residen en sus casas o están en Roma...; su isla no mide más de 100 estadios de longitud, siendo su anchura a veces de un estadio. En un principio vivían en una ciudad muy pequeña; mas Balbo...levantoles otra que llaman "nueva"; de ambas surgió Didima, cuyo perímetro, aunque no pasa de veinte estadios, es lo suficientemente grande para no sentirse agobiada de espacio; efectivamente, en ella residen pocos, ya que la mayoría pasan en la nueva gran parte del tiempo, o viven en la tierra firme frontera, y sobre todo en la vecinita isla, porque ésta es fértil; tanto es así que, agradándoles el lugar, han hecho de la islita como una "antípolis" de Dídime; pero en proporción son pocos los que habitan en ella y en el arsenal que les ha construido los Balbos en la tierra firme frontera. La ciudad yace en la parte occidental de la isla...". Un texto muy elocuente y cierto en época romana.

Si esta es la situación en época romana, y la arqueología no lo desmiente, lo mismo debió suceder épocas fenicias y púnicas. Me he referido al tamaño de la ciudad fenicia, pero no la de época púnica -siglos V-III a.C.-, no reflejada en la secuencia del TC ni en el amplio espacio excavado en la PSA ni en la CA y CdC, ignoramos donde pudo situarse la ciudad contemporánea de los sarcófagos antropoides y de muchas tumbas de los siglos V-III a.C., que sugieren emplazamientos de cierta envergadura. Lo mismo sucede en siglos III-I a. C. E incluso en época romana, que no sobresale por sus lugares públicos y privados, viviendas, mosaicos o indicios artísticos que sugieran la existencia de una ciudad rica y floreciente. Y en cambio sobresale el teatro por su tamaño y capacidad, que no se corresponden con las necesidades de una gran ciudad. Sólo se explica por ser el teatro de un amplio espacio de la Bahía y de la campiña, y por el desarrollo de la propaganda política en los momentos claves de la implantación romana. Estrabón habla también de los templos, del Kronion y del Heracleion, pero situado no menciona el templo de Astarté-Venus.

De lo que se infiere que en ninguna época hubo una ciudad de dimensiones que se esperan de un 
centro político y comercial importante. Los enterramientos, a partir del siglo VI a.C. -los más antiguos conocidos, a excepción de alguno del s.VII a.C., ocupan un gran espacio sumados los núcleos en que se hallan, y repartidos por la isla están los centros de producción relacionados con actividades pesqueras. Y en época romana sobresale el teatro de gran capacidad, que no se corresponde con el número de habitantes que debió residir en la isla, quizás en torno a dos mil. Este aparente desorden sólo se explica por el carácter simbólico-religioso y sagrado que tuvo la isla desde sus comienzos fenicios. Los templos de Astarté y Cronos debieron ser puntos obligados para el navegante y de asistencia a los ritos y a las fiestas a los que habitaban en tierra firme. Y el teatro es la expresión de todo ello, pues es el punto de diversión y de la política. Un teatro para la Bahía. Lo que explica su tamaño. El templo de Melqart, alzado en el islote, es la puerta de entrada abierta a la compleja y plural estructura del estado gaditano y del rico país del sudoeste peninsular y atlántico. En época posterior, en los siglos VI-V a.C. se unió la isla de San Fernando.

- El CDB ofrece otro esquema, que se ha podido advertir por su abandono a finales del siglo III a.C., porque no hubo ocupación romana después y porque el río cambió su rumbo y destino, y abriéndose paso entre los marjales del nuevo paisaje naciente alcanzó las cercanías donde hoy se erige y extiende la ciudad de El Puerto de Santa María. Hoy tenemos, pues, a la vista los elementos en los que convivieron fenicios y después turdetanos durante quinientos años. Y con estas ventajas se ven con más claridad las diferencias con la población residente en la isla gaditana. Los cálculos justifican una población casi estable, desde sus comienzos fenicios

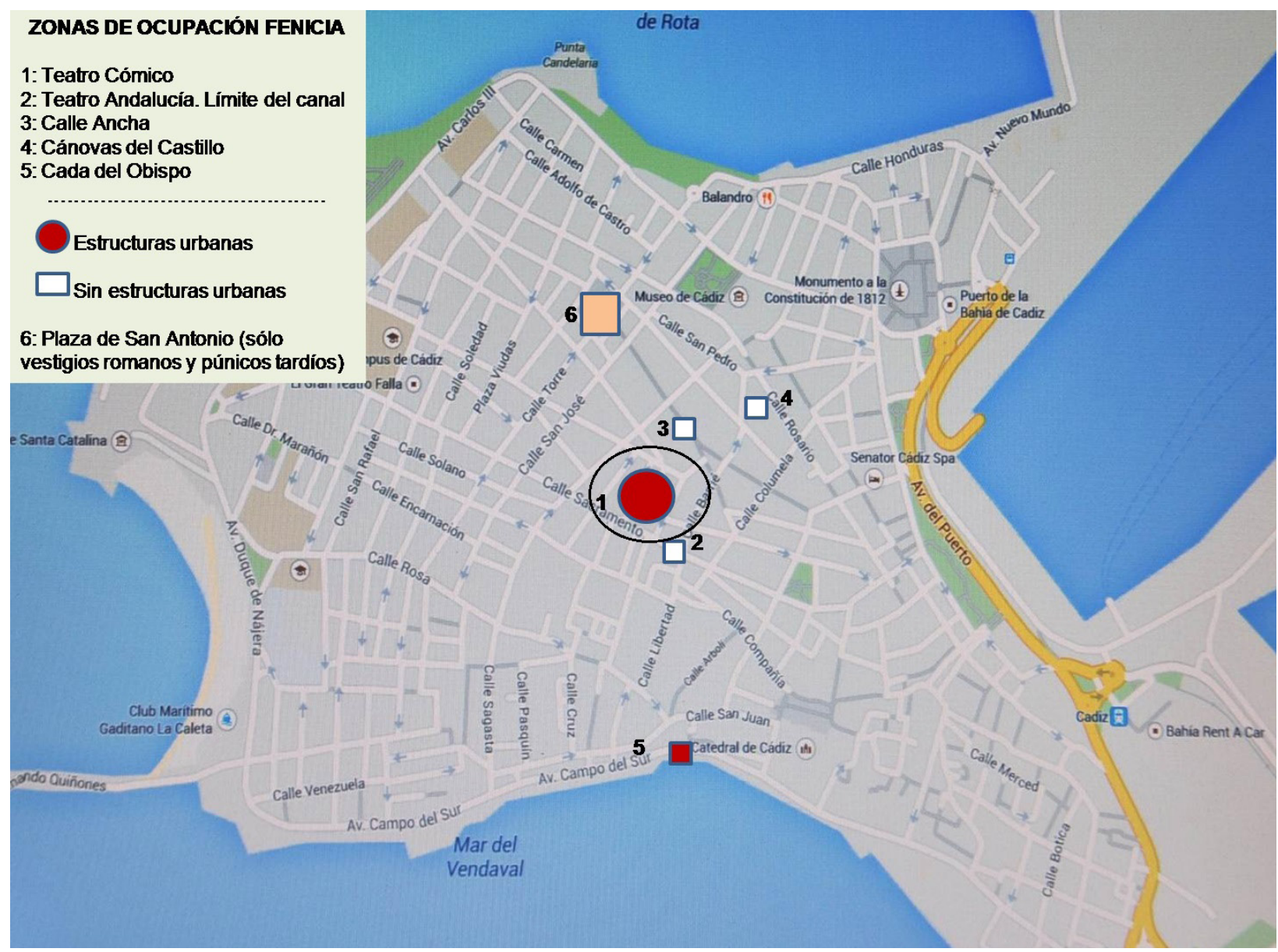

Figura 14. Plano de Cádiz con indicación de las actuaciones en zonas fenicias arcaicas (foto de base Google Earth modificada por D. Ruiz Mata) 
en el siglo VIII a.C., entre 1250 y 1500 habitantes, quizás 2000 en el siglo III a.C. Estamos en una ciudad de 6/7 Ha, más necrópolis, puerto y zonas industriales, que alcanzan $400 \mathrm{Ha}$. Lo que la sitúa en las magnitudes de las ciudades fenicias y bíblicas.

En cuanto a la ciudad, se trata de un espacio bien elegido al pié de la sierra y junto al río, rodeada de una recia y amenazadora muralla, con una línea de foso de $18 \mathrm{~m}$ de anchura y $3 \mathrm{~m}$ de profundidad. La figura 11 refleja sus medidas. Al norte, la necrópolis (Figura 8), en una extensión 1000 × 940 m, prácticamente el área del caso urbano gaditano o la de la isla Eritia. Cerca de la ciudad, en su flanco oriental, el puerto, y poco más abajo, a unos $300 \mathrm{~m}$., la zona portuaria, en mi opinión, y al norte, una zona abierta destinada tal vez a zona de trabajo, de almacenamiento de mercancías y al servicio del puerto, y de protección de los barcos en épocas no navegables. Y en la cima de la sierra, ha quedado, tras horadarla con saña para el uso como cantera por su piedra calcarenita, una zona amesetada de 700 x 300 m., que fue la expansión industrial de la ciudad a lo largo del siglo III a.C., hasta su abandono. Ha perdido más de un tercio de su extensión, y debió tener al menos 4 ó $5 \mathrm{Ha}$ ocupados, doblando la superficie de la ciudad. Es posible que se hallen restos arqueológicos al sur y al oeste de la ciudad, pues de una covacha en esta zona -actualmente destruida-, se han recogido fragmentos cerámicos arcaicos. Quizás fuese una cueva-santuario, similar al que los fenicios ocuparon en Gorham, en Gibraltar (Gutiérrez et al., 2013).

Hablamos de un espacio urbano amplio y estructurado. Lo que no advertimos en Cádiz, por la ciudad moderna que constituye a veces una tapadera infranqueable y por el sentido de la distribución de sus restos que no se entiende desde una visión clásica de una ciudad, un modelo complejo y difícil de entender porque no hemos captado -es mi casoel sentido, la elección práctica y la función especí-

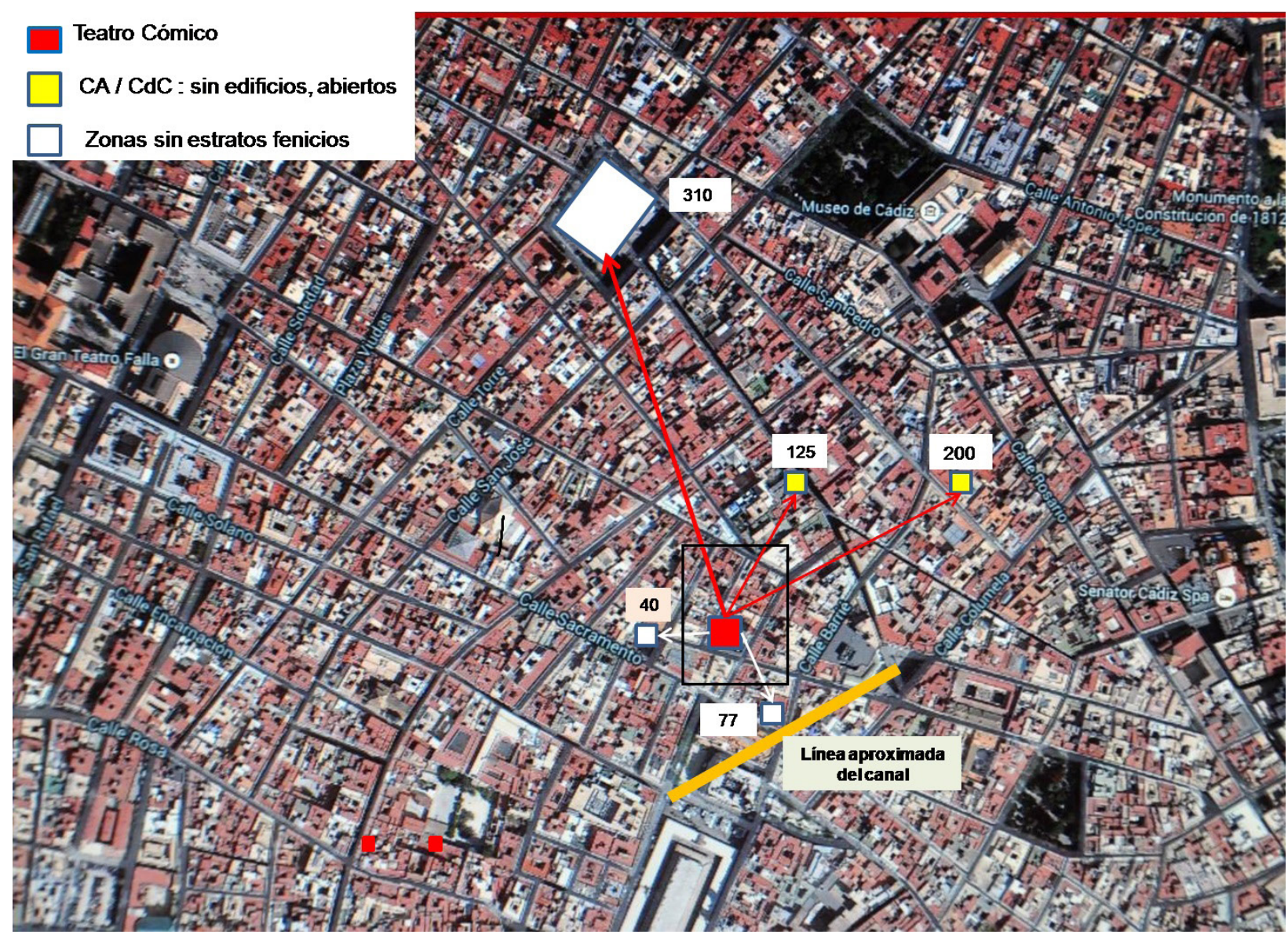

Figura 15. Foto aréa con indicación de las zonas arqueológicas fenicias arcaicas y las distancias desde el TC (Google Earth, modificado por Diego Ruiz Mata) 
fica del espacio desde su fundación fenicia. Pese a todo, nunca debió ser muy extensa. Tal vez algún día, recompuesto el puzzle, aparezca un esqueleto perfectamente organizado, según su función y los significados que los fenicios imprimieron en ella. Es difícil. No se trata de una estructura normalizada, sino especial en razón de unos espacios simbólicos que desconocemos, y que la determinaron.

La "Grande Cadice dei fenici" de S. Moscati la sigue siendo, pero no desde la supremacía y unicidad, sino desde la pluralidad funcional, cuyo esquema hizo grande el concepto histórico de Gadir. Por sí misma, no hubiese prosperado en condiciones tan poco favorables. Y termino repitiendo lo que escribí hace tres años (Ruiz Mata, Pérez y Gómez, 2014, 315) sobre este tema, que ahora expreso con más amplitud y detalles. Lo que entiendo por Cádiz-Gadir en sus siglos primeros de actividad es la conjunción del templo de Melqart, una suerte de Tiro en Occidente, que mantenía día a día la cultura, costumbres, religiosidad y cohesión social y étnica de los tirios desplazados y de los navegantes asiduos u ocasionales que llegaban en sus barcos a sus santuarios y puertos, con un baluarte -CDC en Chiclana- quizás relacionado con los servicios que requería el templo, el CDB en la costa, con sus actividades políticas, comerciales y productivas, y sus relaciones diplomáticas e integradoras con las poblaciones autóctonas de su entorno, esencial para el éxito económico, y Cádiz, que adquirió, en su carácter simbólico y representativo de Tiro, su patria de origen, un papel político y religioso, que mantuvo a lo largo del tiempo. Cádiz fue una red plural de centros funcionales y cohesionados de la Bahía, y en el sentido holístico, el resultado total de la suma de sus partes. En decir, el espacio que ofrece el mapa con el círculo de la figura 1 es lo que se debe entender como Gadir. Así la he entendido. Hasta ahora, no hallo razones contrarias.

\section{BiBLIOGRAFIA}

Abad, L. (1975), El Guadalquivir, vía fluvial romana, Sevilla.

Abía, A.M. (2010), "El sarcófago antropomorfo femenino de época púnica: ¿sacerdotisa de Gadir?, Las necrópolis de Cádiz. Apuntes de arqueología gaditana en homenaje a F.J. Sibón Olano (A.M. Niveau de Villedary y V. Gómez Fernández, Eds.), Diputación Provincial de Cádiz-Universidad de Cádiz, 119-141.

Almagro-Gorbea, M., López, E., Mederos, A. y
Torres Ortiz, M. (2010), "Los sarcófagos antropoides de la necrópolis de Cádiz”, Mainake XXXII, I, 357-394.

Alvar, J. - G. Wagner, C. (1985), "Consideraciones históricas sobre la fundación de Cartago", Gerión 3, 79-95.

Alvárez Rojas, A. (1993), "Sobre la localización del Cádiz fenicio”, Boletín del Museo de Cádiz V, 17-30.

Alvárez Rojas, A. y Aranda Linares, C. (19931994), "Bibliografía de Cádiz en época fenicia y romana”, Boletín del Museo de Cádiz 6, 5366.

Apple, R. (2014), "The Pillars of the Temple", Jewish Bible Quaterly, vol 42,4, 221-228

Aranegui, C., López Beltrán, M. y Vives-Ferrándiz, J. (2011), "The Strait and Beyond: local communities in Phoenician Lixus", Ceramics of the Phoenician-Punic World. Collected Essays (Claudia Sagona, Ed.), Ancient Near East. Suppl. 36, Leuven-Paris-Walpole, M.A., 297326.

Anderson, W. (1981), A Stratigraphy and Ceramic Analysis of the Late Bronze and Iron Age Strata of Sounding Y at Sarepta (Sefarand, Lebanon), Tesis doctoral 1979, University of Pennsylvania, London.

Aubet, M.E. (1986), "La necrópolis de Villaricos en el ámbito púnico peninsular”, Homenaje a Luís Siret (Cuevas de Almanzora 1984), Sevilla, 612-624.

(1993), Tiro y las colonias fenicias en Occidente, Crítica, Barcelona, ed. revisada.

Aubet, M.E., Carmona, P., Curià, E., Delgado, A., Fernández, A.- y Párraga, M. (1999), Cerro del Villar 1. El asentamiento fenicio en le desembocadura del río Guadalhorce y su interacción con el hinterland, Arqueología Monografías Memorias 5, Sevilla.

Arteaga, O., Barragán, D., Roos, A.M. y Schulz, H.D. (2015), "La geoarqueología en el paleoestuario del río Guadalquivir desde la Prehistoria hasta el Mundo Antiguo. La fundación del puerto de Itálica", Arqueoworld 2014, Actas del Congreso, Vol. I, Fundación Tierras del Sur, Sevilla, 20-51.

(2016), "Primicia cartográfica del río Guadalquivir hace 6500 años”, Revista Atlántica-Mediterránea de Prehistoria y Arqueología Social, 18, 139-161.

Arteaga, O., Kölling, A. Kölling, M., Roos, A.M., 
Schulz, H. y Schulz, H.D. (2001), "Geoarqueología urbana de Cádiz. Informe preliminar sobre la campaña de 2001". AAA, III.1, 27-40.

(2001 b), "El puerto de Gadir. Investigación arqueológica en el casco antiguo de Cádiz”, Revista Atlántica-Mediterránea de Prehistoria y Arqueología Social, 4, 345-415.

Arteaga, O. y Menanteau, L. (2004), "Géoarchéologie comparée de deux estuaries de l'Atlantique: la Loire (France) et le Guadalquivir (Espagne)". Les Dossiers d'Ethnopole. Pour une géoarcheologie des estuaires (L. Menanteau y A. Gallice, coords.), Aestuaria 5, 23-45.

Arteaga, O. y Roos, A.M. (1992),”El proyecto geoarqueológico de las Marismas del Guadalquivir. Perpectivas arqueológicas de la campaña de 1992”, AAA (II), 329-339.

(2002), "El puerto fenicio-púnico de Gadir. Una nueva visión desde la geoarqueología urbana de Cádiz”, Spal 11, 21-39.

Arteaga, O., Schulz, H. y Roos, A.M. (1995), "El problema del Lacus Ligustinus. Investigaciones arqueológicas en torno a las marismas del Guadalquivir", Tartessos 25 años después 19681993, Actas del Congreso Conmemorativo del V Symposium Internacional de Prehistoria Peninsular, Jerez de la Frontera, 99-135.

(2008), "Geoarqueología dialéctica en la Bahía de Cádiz”, Geoarqueología y Proceso Histórico en la Bahía de Cádiz (O. Artega y H.D. Schulz, eds.), Revista de Arqueología AtlánticaMediterránea de Prehistoria y Arqueología Social, 10, 21-116.

Arteaga, O. y Schulz, H. (2008): "Geoarqueología y Proceso histórico en la Bahía de Cádiz”. Revista Atlántica-Mediterránea de Prehistoria y Arqueología Social 10, pp. 7-20.

Barragan, D. (2016), "La línea de costa flandriense en el Paleoestuario del Río Guadalquivir (c. 6500 BP)”, Revista Atlántica-Mediterránea de Prehistoria y Arqueología Social, 18, 111138.

Bartoloni, P. (2012), "I fenici a Rachgoun", SCE$B A, X, 67-91$.

Bats, M. (2012), "Les Phocéens, Marseille et la Gaule(VII'-III' s.v.J.-C.)”, Pallas, Revue d'Études Antiques, 89, 145-156.

Belén, M., Rut, A., García, M.C., Roman, J.M. y Vázquez, J. (2014), "Carmona tartésica entre la tradición y el cambio". Fenícios e Púnicos, por terra e mar, Actas do VI Congreso Inter- nacional de Estudos Fenícios e Púnicos, Estudos e Memorias, 6, vol.2. Uniarq, Lisboa, 640-649.

Bikai, P.M. (1978), The pottery of Tyre, Warminster, Wilts.

(1987), The Phoenician Pottery of Cyprus, Nicosia.

Blanco, A. y Corzo, R. (1981), Der neue Anthropoide Sarkophag von Cádiz”. Madrider Mitteilungen, 22, 236-243.

Blanco, A., Luzón, J.M. y Ruiz, D. (1969), "Panorama tartésico en Andalucía occidental”, Tartessos y sus problemas (J.Maluquer de Motes, ed.), VSIPP, Barcelona, 119-162.

Blanco, A. y Luzón, J.M. (1975), "Resultado de las excavaciones del poblado de Riotinto (Huelva)", Huelva, Prehistoria y Antigüedad, Madrid, 235-247.

Blázquez, J.M. (1969), "Fuentes griegas y romanas referentes a Tartessos". Tartessos. V Symposium Internacional de Prehistoria Peninsular. Universidad de Barcelona, 91-110.

(1975), Tartessos y los orígenes de la colonización fenicia en Occidente. Salamanca.

Blázquez, J.M., Luzón, J.M., Gómez, F. y Claus, K. (1970), Las cerámicas del Cabezo de San Pedro. Huelva, Huelva arqueológica, I, Huelva.

Blázquez, J.M., Ruiz, D., Martín de la Cruz, J.C., Remesal, J., Ramirez, J.L. y Clauss, K. (1979), Excavaciones en el Cabezo de san Pedro (Huelva). Campaña de 1977, Excavaciones Arqueológicas de España 102, Madrid.

Botto, M. ((2005), "Per una riconsiderazione della cronologia degli inizi della collonizazione fenicia nel mediterraneo centro-ocidentale", Oriente e Occidente: Metodi e discipline a confronto. Riflessioni sulla cronologia dell'età del ferro italiana (A cura di G. Bartoloni e F. Delpino), Pisa-Roma, 579-630.

Brandherm, D. y Krueger, M. (2017), "Primeras determinaciones radiocarbónicas de la necrópolis de Setefilla (Lora del Río) y el inicio del período orientalizante en Andalucía Occidental", Trabajos de Prehistoria, 74/2, 296-318.

Bueno, P. (2014), "Un asentamiento del Bronce Final-Hierro en el Cerro del Castillo, Chiclana (Cádiz)”, Los fenicios en la Bahía de Cádiz: Nuevas investigaciones (M. Botto, Ed.), Collezione di Studi Fenici, 46, 225-251.

Bueno, P. y Cerpa, J.A. (2008), "Un nuevo enclave descubierto en la Bahía de Cádiz”, Spal 17, 169206. 
Bueno, P., García-Menárguez, A. y Prados, F. (2013), "Murallas fenicias de Occidente. Una valoración conjunta de las defensas del Cerro del Castillo (Chiclana, Cádiz) y del Cabezo del Pequeño Estaño (Guardamar, Alicante)", $\mathrm{He}$ rakleion, 6, 27-75.

Bunnens, G. (1979), L'expansion phénicienne en Mediterranée, Bruxeles-Rome.

Cabrera, P. (1990), "El comercio foceo en Huelva: cronología y fisonomía”, Huelva Arqueológica, $X-X I$ (3), 41-100.

(1994), "Cádiz y el comercio de productos griegos en Andalucía Occidental durante los siglos V y IV a.C.”. Trabajos de Prehistoria 51, nº 2, 89101.

(1995), “Cerámicas griegas en Tartessos: su significado en la costa peninsular desde Málaga a Huelva”, Tartesos 25 Años Después 19681993, Actas del Congreso Conmemorativo del V Symposium Internacional de Prehistoria peninsular, Jerez de la Frontera, 387-399.

(1998), "El comercio turdetano a través de las cerámicas griegas”, La colonización fenicia en la Bahía de Cádiz a través del Castillo de Doña Blanca. Puerto de Santa María (D. Ruiz Mata, Ed.), Memoria inédita, Consejería de Cultura, Sevilla, 473-481.

Campos, J.M.(1986), Excavaciones arqueológicas en la ciudad de Sevilla: el origen prerromano y la Hispalis romana, Monte de Piedad y Caja de Ahorros, Sevilla.

Carayon, N.(2011), "Note sur l'organisation spatiale des agglomerations insulaires phéniciennes et puniques", Mediterranée, 117, 111-114.

Carayon, N., Marriner, N. y Morhange, Ch. (2011), "Geoarchaeology of Byblos, Tyre, Sidon and Beirut”, Rivista di Studi Fenici, XXXIX/1, 45-55.

Cardete del Olmo, M.C. (2017), "La religión como criterio de identidad en la Grecia Clásica”, Gerión, 35, 1, 19-40.

Caro Bellido, A. (1998), Lebrija y el Bajo Guadalquivir: pelogeografía y fuentes clásicas grecolatinas, Lebrija, Agrija.

Carriazo, J. de Mata (1973), Tartesos y El Carambolo, Madrid.

Chiera, G. (1981), "Su un nuevo sarcofago antropoide scoperto a Cadice”, Rivista di Studi Fenici, 9 (2), 211-216.

Córdoba, I. y Ruiz Mata, D. (2005), "El asentamiento fenicio arcaico de la calle Cánovas del
Castillo (Cádiz). Un análisis preliminar”, El Periodo Orientalizante. Actas del III Simposio Internacional de Arqueología de Mérida: Protohistoria del Mediterráneo Occidental, II (S. Celestino Pérez y J. Jiménez Ávila, eds.), Anexos de AEspA ,35, 1269-132.

Corzo, R. (1983), "Cádiz y la arqueología fenicia”, Anales de la Real Academia de bellas Artes de Cádiz, 1, 5-29.

(1992), "Topografía y ritual en la necrópolis de Cádiz”, Spal, 1, 263-292.

Christensen, P. (2007), Olympic Victor Lists and Ancient Greek History, Cambridge.

De Hoz, J. (1989), "Las fuentes escritas sobre Tartesos", Tartesos. Arqueología protohistórica del Bajo Guadalquivir. (M.E. Aubet Semmler, Coord.), AUSA, Sabadell, 25-43.

De la Bandera, M.L., Chaves, F., Ferrer, E. y Bernáldez, E. (1995), "El yacimiento tartésico de Montemolín”, Tartessos 25 años depués 1968-1993, Actas del Congreso Conmemorativo del V Symposium Internacional de Prehistoria Peninsular, Jerez de la Frontera, 315-332.

Docter, R.F., Niemeyer, H.G., Nijboer, A.J. y Van der Plicht, J. (2005), "Radiocarbon dates of animal bones in the earliest levels of Carthage", Oriente e Occidente: Metodi e discipline a confronto. Riflessioni sulla cronologia dell'età del ferro italiaba (a cura di Gilda Bartoloni e Filippo Delpino), Pisa-Roma, 557-575.

Docter, R., Chelbi, F., Telmini, B.M., Nijboer, A.J., Van der Plicht, J., Van Neer, W., Mansel, K. y Garsallah, S. (2008), "New Radiocarbon Ages from Carthage: Bridging the Gap between History and Archaeology", Beyond the Homeland Markers in Phoenician Chronology (C. Sagona, Ed.), Ancient Near East Studies, Supl. 28, Louvain-Paris-Dudley, 379-422.

Domínguez, A. (1993), La polis y la expansión colonial griega (siglos VIII-VI), Edit. Síntesis, Madrid.

(2012), "Gadir", Mitos y Arqueología en el nacimiento de las ciudades legendarias en la antigüedad (C. Fornis, ed.), Sevilla, 153-197.

(2014), "Fenicios y griegos en el Mediterráneo Occidental en el siglo VIII a.C.”, Fénicios e Púnicos por terra e por mar (A. M. Arruda, Ed.), Actas do VI Congreso Internacional de Estudos Fenícios e Púnicos, Vol. 1, Estudos e Mémorias 6, Uniarq, Lisboa, 418-427.

Escacena, J.L. (2001), "Fenicios a las puertas de 
Tartessos”, Complutum 12, 73-96.

Escacena, J.L. y García, F.J. (2012), "La Sevilla protohistórica", Hispaniae Urbes. Investigaciones arqueológicas en las ciudades históricas (J. Beltran y O. Rodríguez, Coords.), Serie Historia y Geografía, no 23, Sevilla, 763-814.

Fantalkin, I., Finkelstein, I. y Piasetzky, E. (2011), "Iron Age Mediterranean Chronology: a Rejoinder”, Radiocarbon, 53/1, 179-198.

Fernández, A. (2007), Tartessos desvelado: la colonización fenicia en el suroeste peninsular $y$ el origen del ocaso de Tartessos, Ed. Almuzara.

Fernández, A. y Rodríguez, A. (2005), “El complejo monumental del Carambolo Alto, Camas (Sevilla). Un santuario orientalizante en la paleodesembocadura del Guadalquivir”, Trabajos de Prehistoria 62/1, 111-138.

(2010), "El Carambolo, secuencia cronocultural del yacimiento. Síntesis de las intervenciones 20022005”, El Carambolo 50 años de un tesoro. (M.L. de la Bandera y E. Ferrer, Coords.), Universidad de Sevilla, 203-270.

Fernández, J. (1990), Tartesos y Huelva”, Huelva Arqueológica X/XI, I-III, Huelva.

Frede, S. (2000), Die Phönizischen Anthropoiden Sarkophage, Mainz.

Frutos, G. (1987), "Sobre la fecha de la fundación de Cartago y sus primeras proyecciones en Occidente", Habis, 18-19, 215-230.

Frutos, G. y Muñoz, A. (2008): "La incidencia antrópica del poblamiento fenicio-púnico desde Cádiz a Sancti-Petri”, Rampas, 10, 237-266.

García, E. (2005), "Consideraciones sobre la pyxis de la playa de Santa María del Mar (Cádiz)". Actas del III Simposio Internacional de Arqueología de Mérida: Protohistoria del Mediterráneo Occidental (S. Celestino y J. Jiménez Ávila, Eds.), Anexos de AEspA, 35, Mérida, 1323-1333.

(2007), En la orilla de Tartessos. Indígenas y fenicios en las tierras malagueñas. Siglos XI-VI a.C., Fundación Málaga, Málaga.

García y Bellido, A. (1963), "Hércules Gaditanus", AEspA, 63, 70-153.

(1968): España y los españoles hace dos mil años, según la geografía de Estrabón, Colección Austral, 515, Madrid.

Garrido, J. P. y Orta, M.E. (1970), Excavaciones en la necrópolis de la Joya $\left(1^{o}\right.$ y $2^{a}$ Campanas), Excavaciones Arqueológicas de España,
71. Madrid.

(1978): Excavaciones en la necrópolis de la Joya. Huelva II. (3 ${ }^{a}, 4^{a}$ y $5^{a}$ Campañas), Excavaciones Arqueológicas de España, Madrid.

Gavala y Laborde, J. (1927), "Cádiz y su bahía a través de los tiempos geológicos”, Boletín del Instituto Arqueológico y Minero, 50. Madrid, 230.

(1928), "Cádiz y su Bahía en el transcurso de los tiempos geológicos”, X Congreso de la Asociación Española para el progreso de las Ciencias, tomo VI, Madrid, 155-160.

(1936), Memoria explicativa de la Hoja 1.017, Madrid.

(1949), Hoja 1.018: El Rocío, Madrid.

(1952), Hoja 1.033: El Palacio de Doñana, Madrid.

(1973), El origen de las islas gaditanas, Instituto de Estudios Gaditanos, San Fernando-Cádiz.

Gener, J.M., Navarro, M.A., Pajuelo, J.M., Torres, M. y López, E. (2014a), "Arquitectura y urbanismo de la Gadir fenicia: el yacimiento del "Teatro Cómico" de Cádiz", Los fenicios en la Bahía de Cádiz; Nuevas investigaciones (M. Botto, Ed.), Collezione di Studi Fenici, 46, Roma, 14-50.

Gener, J.M., Jurado, G., Pajuelo, J.M. y Torres, M. (2014b), "El proceso de sacralización del espacio en Gadir: el yacimiento de la Casa del Obispo (Cádiz), Parte I. Los fenicios en la Bahía de Cádiz: Nuevas investigaciones (M. Botto, Ed.). Collezione di Studi Fenici, 46, Roma, 123155.

Gilboa, A. (2013), “À-propos Huelva: a reassesment of 'early 'Phoenicians in the West”. Tarteso. El emporio del metal (J.M. Campos y J. Alvar, Eds.), Ed. Almuzara, Córdoba, 311-342.

Gómez, F. (1996), Formas de ocupación del territorio durante los primeros siglos del I milenio a.C.: el Suroeste como marco de definición y contrastación, Tesis Doctoral, Universidad de Huelva, Huelva.

Gómez, F. y Campos, J.M. (2001), Arqueología en la ciudad de Huelva, Universidad de Huelva, Huelva.

González, R. y Ruiz Mata, D. (1999), "Prehistoria e Historia Antigua de Jerez”, Historia de Jerez de la Frontera. De los orígenes a época medieval (D. Caro, Ed.), Cádiz, 15-188.

González de Canales, F. (2004), Del Occidente mitico griego a Tarsis/Tartesos: fuentes escri- 
tas y documentación arqueológica, Biblioteca Nueva, Madrid.

Gonzalez de Canales, F., Serrano, S. y Llompart, J. (2004), El emporio fenicio precolonial de Huelva, ca. 900-770 a.C., Biblioteca Nueva, Madrid.

(2006), "Las evidencias más antiguas de la presencia fenicia en el sur de la Península" Mainake, XXVIII, 105-128.

(2009), "El inicio de la Edad del Hierro en el suroeste de la Península Ibérica y las navegaciones precoloniales y cuestiones en torno de las cerámicas locales de Huelva”, IV Encuentro de Arqueología del Suroeste (J. A. Pérez Macías y E. Romero Bomba, Eds.). Huelva, 648- 698.

(2010), "Tarshish and the United Monarchy of Israel", Anes, 47, 136-163.

(2017), "Producción de cerámicas griegas arcaicas en Huelva”, Archivo Español de Arqueología, 90, 125-145.

Gutiérrez, J.M., Reinoso del Río, M.C., Giles, F., Finlayson, C. y Saéz, A. (2013), "La cueva de Gorham (Gibraltar): un santuario fenicio en el confín occidental del Mediterráneo", Confines. El extremo del mundo durante la Antigüedad (F. Prados, I. García y G. Bernard, Eds.) Publicaciones de la Universidad de Alicante, 303-381.

Gruben, G. (1963), "Das archaische Didymaion”, Jahrbuch des Deutschen Archäologische Institut, 78,78-182.

Habibi, M. (1992), "La céramique á engobe rouge phénicien de Lixus", Actes du Colloque de Larache, Publicactions de l'École française de Rome, 166, Rome, 145-153.

Herrera, M.D. (1989), Tell Abu Hawan (Haifa, Israel). El estrato III, Tesis doctoral, Universidad de Cantabria, Santander.

Hunt, M. (1995), "El foco metalúrgico de Aznalcóllar, Sevilla. Técnicas analíticas aplicadas a la metalurgia del suroeste de la Península Ibérica”, Tartessos 25 años después, Actas del Congreso Conmemorativo del V Symposium Internacional de Prehistoria Peninsular, Jerez de la Frontera, 447-473.

2005): "Plata de Tartessos: producción y dispersión”. El Período Orientalizante. Vol. II (S. Celestino y J. Jiménez Ávila, Eds.), Actas del III Simposio Internacional de Arqueología de Mérida: Protohistoria del Mediterráneo Occidental, Anejos AEspA, XXXV, 1241-1248.
Jiménez, J. (200), La Toreutica Orientalizante en la Península Ibérica, Bibliotheca Praehistorica Hispana 26, RAH, Madrid.

Jiménez, J. (1971), Historia de Cádiz en la Antigüedad. Diputación Provincial de Cádiz.

Kletter, R. y Zitter, W, (2015), "Yahneh II. The "Temple Hill" Repository Pit", Orbis Biblicus et Orientalis, Series Archaeologia, 36, 28-139.

Krueger, M. y Brandherm, D. (2016), "Early Iron Age pottery in south-western Iberia -archaeology and chronology", Networks of Trade in raw materials and technological innovations in Prehistory. An Archaemetric Approach, Proceedings of the XVIII UISPP Congress, Vol. 12. (D. Delfino, P. Piccardo y J. Carlos Baptista, Eds.), Archaeopress Publishing Ltd, Oxford, 95103

Kukahn, E. (1951), "El sarcófago sidonio de Cádiz”, $A E \operatorname{spA}$, XXIV, 23-24.

Lancel, S. (1994), Cartago, Critica, Barcelona.

Laporte, J.P. (2004), "Siga et l'île de Rachgoun", L'Africa romana, Atti del XVI convegno di studio. Rabat 2004,. Carocci editore, 25322596.

Lipinski, E. (1984), "Vestiges phéniciens d'Andalousie", Orientalia Lovaniensia Periodica, 15, Leuven, 84-86.

López, J.J., Bueno, P., Ruiz, J.A., Prada, M. (1996), Tartesios y fenicios en Campillo, El Puerto de Santa María, Cádiz. Una aportación a la cronología del Bronce Final en el Occidente de Europa, El Puerto de Santa María.

López, J.J., Ruiz, D. y Ruiz, J.A. (2008), "El entorno de la Bahía de Cádiz a fines de la Edad del Bronce e inicios de la Edad del Hierro", Revista Atlántica-Mediterránea de Prehistoria y Arqueología Social, 10, 215-236.

López, J.L., Ferjaoui, A., Mederos, A., Martínez, V.M. y Jerbania, I. Ben (2016), "La colonización fenicia en el Mediterráneo Central: nuevas excavaciones arqueológicas en Utica (Túnez), Trabajos de Prehistoria 73/1, 68-69.

López, F. (1996), "Los enclaves fenicios en el África noroccidental: del modelo de las escalas náuticas al de colonización con implicaciones productivas”, Gerión,14, 251-288.

López, F. y Mederos, A. (2008), La factoría fenicia de la isla de Mogador y los pueblos del Atlas, Canarias Arqueología, Monogr. 3, Tenerife.

Maass-Lindemann, G. (1992), “A comparison of 
the Phoenician pottery of Lixus with the West Phoenician of Spain”, Actes du Colloque de Larache, Publications de l'École française de Rome, 166, 175-180.

Manning, L. (2010), Colonial Religion and Indigenous Society in the Archaic West-Mediterranean c. 750-400 B.C., Disertation, Stanford University.

Marín, M.C. (1983), "La religión fenicia en Cádiz”, Cádiz en su Historia, Cádiz, 5-41.

Marín, M.C. y Jiménez, A.M. (2011a), "El Kronion de Gadir: una propuesta de análisis", Cultos y ritos de la Gadir fenicia (M.C. Marín Ceballos, coord.), Cádiz, 222-245.

(2011b),"El capitel protoeólico de Cádiz”, Cultos y ritos de la Gadir fenicia (M.C. Marín Ceballos, Coord.), Cádiz, 120- 128.

Mccullough, L. (2007), Dimensions of the temple: the temple account in 1 Kings 5-9 compared with Ancient Near Eastern temple paradigms". Thesis Masters of Arts. Nashville, Tennessee.

Maya, R., Jurado, G., Gener, J.M., López, E., Torres, M. y Zamora, J.A. (2014), "Nuevos datos sobre la posible ubicación del Kronion de Gadir: Las evidencias de época fenicia arcaica”, Los fenicios en la Bahía de Cádiz: Nuevas investigaciones. (M. Botto, Ed.), Collezione di Studi Fenici, 46, 157-180.

Maya, R., Jurado, G., Gener, J.M., López, E., Torres, M., y Zamora, J.A. (2014), "Nuevos datos sobre la posible ubicación del Kronion de Cádiz: las evidencias de época arcaica”, Los fenicios en la Bahía de Cádiz. Nuevas investigaciones (M. Botto, Ed.), Collezione di Studi Fenici, 46, 156- 180.

Mederos, A. (1996), "La cronología absoluta de Andalucía Occidental durante la prehistoria reciente (6100-850 a.C.)", Spal 5, 45-86.

(2005), "La cronología fenicia entre el Mediterráneo Oriental y el Occidental", Anejos de AEs$p A$, XXXV, 305-346.

(2006a), "Los inicios de la presencia fenicia en Málaga, Sevilla y Huelva”, Mainake, XXVII, 129176.

(2006b), "Fenicios en Huelva, en el siglo X a.C., durante el reinado de Hiram de Tiro", Spal, 15, 167-188.

(2015), "La cronología de Huelva fenicia”, Fenícios e Púnicos, por terra e mar, Actas del VI Congreso Internacional de estudos Fenícios e Púni- cos, Estudos e Memorias, Lisboa, 482-495.

Mederos, A. y Ruiz, L. (2006), "Los inicios de la presencia fenicia en Málaga, Sevilla y Huelva”, Mainake, 28, 120-176.

Menanteau, L. (1976), "Les anciens etiers de la rive gauche des marismas du Guadalquivir: un example d'utilisation des données archéologiques en géomorphologie litorale", Mélanges de la Casa de Velázquez, 14, 35-72

(1978), "Les marismas du Guadalquivir: apport de la teledetection et de l'archéologie a la reconstitution du paysage", Caesarodumum, 13, 178.

Menanteau, L., Vanney, J.R. y Guillemot, E.(1989), Mapa Fisiográfico del litoral Atlántico de Andalucía-M.F. Rora-La Barrosa (Bahía de Cádiz). M.F O5: Cabo Rocha-Ensenada de Bolonia, Sevilla.

Momigliano, A. (1984), La historiografía griega, Crítica, Barcelona.

Moscati, S. (1996), "La Grande Cadice dei Fenici”, RAL, ser. IX, 1-22.

Muñoz, A.(1995-96), "Secuencia histórica del asentamiento fenicio-púnico de Cádiz: Un análisis crono-espacial tras quince años de investigación arqueológica”, Boletín del Museo de Cádiz, VII, 77-105.

(1999): "Gadir en el Castillo de Doña Blanca: análisis crítico de una hipótesis". Revista de Historia de El Puerto, 23, 55-64.

Mustafa, B. (2013), "New thypogeal Tomb with a "Phoenician" aantropoid sarcaphagi on Tartus, Syrian coast", CuPAUAM, 39, 113-122.

(2014), La imagen de la realeza en la costa de Levante en época persa. Arqueología de los sarcófagos antropomorfos fenicios, Tesis Doctoral, Universidad de Granada.

(2015), "Nuevo sarcófago antropoide fenicio en la costa de Siria", ArqueoWeb, 16, 21-31.

(2016), "The anthropoid sarcophagi of Amrit/Arad (Syria): a study of acrchaeological contextualization", Scientific Culture, 2.2, 1-8.

Niemeyer, H.G. (1979), “A la búsqueda de Mainake: el conflicto entre los testimonios arqueológicos y escritos", Habis, 10-11, 279-302.

Nigro, L. (2014), "An absolute Iron Age Chronologies of the Levant and Mediterranean", Rosapat, 11, 261-269.

Nijboer, A.J. (2016), "Is the entangling of events in the Mediterranean around 770-60 B.C. in the conventional absolute chronology (CAC) a reality or a construct?, Acts of the Confe- 
rence Contextualizing Early Colonization Archaeology, Sources, Chronology and Interpretative Models between Italy and the Mediterranean, vol. 1., Papers of the Royal Netherlands in Rome, vol 64, 35-47.

Nijboer, A. J. y Van der Plicht, J. (2006), “An interpretation of the radiocarbon determinations of the oldest indigenous- Phoenician stratum thus far, excavated at Huelva, Tartessos (southwest Spain)", BABesch, 81, 31-36.

Niveau de Villedary, A.M. (2008), "Estado de la cuestión y nuevas perspectivas de la arqueología punica en la Península Ibérica: El caso de la Bahía de Cádiz”, Nuevas perspectivas II. La arqueología fenicia y púnica en la Península Ibérica (J.P. Vita y J.A. Zamora, Eds.), Cuadernos de Arqueología Mediterránea, 18, 81-127. (2010), "Deconstruyendo paradigmas. Una (re)visión historiográfica crítica al modelo interpetativo tradicional del Cádiz fenicio-púnico a la luz de los nuevos datos", Mainake, XXXII (I), 619-671.

(2014), "De colonia a ciudad. Algunos apuntes sobre la situación y naturaleza de la ciudad de Gadir", In Amicitia. Miscel-lània en homenatge a Jordi H. Fernández (C. Ferrando y B. Costas, Eds.), Treballs del Museu Arqueólogic d'Eivissa i Formentera, 72, Eivissa, 485-502.

Núñez, F.J. (2008), "Western challenges to east Mediterranean chronological frameworks", $A$ New Dawn for the Dark Ages? Shifting Paradigms in Mediterranean Iron Age Chrono$\log y$, Bar International Series, 1871, 3-27.

(2011), "Tyre -Al Bass. Potters and Cemeteries", Ceramics of the Phoenician-Punic World: Collected Essays (C. Sagona, Ed.), Ancient Near East, Suppl. 36, Leuven-Paris-Walpole, M.A., 277-296.

(2014), "Brief Commentary on the 14C dates obtained in funerary contexts A-Bass", BAAL. Hors Séries IX, cap. 2, 535-538.

(2016), "Considerations arounda polarized Mediterranean Iron Age Chronology". Contexts of Early Colonization (L. Donnellan. V. Nizzo, G.J. Burgers, Eds.), Papers of the Royal Netherland Institut in Rome, 64, 73-85.

Oller, M. (2013), "Griegos e indígenas en Empórion (siglos VI-IV a.C.): un estado de la cuestión”, Contactos de poblaciones y extranjería en el mundo antiguo, Faventia. Supplementa 2,187202.
Pellicer, M. (1963), Excavaciones en la necrópolis púnica "Laurita” del Cerro de San Cristóbal (Almuñécar, Granada), Excavaciones Arqueológicas de España, 17, Madrid.

Pemán, C. (1959), "El capitel de tipo protojónico de Cádiz”, AEspA, XXXII, 99-100, 58-70.

Peralta, E. (2009), "La II Guerra Púnica”, Historia militar de España (H. O’Donell y Duque de Estrada, Dir.). I. Prehistoria y Antigüedad (M. Almagro-Gorbea, Coord.), Ediciones del Laberinto-Ministerio de Defensa, Madrid, 174-197.

Perdigones, L., Muñoz, A. y Pisano, G. (1990), La necrópolis fenicio-púnica de Cádiz. Siglos VI-IV a.C., Studia Punica 7, Roma.

(1991): "Hallazgos recientes en torno al santuario de Melkart en la isla de Sancti Petri (Cádiz)", Atti del II Congresso Internazionale di Studi Fenici e Punici, Vol. 3., Roma, 1119-1132.

Pilkington, N. (2013), An Archaeological History of Carthaginian Imperialism, Tesis doctoral, Columbia University.

Ponce, F. (1983), "Consideraciones en torno a la ubicación del Cádiz Fenicio", Anales de la Universidad de Cádiz, II, 99-122.

(1985), "Consideraciones en torno a la ubicación del Cádiz fenicio", Anales de la Universidad de Cádiz 2, 99-121.

(2000), "Sobre la ubicación del Cádiz fenicio", $A c$ tas del IV Congreso Internacional de Estudios Fenicios y Púnicos, Vol. II, Servicio de Publicaciones de la Universidad de Cádiz, 905914.

Prados, F. (2001), "Pasado, presente y futuro de las investigaciones sobre el mundo púnico: una revisión ante el nuevo milenio", CuPAUAM, 27, 63-78.

Quintero, P. (1912), Antigüedades de Punta de Vaca. Guía de Cádiz, Cádiz.

(1914), "Necrópolis ante-romana de Cádiz", Boletín de la Sociedad Española de Excursiones, XXII, 81-107 y 161-175.

(1916), Excavaciones en Punta de la Vaca (Cádiz), Junta Superior de Excavaciones y Antigüedades. Memoria, 5, Madrid.

(1917a), "Excavaciones en Punta de la Vaca y en Puerta de Tierra (ciudad de Cádiz), Junta Superior de Excavaciones y Antigüedades. Memoria 12, Madrid.

(1917b), Cádiz, primeros pobladores: hallazgos arqueológicos, Cádiz.

(1929), Excavaciones en Cádiz. Memoria de las 
excavaciones practicadas en 1928, Junta Superior de Excavaciones y Antigüedades. Memoria 99, Madrid

Rainey, S. (2004), The Nature of Carthaginian Imperial Activity: Trade, Settlement,

Conquest and Rule, Tesis doctoral, University of Canterbury.

Ramírez, J.R. (1982), Los primitivos núcleos de asentamientos en la ciudad de Cádiz, Cádiz.

Riera, R. (2015), Relaciones militares y diplomáticas de Cartago en el Mediterráneo Occidental (410-221 a.n.e.), Tesis doctoral, Universidad Autónoma de Barcelona.

Rodríguez, P. (2002), "Ecos de la Grecia Antigua en la Málaga romana”, Real Academia de Bellas Artes de san Telmo. Anuario, 41-52.

Roselló, E. y Morales, A. -Coords.- (1994), Castillo de Doña Blanca: archaeo-environmental investigations in the Bay of Cadiz (750-500 B.C.), B.A.R. International Series, 593, Oxford.

Ruiz-Gálvez, M. (2009), “¿Qué hace un micénico como tú en un sitio como éste? Andalucía entre el colapso de los palacios y la presencia semita”, Trabajos de Prehistoria, 66.2, 93-118.

Ruiz, J.A., Pérez, E., López, J.J. y Monclova, A. (1990), "El yacimiento protohistórico de Las Beatillas (El Puerto de Santa María)", Revista de Historia de El Puerto, 4, 11-38.

Ruiz, J.A. y López, J.J. -Eds.- (2001), Formaciones sociales agropecuarias en la Bahia de Cádiz. 5000 años de adaptación ecológica en la Laguna del Gallo, El Puerto de Santa María. Memoria arqueológica de Pocito Chico, 1997-2001, Sanlúcar de Barrameda.

Ruiz Mata, D. (1981): "El poblado metalúrgico de época tartésica de S. Bartolomé (Almonte, Huelva)", Madrider Mitteilungen, 22, 150-170.

(1982), Las cerámicas del Bronce Final tartésico, Tesis doctoral, Universidad Autónoma de Madrid.

(1989), "Huelva: un foco temprano de actividad metalúrgica durante el Bronce Final", Tartessos (M.E. Aubet, Ed.), AUSA, Sabadell-Barcelona, 209-243.

(1994), “Territorio y proceso histórico de El Puerto de Santa María (aproximadamente desde el 3000 hasta el siglo III a.n.e.)", Revista de Historia de El Puerto, 12, 11-50.

(1995), "Referencia historiográfica sobre el castillo de Doña Blanca (El Puerto de Santa María, Cádiz)”, La Antigüedad como argumento II: historiografía de arqueología e historia antigua de Andalucía (F. Gascó y J.L. Beltrán, Coords.), Sevilla, 153-176.

(1998), "Fenicios en el sur peninsular; sucinta reseña historiográfica y propuesta de objetivos de investigación en los albores del año 2000”, $A r$ bor, CLXI, 413-139.

(1999),"La fundación de Gadir y el Castillo de Doña Blanca: contrastación textual y arqueológica", Complutum, 10, 279-317.

(1999), "Siempre resulta positivo precisar los datos, si son necesarios para explicar la Historia”, Revista de Historia de El Puerto, 23, 65-75.

(2016), "Las ciudades fenicias del Castillo de Doña Blanca y Cádiz durante el siglo VIII a.C. Mi visión actual según los datos recientes arqueológicos”, $R S F$, XLIV, 305-318.

Ruiz Mata, D., Blázquez, J.M., Martin de la Cruz, J.C. (1981), "Excavaciones en el Cabezo de San Pedro (Huelva). Campaña de 1978”, Huelva Arqueológica V, 149-316.

Ruiz Mata, D., López, J.J. y Bueno, P. (2004), “La Laguna del Gallo: un modelo de poblamiento y proceso histórico de la prehistoria reciente en la Bahía de Cádiz (El Puerto de Santa María)", Actas do II Encontro de Arqueología do Sudoeste Peninsular, Faro, 81-103.

Ruiz Mata, D. y Fernández, J. (1987), El yacimiento metalúrgico de época tartésica de san Bartolomé de Almonte (Huelva), Huelva Arqueológica VIII, Vols. I-II, Huelva.

Ruiz Mata, D. y Pérez, C.J. (1995), El poblado fenicio del Castillo de Doña Blanca (El Puerto de Santa María, Cádiz), Biblioteca de Temas Portuenses 5, El Puerto de Santa María.

Ruiz Mata, D., Pérez, C.J. y Gómez, V. (2014), "Una nueva zona fenicia de época arcaica en Cádiz: el solar de la "calle Ancha”, n 29", Los fenicios en la bahía de Cádiz: Nuevas investigaciones (M. Botto, Ed.), Collezione di Studi Fenici 46, Roma, 83-122.

Sánchez, V.M., Galindo, L., Juzgado, M. y Dumas, M. (2012), "El asentamiento fenicio de la Rebadanilla a finales del siglo IX a.C.”, Diez años de arqueología fenicia en la provincia de Málaga (2001-2010), (E. García Alonso, Ed.), Consejería de Cultura y Deportes-Dirección General de BB.CC y de Instituciones Museísticas, 67-85, Sevilla.

Santiago, J. (2016), "La identidad nacional y la religión. Un marco analítico aplicado al País vasco 
y Quebec", Papeles del CEIC, 2, 1-24.

Sarmentero, Ma M. (2015), Aportaciones a la posible ubicación de Mainake: consideraciones económicas derivadas de ello. La ceca de Málaga, Tesis doctoral, Uned, Madrid.

Schubart, H. (1984), "El asentamiento fenicio occidental en la desembocadura del río Vélez. Excavaciones de 1971", Noticiario Arqueológico Hispánico, 19, 39-205.

Schubart, H. y Maass-Lindemann, G. (2017), Morro de Mezquitilla. Die Phönizische-Punische Niederlassung an der Algarrobo-Mündung, Madrider Baiträge 33, Reichert Verlag Wiesbaden.

Sierro, F.J. y Zazo, C. (2004), "Cuenca del Guadalquivir”,. En: Geología de España (J.A. Avera, Ed), Sociedad Geológica de España-Instituto Geológico y Minero de España, Madrid, 543550.

Torres, M. (1996), "La cronología de los túmulos A y B de Setefilla. El origen del rito de la cremación en la cultura tartésica”, Complutum, 7 , 147-162.

(1998), "La cronología absoluta europea y el inicio de la colonización fenicia en Occidente. Implicaciones cronológicas en Chipre y en el Próximo Oriente", Trabajos de Prehistoria, 9, 49-60.

(2008), "The Chronology of the Late Bronze Age in Western Iberia and the beginning of the Phoenician colonization in the Western Mediterranean", A New Dawn for the dark Age? Shifting Paradigmas in Mediterranean Iron Age Chronologies, Bar International Series, 1871, 135-147.

(2010), "Sobre la cronología de la necrópolis fenicia arcaica”, Las necrópolis de Cádiz. Apuntes de arqueología gaditana en Homenaje a J.F. Sibón (A.N. Niveau de Villedary y V. Gómez Fernández, Eds.), Servicio de Pubicaciones de la Diputación de Cádiz- Servicio de Publicaciones de la Universidad de Cádiz, Cádiz, 31-67.

Torres, M., López, E., Gener, J.M., Navarro, M.A. y Pajuelo, J.M. (2014), “El material cerámico de los contextos fenicios del "Teatro Cómico" de Cádiz: un análisis preliminar”, Los fenicios en la Bahía de Cádiz: Nuevas investigaciones (M. Botto, Ed.). Collezione di Studi fenici, 46, Roma, 51-82.

Tortorelli, $\mathrm{M}^{\mathrm{a}}$ (2015), "Identidad y mito de la autoctonía de la Grecia Antigua. La tierra, los hijos de la tierra”, Anales de Historia Antigua,
Medieval y Moderna, 49, 5-14.

Tsirkin, Y.B. (2013), "Las fundaciones de Cartago y Massalia. Algunas analogías”, Polis, 25, 163-181.

Tuzi, S. (2002), Le Colonne e il tempio de Salomone, Gangemi Editore, Roma.

Van de Plicht, J., Bruins, H.J. y Nijboer, A.J. (2009), "The Iron Age around Mediterranean: a High Chronology Perspective from the Groningen Radiocarbon Database", Radiocarbon, 51, 213-142.

V.VAA. (2000), Un futuro para la memoria. Sobre la administración y el disfrute del Patrimonio Histórico Español (J. Leguina y E. Baquedano, Eds.), Psoe, Madrid.

V.VAA (2010), Las necrópolis de Cádiz. Apuntes de arqueología gaditana en homenaje a J.F. Sinón Olano (A.M. Niveau deVilledar y V. Gómez Fernández, Eds.), Servicio de Publicaciones UCA- Servicio de Publicaciones Diputación Provincial de Cádiz.

Zamora, J.A. (2006), "La "ciudad nueva”. La fundación de ciudades en el mundo fenicio-púnico", Nuevas ciudades, nuevas patrias. Fundación y relocalización en Mesoamérica y el Mediterráneo Antiguo (M. Josefa Iglesias Ponce de León, Rogelio Valencia Rivera y Andrés Ciudad Ruiz, Eds.), Publicaciones de SEEM, 8, 331-368. 